UNIVERSIDADE DE SÃO PAULO

INSTITUTO DE PSICOLOGIA

Associação entre Genótipo de Risco para Retinopatia Diabética

Proliferativa e Disfunção Visual Precoce

LIVIA SOLEDADE DE MORAES REGO

SÃO PAULO

2016. 


\section{ASSOCIAÇÃO ENTRE GENÓTIPO DE RISCO PARA RETINOPATIA DIABÉTICA PROLIFERATIVA E DISFUNÇÃO VISUAL PRECOCE}

Dissertação apresentada ao Instituto de Psicologia da Universidade de São Paulo como parte das exigências para a obtenção do título de Mestre em Ciências.

Área de Concentração: Psicologia Experimental.

Orientadora: Profa. Dra. Mirella Gualtieri.

SÃO PAULO

2016. 


\section{AUTORIZO A REPRODUÇÃO E DIVULGAÇÃO TOTAL OU PARCIAL DESTE TRABALHO, POR QUALQUER MEIO CONVENCIONAL OU ELETRÔNICO, PARA FINS DE ESTUDO E PESQUISA, DESDE QUE CITADA A FONTE.}

Catalogação na publicação

Biblioteca Dante Moreira Leite

Instituto de Psicologia da Universidade de São Paulo

Rego, Livia Soledade de Moraes.

Associação entre genótipo de risco para retinopatia diabética proliferativa e disfunção visual precoce. / Livia Soledade de Moraes Rego; orientadora Mirella Gualtieri. -São Paulo, 2016.

$142 \mathrm{f}$.

Dissertação (Mestrado - Programa de Pós-Graduação em Psicologia. Área de Concentração: Psicologia Experimental) Instituto de Psicologia da Universidade de São Paulo.

1. Diabetes Mellitus, 2. Retinopatia diabética 3. Eritropoietina 4. Poliformismo gênico 5. Neurociência da visão I. Título.

RJ420.D5 
Candidato (a): LIVIA SOLEDADE DE MORAES REGO.

Título da Dissertação: ASSOCIAÇÃO ENTRE GENÓTIPO DE RISCO PARA RETINOPATIA DIABÉTICA PROLIFERATIVA E DISFUNÇÃO VISUAL PRECOCE. Orientador (a): Profa. Dra. MIRELLA GUALTIERI.

A Comissão Julgadora dos trabalhos de Defesa da Dissertação de Mestrado, em sessão pública realizada a ............... , considerou o(a) Candidato (a):
( ) Aprovado(a)
( ) Reprovado(a)

\section{BANCA EXAMINADORA:}

Examinador(a):

Assinatura:

Nome:

Instituição:

Examinador(a):

Assinatura:

Nome:

Instituição:

Examinador(a):

Assinatura:

Nome:

Instituição: 
Dedico especialmente este trabalho a todos os profissionais e pacientes da Liga de Controle do Diabetes Mellitus do HCFMUSP, que contribuíram com amizade e dedicação para que este trabalho pudesse surgir. 


\section{AGRADECIMENTOS}

Eis a finalização de um trabalho escrito a duas mãos e muitos corações! Muitos contribuíram para que esta dissertação existisse e assim, creio que nestas poucas palavras não haverá a possibilidade de agradecer a todos.

Agradeço a CAPES pelo fornecimento da bolsa de Mestrado.

Gostaria de agradecer à Profa. Dra. Mirella Gualtieri pela oportunidade oferecida e pela orientação. Gostaria também de agradecer à Prof. Dra. Dora Fix Ventura pela oportunidade no LABVIS. Além disto, agradeço às Profas. Dras. Christina Joselevitch e Daniela Maria de Oliveira Bonci por todo o aprendizado, conversas e ajuda na confecção deste trabalho. Gratidão minha também ao Instituto de Ensino e Pesquisa (IIEP) do Hospital Israelita Albert Einstein, pela utilização do Laboratório de Genética para sequenciamento das amostras.

Agradeço ao Prof. Dr. Marcelo Fernandes da Costa, por seguir meus passos desde a graduação, por todas as dicas, conversas e por uma participação tão enriquecedora na banca de Qualificação. Da mesma forma, agradeço à Profa. Dra. Mônica Melo pelas sugestões tão importantes e cuidadosas na Banca de Qualificação.

Amigos do LABVIS, muitíssimo obrigada pelos cafés, apoio durante os experimentos e companhia sempre presente! Obrigada também pelos pacientes e controles que participaram desta pesquisa, oferecendo o seu tempo e seu sangue (literalmente!) na coleta de dados.

Gostaria também de agradecer imensamente às pessoas que coletaram alguns dados ou que contribuíram com a parte experimental deste trabalho: Profa. Dra. Daniela Bonci, Profa. Dra. Einat Hauzman, Msc. Viviane Mantovani, Doutoranda Valéria Duarte Garcia, Estagiários Stephen Joseph Juel e Victoria Katarine Honneth e Sushma Kalava. A ajuda de vocês foi fundamental para que tal pesquisa pudesse acontecer. Muito obrigada também pelo apoio nos mais diversos momentos da realização deste trabalho. Além disto, minha gratidão eterna aos médicos oftalmologistas Prof. Dr. Francisco Max Damico, Profa. Dra. Kallene Summer Moreira Vidal e Dr. Ronaldo Yuiti Sano pelo exame oftalmológico dos pacientes desta pesquisa. Tal empreendimento custou tempo precioso para vocês e sou grata por terem contribuído de maneira tão importante. Além disto, agradeço às Enfs. Amanda Martins Bastos e Mariana Fernandes Yamamoto pela coleta de sangue dos pacientes desta pesquisa e por todo o apoio nesta jornada. Drs. Mirella Barboni e Balasz Nagy, muitíssimo obrigada por todo o 
apoio e carinho durante a coleta de dados desta pesquisa e muito obrigada por me salvarem tantas vezes durante a coleta de dados. Mari, muito obrigada por me apoiar em momentos cruciais desta pesquisa, por me ajudar em diversas etapas deste trabalho com tanto carinho e empenho.

Minha gratidão incondicional ao Prof Dr. Simão Augusto Lottemberg, que me recebeu de braços e coração abertos, bem como aos profissionais da Liga de Controle do Diabetes, pelos pacientes compartilhados, por todos os ensinamentos e amizade que permearam este trabalho.

Agradeço também ao Prof. Dr. Alberto Olavo Advíncula Reis e amigos do LASAMEC por todo o apoio e carinho de longa data e por despertarem o desejo de sempre continuar crescendo na área de pesquisa. Da mesma forma, agradeço ao Prof. Horácio Souza e equipe de ensino do Objetivo por todas as oportunidades dadas, pela confiança sempre depositada em mim e por me ajudarem (até hoje!) nos primeiros passos que culminaram nesta dissertação. Thanks to Stephen Joseph Juel for teaching me so carefully how to do a PCR and other procedures in Molecular Biology and all support to me! Thanks for your precious friendship and good talkings.

Gostaria também de agradecer imensamente aos amigos Thaís Ananda, Clayton Silva e às "chicas" Tania Torejón e Janeth Quispe, por estarem sempre presentes, nos bons e maus momentos, dividindo experiências, pelo apoio e amizade. Meus especiais agradecimentos à Priscilla Facanti, nova e tão importante amiga, sempre presente e compartilhando as agruras dos novos recomeços. Obrigada também a Diego Decleva, por toda amizade, carinho e ajuda incondicional sempre (além das guloseimas e sucos compartilhados, rsrsrs). Muito obrigada pelos ótimos conselhos, apoio e excelentes ideias, sempre! Da mesma forma, agradeço a Felipe Galante, pela presença sempre amiga, pelas conversas infinitas e pelo apoio incondicional em tudo! Agradeço também à Aline Goto, pelos momentos de carinho e amizade, de longa data. Da mesma forma, agradeço à amizade, ao carinho e apoio de André Líber, Amanda Bastos, Luíse Garcia, Luiz Cláudio Baran, Vivi Mantovani e Vítor Corredor, por estarem sempre presentes. Da mesma forma, meus agradecimentos à Taninha e à Adriana, pela amizade, apoio, por todo cuidado e dedicação.

Agradeço aos amigos, colegas de trabalho da Clínica de Psicologia e Nutrição Ser e Se Conhecer, por todo o aprendizado e companhia. Especialmente aos amigos Milena 
Degasperi, Eric Heibel e Gustavo Aguiar, pela oportunidade e aprendizado, pela confiança que depositam e mim e especialmente, pela amizade tão especial. Tenho a sorte de ter vocês na minha vida.

Agradeço à minha família, minha avó Elizabetha e minha mãe Silvia Wengorsky, por todo o sacrifício, abnegação e apoio incondicional em todos os projetos da minha vida, desde que eu mesma era só um projeto! 
"Love looks not with the eyes, but with the mind, and therefore is winged Cupid painted blind."

(William Shakespeare) 
APOIO FINANCEIRO

Bolsa de Mestrado CAPES

Projeto regular FAPESP \# 2009/06026-6

Projeto CAPES/PROCAD \# 182/2007 


\section{RESUMO}

Rego, L.S.M. Associação entre genótipo de risco para Retinopatia Diabética Proliferativa e disfunção visual precoce. [Dissertação (Mestrado em Ciências)]. São Paulo: Instituto de Psicologia, Universidade de São Paulo, 2016.

Alterações macro e microvasculares ocorrem no Diabetes Mellitus (DM). A Retinopatia Diabética (RD) é uma complicação bem prevalente do DM e resulta de microangiopatia generalizada no tecido retiniano que, em diferentes estágios da doença, se observa como edema local, exsudatos, formação de neovasos e hemorragias, sendo a principal causa de cegueira na faixa etária de 20 a 74 anos. Alguns fatores angiogênicos são apontados como possíveis mediadores no desenvolvimento das alterações microvasculares no DM. Dentre eles, a Eritropoietina (EPO), hormônio glicoproteico, possui expressão mediada por alelos específicos do gene EPO. Determinados perfis genéticos para três SNPs-single nucleotide polymorphisms do gene EPO (rs1617640, rs507392, rs551238) encontram-se associados com maiores concentrações de EPO no humor vítreo de pacientes diabéticos com RD, o que pode ser indicativo da relação entre determinado genótipo de risco (TTA) e o desenvolvimento de tal comorbidade. O presente trabalho pretendeu investigar a associação entre o genótipo considerado de risco para o desenvolvimento de RD e alterações funcionais na visão de cores de pessoas com diagnóstico de DM. Tal estudo contou com uma amostra de 95 diabéticos (49 mulheres e 46 homens, média de idade: 48,33 anos; DP: 16,90), com um total de 31 DM tipo 1 e 64 tipo 2 e 114 controles (73 mulheres e 41 homens, média de idade: 38,38 anos; DP: 12,81). Foi realizada avaliação através de teste psicofísico (Cambridge Colour Test - CCT), que visou medir o limiar de discriminação nos três eixos de confusão de cores e sequenciamento genético, a partir de amostras de sangue. Para os diabéticos, no eixo de confusão protan, os resultados mostraram uma piora de desempenho para o genótipo TTA/GCC ( $\mathrm{p}=0,048)$, com relação aos controles. No eixo de confusão deutan, não houve diferença para qualquer dos genótipos ( $\mathrm{p}=0,0207)$, enquanto que para o eixo tritan, o genótipo TTA/GCC esteve associado a uma piora de desempenho $(\mathrm{p}=0,014)$. Para os controles, não houve diferença entre os genótipos. Assim, os resultados mostraram uma piora na visão de cores de pacientes DM, associada ao haplótipo TTA/GCC.

Palavras-chave: Diabetes Mellitus, Retinopatia Diabética, Eritropoietina, Polimorfismo Gênico, Neurociência da Visão. 


\begin{abstract}
Rego, L.S.M. Association between risk genotype for Proliferative Diabetic Retinopathy and early visual dysfunction. [Dissertation (Master in Sciences)]. São Paulo: Instituto de Psicologia, Universidade de São Paulo, 2016.
\end{abstract}

Diabetic Retinopathy (DR), a prevalent complication of diabetes, is the leading cause of blindness among those aged 20-74 years. Micro and macrovascular changes occur in Diabetes Mellitus (DM) with DR being the most common among these vascular complications, resulting in generalized retinal microgangiopathy. At different stages of the disease, localized edema, exudates and hemorrhages occur. Several pro-angiogenic factors have been suggested as possible mediators in the development of these microvascular changes. Among them is erythropoietin (EPO), a glycoprotein hormone whose expression is mediated by specific alleles of the EPO gene. Specific genetic profiles for three single nucleotide polymorphisms (SNPs) in the EPO gene (rs1617640, rs507392, rs551238) are associated with larger EPO concentrations in the vitreous humor of diabetic patients with RD. This association indicates a possible relationship between the identified genotypes (TTA) and the comorbidity's development. This work aimed to investigate the association between genotypes considered at risk for the development of DR and functional changes in color vision among individuals diagnosed with DM. Thus, this study included a sample of 95 diabetic patients (49 women and 46 men, average age: 48.33 years; SD: 16.90), with a total of $31 \mathrm{DM}$ type 1 and 64 type 2 and 114 controls (73 women and 41 men, average age: 38.38 years; SD: 12.81). Evaluation was performed using a psychophysical test (Cambridge Colour Test -CCT), to measure the discrimination threshold in three-color confusion axes in addition to genetic sequencing. In the protan axis of confusion color, performance among diabetics with the TTA/GCC genotype was significantly lower $(p=0.048)$ than those in the control group. The results showed a poorer performance among those with the TTA / GCC genotype $(\mathrm{p}=0.048)$, compared to controls. In deutan axis confusion, there was no difference among any of the genotypes $(\mathrm{p}=0.0207)$, while for the tritan axis, the TTA / GCC genotype was associated with a poorer performance $(\mathrm{p}=0.014)$. For the controls, there was no difference between genotypes. Thus, the results showed a worsening in color vision among DM patients associated with TTA / GCC haplotype.

Keywords: Diabetes Mellitus, Diabetic Retinopathy, Erythropoietin, Gene Polymorphism, Visual Neuroscience. 


\section{LISTA DE ILUSTRAÇÕES-}

Figura 01- Prevalência da DM (em milhões de pessoas) nos dez países com o maior número de casos da doença, entre 20 e 79 anos de idade, em números absolutos.

Figura 02- Tomografia de Coerência Óptica (OCT) em OD de paciente do sexo masculino de 57 anos de idade, com RDP e edema macular.

Figura 03- Imagem ilustrando um fundo de olho em um quadro de RDP.

Figura 04-Imagem ilustrando um fundo de olho imediatamente após a realização de fotocoagulação a laser.

Figura 05- Esquema anatômico de uma retina normal e com RDP.

Figura 06- Imunohistoquímica com Peanut agglutinin (PNA) em retinas de ratos diabéticos e controles.

Figura 07- Ativação de células da glia em rato com quatro semanas de diabetes induzida.

Figura 08- Diagrama de regulação de eritropoiese por feedback hormonal.

Figura 09- Experimento de Newton demonstrando a decomposição da luz solar no espectro de cores fundamentais.

Figura 10- Espectro Visível da luz.

Figura 11- Cones (em azul) e bastonetes (em verde) presentes em retina murina.

Figura 12- Densidade de cones e bastonetes em relação à distância da fóvea.

Figura 13- Curva de absorção espectral para os três tipos de cone e para os bastonetes encontrados na retina de humanos tricromatas.

Figura 14- Sistema de Aparência de Cores de Munsell.

Figura 15- Representação do Diagrama CIE de 1976. 
Figura 16- Os três eixos de confusão de cores do protocolo Trivector, distribuídos nas coordenadas do Diagrama CIE.

Figura 17- Exemplo de Estímulo empregado no CCT.

Figura 18- Gel de agarose 10\%, fotografado sob iluminação ultravioleta.

Figura 19- Gráfico 1: Diagnóstico de retinopatia diabética em função do tempo de diagnóstico de diabetes (em anos).

Figura 20- Gráfico 2: Diagnóstico de retinopatia diabética em função do tempo do tipo de diabetes (em frequência).

Figura 21- Gráfico 3: Diagnóstico de retinopatia diabética em função da taxa glicêmica $(\mathrm{mg} / \mathrm{dL})$.

Figura 22- Gráfico 4: Valores de limiar no CCT para cada um dos eixos de confusão de cores, para cada um dos grupos avaliados.

Figura 23- Gráfico 5: Valores de limiar no CCT em função da presença de retinopatia diabética. As linhas representam o desvio padrão da média.

Figura 24- Gráfico 6: Valores de limiar no CCT em função do tempo de diagnóstico de diabetes (em anos).

Figura 25- Gráfico 7: Valores de limiar no CCT em função do tipo de diabetes. As linhas representam o desvio padrão da média.

Figura 26- Gráfico 8: Valores de limiar no CCT em função da taxa glicêmica (em mg/dL).

Figura 27- Gráfico 9: Elipse de discriminação de cores para controles, em unidades u'v'.

Figura 28- Gráfico 10: Elipse de discriminação de cores para diabéticos, em unidades u'v'.

Figura 29- Gráfico 11: Valores de limiar para o eixo protan em função do haplótipo. As linhas representam o desvio padrão da média. 
Figura 30- Gráfico 12: Valores de limiar para o eixo deutan em função do haplótipo. As linhas representam o desvio padrão da média.

Figura 31- Gráfico 13: Valores de limiar para o eixo tritan em função do haplótipo. As linhas representam o desvio padrão da média.

Figura 32- Gráfico 14: Valores de limiar para o teste CCT em função do haplótipo e da presença de RD.

Figura 33- Gráfico 15: Valores de limiar para o teste CCT em função do haplótipo e do tipo de Diabetes Mellitus.

Figura 34- Gráfico 16: Média da taxa glicêmica (em mg/dL) para cada um dos haplótipos.

Figura 35- Gráfico 17: Valores de limiar para o teste CCT em função do haplótipo e dos antecedentes familiares de DM.

Figura 36- Gráfico 18: Elipse de discriminação de cores para pacientes diabéticos, com haplótipo TTA, em unidades u'v'.

Figura 37- Gráfico 19: Elipse de discriminação de cores para pacientes diabéticos, com haplótipo TTA/ GCC, em unidades u'v'.

Figura 38- Gráfico 20: Elipse de discriminação de cores para pacientes diabéticos, com haplótipo GCC, em unidades u'v'. 


\section{LISTA DE TABELAS-}

Tabela 1- Descrição dos primers utilizados e condições para a realização da PCR, para cada um dos polimorfismos pesquisados.

Tabela 2- Sequência de nucleotídeos utilizada para localização do SNP procurado e o alelo alvo.

Tabela 3- Características dos diabéticos participantes do estudo

Tabela 4- Características dos participantes controles do estudo (Idade, Gênero, Acuidade Visual e Antecedentes Familiares de DM).

Tabela 5- Média para os valores de Comprimento, semi-eixos, ângulo e área para Elipse de Discriminação de cores gerada para participantes controles.

Tabela 6- Média para os valores de Comprimento, semi-eixos, ângulo e área para Elipse de Discriminação de cores gerada para participantes controles. 


\section{LISTA DE ABREVIATURAS E SIGLAS-}

ADA: do inglês, American Diabetes Association;

AGE: do inglês, Advanced Glycation End-Products;

AV: Acuidade Visual;

AVcc: Acuidade Visual com correção;

AVE: Acidente Vascular Encefálico;

CCT: do inglês, Cambridge Colour Test;

DM: Diabetes Mellitus;

DNA: do inglês, desoxyribonucleic acid;

EPO: Eritropoietina;

ETDRS: Early Treatment Diabetic Retinopathy Study;

HAS: Hipertensão Arterial Sistêmica;

HCFMUSP: Hospital das Clínicas da Faculdade de Medicina da Universidade de São Paulo;

IPUSP: Instituto de Psicologia da Universidade de São Paulo;

ND: Nefropatia Diabética;

OD: Olho Direito;

OE: Olho Esquerdo;

OMS: Organização Mundial da Saúde;

PCR: do inglês, Polymerase Chain Reaction;

PEDF: do inglês, Pigment Epithelium-Derived Factor;

RD: Retinopatia Diabética;

RDNP: Retinopatia Diabética Não Proliferativa;

RDP: Retinopatia Diabética Proliferativa; 
SNP: do inglês, Single Nucleotide Polymorphisms;

TCLE: Termo de Consentimento Livre e Esclarecido;

UKPDS: do inglês, United Kingdom Prospective Diabetes Study;

VEGF: do inglês, Vascular Endotelial Growth Factor; 


\section{LISTA DE SÍMBOLOS-}

Kb: Quilo base;

mg/dL: Miligrama por decilitro;

mmol/L: Milimol por litro;

mL: Mililitro,

$\mu L:$ Microlitro;

nm: Nanometros;

pb: Pares de base;

$r s$ : do inglês, reference SNP; 


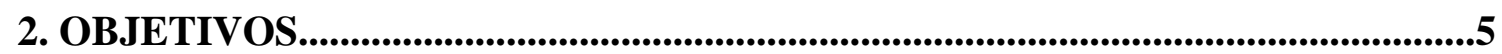

2.1. Objetivo Geral................................................................................................6

2.2. Objetivos Específicos..................................................................................................6

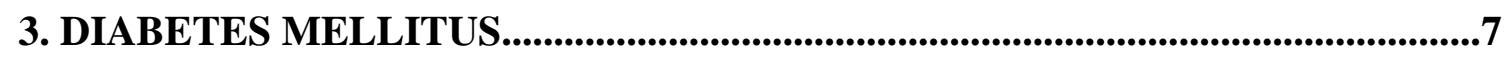

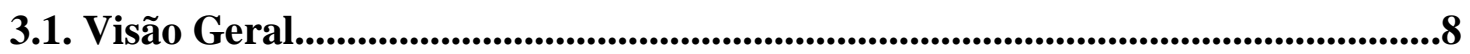

3.2. Complicações do DM.............................................................................................11

3.3. Alterações Vasculares no DM........................................................................................13

3.4. Alterações Visuais no DM..............................................................................................15

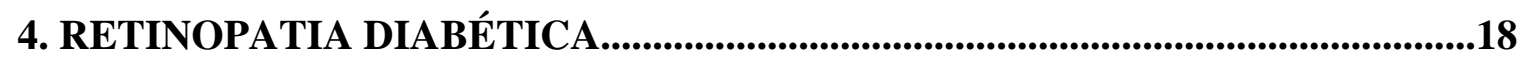

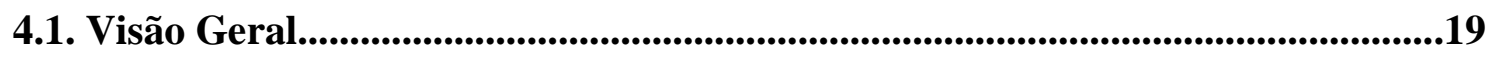

4.2. Fisiopatologia da RD..............................................................................................................24

4.3. O Papel da Eritropoietina no Desenvolvimento da DM.......................................31

4.4. SNPs para Expressão de EPO e sua Relação com DM...........................................36

5. VISÃO DE CORES.........................................................................................41

5.1. Visão Geral...............................................................................................................42

5.2. Espaço de Cores............................................................................................................46

5.3. Deficiências na Visão de Cores..........................................................................................49

6. MATERIAIS E MÉTODOS........................................................................................52

6.1. Aspectos Éticos....................................................................................................53

6.2. Participantes.........................................................................................................................53

6.2.1. Grupo Diabéticos..................................................................................................55

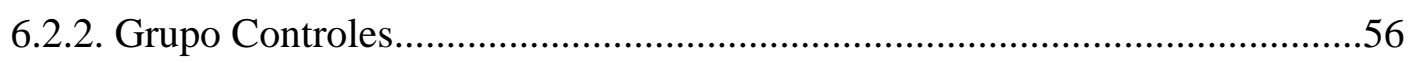




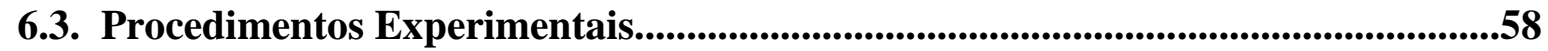

6.3.1. Anamnese e Avaliação Oftalmológica..........................................................58

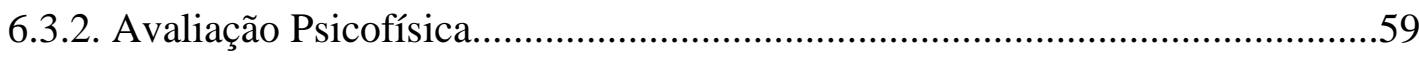

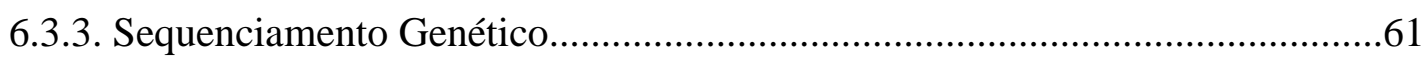

6.3.4. Análise Estatística....................................................................................66

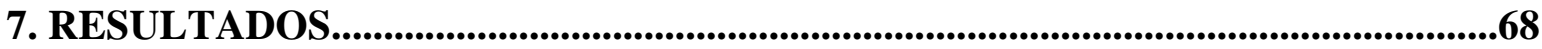

7.1. Participantes................................................................................................................................69

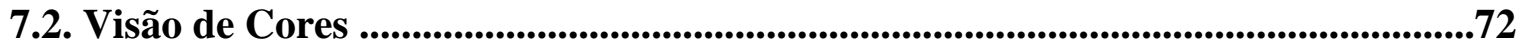

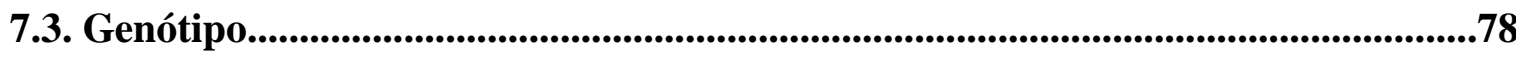

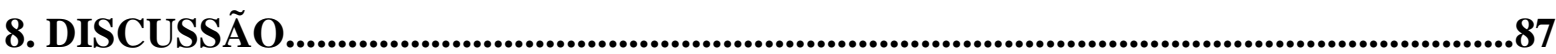

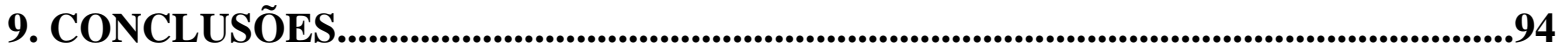

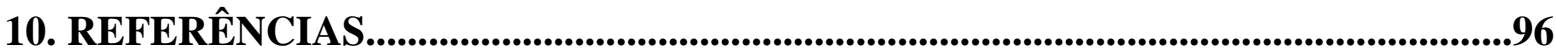

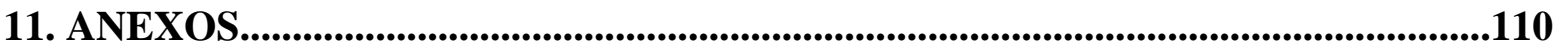


1. INTRODUÇÃO 
Este trabalho pretende dissertar sobre um aspecto de uma das complicações mais prevalentes no quadro de Diabetes Mellitus (DM): a Retinopatia Diabética. O aumento da expectativa de vida, aliado à manutenção de um estilo de vida pouco saudável, refletiu-se em um aumento na prevalência de diabetes e consequentemente, das comorbidades e complicações a ela ligadas.

O diagnóstico de DM está se tornando cada vez mais frequente. Estima-se que há cerca de 382 milhões de diabéticos, com perspectivas de atingir mais de 400 milhões em 2035 (SOCIEDADE BRASILEIRA DE DIABETES, 2015; ANTONETTI, KLEIN, GARDNER, 2012). Em 2000, o Brasil encontrava-se na lista dos 10 países com maior número de diabéticos, ocupando a oitava posição (WILD, ROGLIC, GREEN, SIGREE, KING, 2004). O mesmo estudo indicou uma estimativa na qual o Brasil passaria a ocupar a sexta posição do ranking em 2030, com o número absoluto de pacientes diabéticos passando de 4,6 milhões para 11,3 milhões.

Ao mesmo tempo, a RD é uma complicação bem prevalente do DM, sendo a principal causa de cegueira na faixa etária de 20 a 74 anos (SOCIEDADE BRASILEIRA DE DIABETES, 2015). A prevalência da RD apresenta números notáveis: mais de $90 \%$ entre diabéticos tipo 1 e $60 \%$ entre aqueles com o tipo 2 após 20 anos de doença, sendo que destes, 30\% apresenta a forma grave da doença (SOCIEDADE BRASILEIRA DE DIABETES, 2015). No entanto, ainda não há estudos nacionais com indicadores exatos, mas há estimativas baseadas em estudos internacionais que indicam aproximadamente 2 milhões de brasileiros com algum grau da doença (SOCIEDADE BRASILEIRA DE DIABETES, 2015). Por exemplo, em 2000, nos Estados Unidos, a prevalência da doença foi de 37\%, para pacientes acima de 40 anos (THE EYE DISEASES PREVALENCE RESEARCH GROUP, 2004; CIULLA, AMADOR, ZINMAN, 2003). O risco de cegueira pela patologia pode ser reduzido a menos de $5 \%$ se o diagnóstico for realizado precocemente e o tratamento correto iniciar-se em estágios mais incipientes da doença (SOCIEDADE BRASILEIRA DE DIABETES, 2015). No entanto, apenas a metade dos cinco milhões de diabéticos brasileiros que se submetem a tratamento endocrinológico recebe devida atenção oftalmológica (WHO, 2006).

Além das consequências visuais relativas à $\mathrm{RD}$, a presença da doença está associada a um aumento da mortalidade entre diabéticos, com um risco de desenvolvimento de outras alterações vasculares sistêmicas aumentado em duas vezes, em comparação com aqueles sem a patologia (ETDRS, 1999). Isto se deve ao fato da própria 
patologia ter um forte componente vascular. Dentre os principais fatores de crescimento vascular com possível atuação na RD, a Eritropoietina (EPO) vem ganhando destaque nas pesquisas mundiais, principalmente no que tange à relação entre sua expressão e o os alelos que a mediam na incidência do quadro de RD.

A EPO é tida como um importante fator de crescimento vascular, estimulando a proliferação, migração e angiogênese de células vasculares endoteliais expostas à hipóxia (ABHARY, BURDON, CASSON, GOGGIN, PETROVSKI \& CRAIG, 2010). Este hormônio tem sua expressão mediada por polimorfismos de único nucleotídeo ( $S N P$ Single Nucleotide Polymorphisms) em alelos localizados no Cromossomo 7q21.15 (TONG ET AL, 2008). Tong e colaboradores (2008) reportaram que para um destes SNPs (rs1617640), o alelo T está associado com maiores concentrações de EPO post-mortem em vítreo de humanos e camundongos diabéticos com complicações oculares e renais. O mesmo estudo aponta uma associação entre a expressão aumentada de EPO no vítreo e determinados SNPs, tidos assim como possíveis influências na suscetibilidade do desenvolvimento da RD (TONG et al, 2008; MOEMEN et al, 2013). Além do supracitado rs1617640, os que mostraram mais associação com o desenvolvimento de RD na literatura recente foram os SNPs rs507392 e rs551238. No entanto, tais estudos indicam diferentes alelos para o genótipo de risco. Uma possível causa para este achado é o fato de que a associação de um fenótipo com um único locus pode ser perturbada por efeitos de outros loci (MOEMEN et al, 2013). Da mesma forma, fatores ambientais podem influenciar a expressão de um determinado genótipo, bem como padrões diferentes de desequilíbrio de ligação (linkage disequilibrium) nas diferentes populações estudadas podem ser possíveis causas de tal discordância entre os estudos. Deste modo, pesquisas que pretendem estudar a associação entre os genótipos de risco e as alterações decorrentes do aumento de fatores de crescimento de neovasos podem contribuir para lançar luz sobre esta temática (LIN, VANCE, PERICAK-VANCE, MARTIN, 2007).

O debate sobre a participação de componentes neurais e de vasculares para a manifestação dos sintomas decorrentes do DM é intenso. As células ganglionares, por exemplo, degeneram-se antes que alterações vasculares possam estar presentes (KERN, 2014). Da mesma forma, a alta taxa metabólica exigida pelos fotorreceptores pode ser um fator contribuinte para o desenvolvimento de hipóxia (causando posterior neovascularização) na retina (KERN, 2014). Assim, trabalhos que pretendam lançar luz e discorrer acerca destas questões têm como pano de fundo um cenário ainda pouco 
compreendido. Desta forma, há diversos trabalhos que indicam que as alterações neurais na retina precedem as vasculares (BARBER, NAKAMURA, WOLPERT, REITER, SEIGEL, ANTONETTI, GARDNER, 2001; BARBER, 2003; ADAMS, BEARSE, 2012), enquanto outros indicam o oposto (CHEUNG, WONG, 2008; SHEETZ; KING, 2002).

Portanto, o presente trabalho almejou atrelar dados obtidos através do sequenciamento genético com aqueles adquiridos clinicamente, através de medidas psicofísicas relacionadas à visão de cores (e, portanto, indicativo de lesões de fundo neural). O intuito foi nutrir discussões que há muito aparecem na literatura especializada, especialmente em relação a duas questões: a) o papel de cada perfil genético no aumento da probabilidade de desenvolvimento de RD e b) o debate sobre a precedência de alterações neurais versus alterações vasculares no início do quadro da retinopatia diabética. 
2. OBJETIVOS 


\subsection{Objetivo Geral}

O objetivo do trabalho é investigar a associação entre o perfil genético para expressão de EPO e alterações funcionais na visão de cores de pessoas com diagnóstico de DM.

\subsection{Objetivos Específicos}

1) Averiguar a presença de danos na visão de cores em diabéticos, com e sem $\mathrm{RD}$, avaliados através de testes psicofísicos,

2) Verificar a frequência de haplótipo presente na região promotora do gene da $\mathrm{EPO}$, apontado como significativo na etiologia da RD, em amostra de diabéticos e de não diabéticos;

3) Investigar possíveis associações entre determinados polimorfismos e danos na visão de cores;

4) Contribuir para o esclarecimento sobre o papel do haplótipo formado pelos SNPs rs1617640, rs507392 e rs551238 como genótipo protetor ou de risco para o desenvolvimento de RD; 
3. DIABETES MELLITUS 


\subsection{Visão Geral}

Em termos gerais, o Diabetes Mellitus (DM) é um distúrbio metabólico crônico caracterizado por alta taxa glicêmica no sangue (hiperglicemia) devido a alterações em células pancreáticas. É decorrente de alterações na produção ou secreção de insulina pelo pâncreas ou pela diminuição da absorção sistêmica deste hormônio. Desde 1997, é classificada em tipo 1, tipo 2, diabetes gestacional e outros tipos específicos de DM, não sendo mais utilizada a classificação em insulinodependente e insulinoindependente (apesar desta denominação ainda ser encontrada em literatura não especializada) (DRAZNIM, EPSTEIN, TURNER, WASS, 2011).

Diabetes Mellitus Tipo 1: responde por 5 a $10 \%$ dos casos. Derivam da destruição das células $\beta$ das Ilhotas de Langherans do pâncreas, produtoras de insulina. De início abrupto, ocorre geralmente precocemente; no entanto, pode ocorre em pessoas das mais diversas idades. Na maioria dos casos, tal processo tem mediação autoimune, ocorrendo de forma mais veloz em crianças. Tal doença apresenta também intensa associação a genes do sistema antígeno leucocitário humano (HLA), que podem apresentar-se tanto como fator protetivo quanto de risco (ERLICH, VALDE, NOBLE ET AL, 2008; SOCIEDADE BRASILEIRA DE DIABETES, 2015).

Diabetes Mellitus Tipo 2: mais prevalente na população, respondendo por mais de 90\% dos casos. Pode ocorrer tanto pela baixa produção de insulina pelo pâncreas como secreção de um hormônio pouco funcional, sendo mais comum a concomitância entre os fatores. Assim como o tipo 1, pode ser diagnosticado em qualquer faixa etária, mas é mais comum após os 40 anos de idade. $\mathrm{O}$ aparecimento da doença está relacionado intimamente com fatores comportamentais como a obesidade, a má alimentação e o sedentarismo. Costuma apresentar uma sintomatologia mais leve que no tipo 1, não sendo necessário o uso de insulina exógena, exceto para melhor controle metabólico em casos mais difíceis. Quando sintomática, manifesta-se através de sintomas como poliúria, polidipsia, fadiga e perda abrupta de peso. Ainda não há achados genéticos conclusivos para esse distúrbio (SOCIEDADE BRASILEIRA DE DIABETES, 2015). No entanto, são conhecidos alguns fatores ambientais de risco, tais como obesidade, dieta pobre, sedentarismo, histórico familiar da doença e etnia.

Diabetes Gestacional: Acontece em 1 a 14\% das gestações, conforme população estudada (SOCIEDADE BRASILEIRA DE DIABETES, 2015). Caracteriza-se pelo 
diagnóstico de hiperglicemia durante o período gravídico, geralmente durante o segundo ou terceiro trimestre de gestação. A ação da insulina torna-se bloqueada, provavelmente pela ação de hormônios produzidos pela placenta. É relacionada com o aumento da mortalidade e morbidade perinatal e aumenta em $10 \%$ a $63 \%$ o risco de a parturiente vir a desenvolver DM tipo 2 dentro de 5 a 16 anos após o parto (SOCIEDADE BRASILEIRA DE DIABETES, 2015). Após o puerpério, a paciente é reavaliada, sendo que na maior parte dos casos, retorna-se à condição normoglicêmica.

Diabetes de Outros Tipos Específicos: São menos comuns e causadas por patologias e fatores bem delimitados e conhecidos. Estão inclusos nesta classificação condições como pancreatite, doenças do pâncreas exócrino, endocrinopatias, rubéola congênita, citomegalovírus, indução por substâncias ou drogas (muitas vezes, utilizadas no tratamento de HIV ou para controle de rejeição em transplante de órgãos) e defeitos na função das células $\beta$ de origem genética (gene MODY-Maturity-onset diabetes of the young).

Cabe ressaltar que nem sempre é possível estabelecer uma classificação clara do paciente em um dos tipos, já que os sintomas e a progressão da doença costumam variar. Muitas vezes, o tipo 2 permanece assintomático, em contrapartida do tipo 1, cujos sintomas ocorrem de maneira acentuada e abrupta. No entanto, é mais comum o desenvolvimento de cetoacidose diabética em pacientes com o tipo 2 .

O diagnóstico da doença é feito principalmente por meio de achados bioquímicos, baseados nos níveis glicêmicos em jejum e pós prandial. Segundo critérios utilizados pela Associação Americana de Diabetes (ADA) (DRAZNIM ET AL, 2011), os níveis glicêmicos plasmáticos normais em jejum encontram-se $<110 \mathrm{mg} / \mathrm{dL}$, sendo considerado diabetes após $126 \mathrm{mg} / \mathrm{dL}$ ( $7 \mathrm{mmol} / \mathrm{L}$ ). Quando os valores estão entre ambos, o quadro é denominado tolerância à glicose diminuída (glicemia em jejum alterada), critério ainda não reconhecido pela OMS (SOCIEDADE BRASILEIRA DE DIABETES, 2015). No entanto, é considerado fator de risco para o aparecimento posterior da hiperglicemia. O diagnóstico de diabetes também é considerado quando a glicemia casual (realizada em qualquer horário, mesmo pós prandial) atinge um valor maior que $200 \mathrm{mg} / \mathrm{dL}$, juntamente com sintomas de poliúria e polidipsia ou após duas horas de sobrecarga de glicose de $75 \mathrm{~g}$.

Em 2010, a ADA propôs a utilização da hemoglobina glicada (HbA1C) como critério diagnóstico, com a recomendação dos seguintes valores: entre 5,7 e 6,4\%: alto risco para diabetes; > 6,5\% (ponto de inflexão para a prevalência de RD): diabetes a ser 
confirmada através de outro exame. No entanto, a HbA1C não é tão utilizada quanto a glicemia plasmática para a realização de diagnóstico.

Com relação à prevalência da doença, há diferenças significativas entre os países e seus diversos grupos étnicos. Assim, há elevadas taxas de diabetes entre os Nauru e os Tokelau, na Oceania e entre os Pima, no Arizona (INTERNATIONAL DIABETES FEDERATION, 2013; SOCIEDADE BRASILEIRA DE DIABETES, 2015). Há também uma elevada taxa de diabéticos em países de baixa ou média renda, sendo que $80 \%$ dos acometidos pertencem a estes países (INTERNATIONAL DIABETES FEDERATION, 2013). De fato, o Pacífico Ocidental possui a maior prevalência mundial, com 138 milhões de pessoas afetadas (INTERNATIONAL DIABETES FEDERATION, 2013).

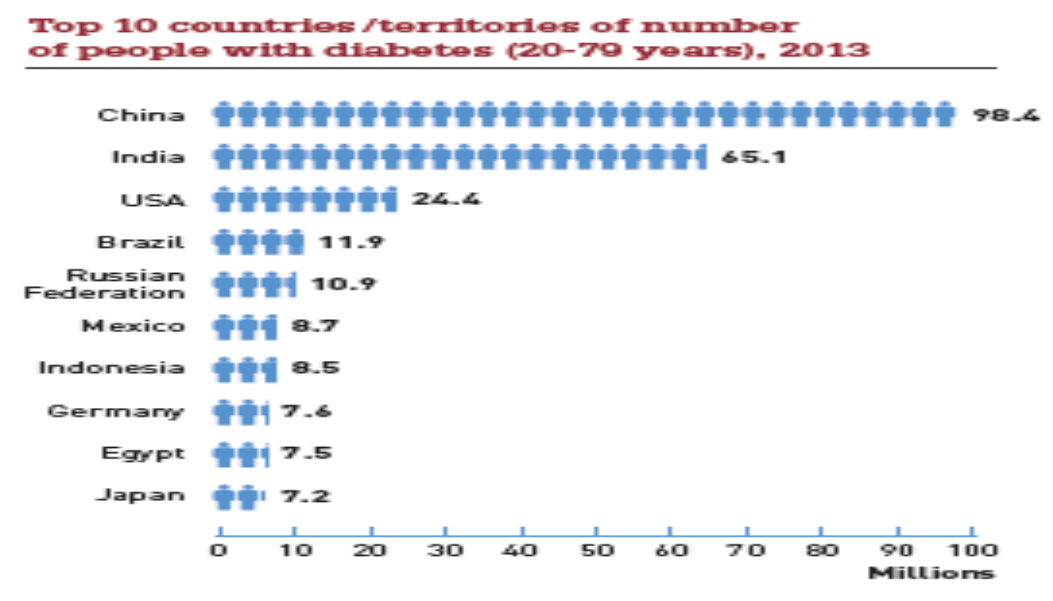

Figura 01- Prevalência da DM (em milhões de pessoas) nos dez países com o maior número de casos da doença, entre 20 e 79 anos de idade, em números absolutos. Extraído de: INTERNATIONAL DIABETES FEDERATION, 2013.

No Brasil, há uma grande prevalência entre os índios Xavantes $(28,2 \%$ da população); de fato, no Brasil, a prevalência do diabetes aumentou de 18,3\% em 1993 para 34,9\% em 2000 (SOCIEDADE BRASILEIRA DE DIABETES, 2015). As taxas de mortalidade por DM foram de 30,1 (por 100 mil habitantes) no ano de 2011, sendo que geralmente não se atribui à doença a causa principal da morte e sim, às complicações vasculares que acompanham o quadro (SOCIEDADE BRASILEIRA DE DIABETES, 2015). Ao se considerar as causas múltiplas do óbito, a taxa de mortalidade por DM aumenta até 6,4 vezes (SOCIEDADE BRASILEIRA DE DIABETES, 2015; FRANCO, 2004). 


\subsection{Complicações do Diabetes Mellitus}

Altas taxas glicêmicas estão relacionadas com alterações cardiovasculares, oculares, renais, no sistema nervoso e outras, além de aumentar significativamente a incidência de infecções nestes pacientes. Em decorrência disto, pacientes diabéticos necessitam de monitoramento constante para averiguar o desenvolvimento de alguma patologia nesses âmbitos. Devido a tais prevenções, a taxa destas complicações vem diminuindo nas últimas duas décadas no Brasil (SOCIEDADE BRASILEIRA DE DIABETES, 2014). As principais complicações relacionadas ao diabetes são relacionadas a seguir:

Doenças cardiovasculares: É a principal causa de morte e de morbidades entre diabéticos (INTERNATIONAL DIABETES FEDERATION, 2013). Inclui quadros de angina, infarto do miocárdio, insuficiência cardíaca congestiva, acidentes vasculares encefálicos e doença arterial periférica. Tais complicações no paciente diabético também estão relacionadas com hipertensão arterial sistêmica (HAS) e com dislipidemia. Portanto, diabéticos necessitam manter tais valores dentro de índices normais, para evitar as possíveis complicações. As medidas de profilaxia também envolvem a cessação obrigatória do tabagismo, aplicação de estatinas e uso contínuo de ácido acetilsalicílico (SOCIEDADE BRASILEIRA DE DIABETES, 2014).

Existem dois principais escores de risco de desenvolvimento de doenças vasculares no diabético: aquele desenvolvido pelo grupo de Framingham e do United Kingdom Prospective Diabetes Study (UKPDS) risk engine (SOCIEDADE BRASILEIRA DE DIABETES, 2014; D' AGOSTINO JR, VASAN, PENCINA, WOLF, COBAIN, MASSARO, 2008; STEVENS, KOTHARI, ADLER, STRATON, HOLMAN, 2001). Enquanto que o primeiro é um algoritmo de predição de eventos cardiovasculares em populações assintomáticas, como amplo uso para os diabéticos, o último utiliza dados sobre a própria DM (tais como duração do quadro e medida de HbA1c).

Doença renal (nefropatia): Consiste em danos vasculares nos rins, levando-os ao mau funcionamento ou até à falha completa (INTERNATIONAL DIABETES FEDERATION, 2013). Acomete cerca de 35\% dos pacientes, causando em muitos casos um aumento da excreção urinária de albumina (SOCIEDADE BRASILEIRA DE DIABETES, 2014). Aproximadamente $20 \%$ dos pacientes admitidos em programas para tratamento renal tem diabetes (INTERNATIONAL DIABETES FEDERATION, 2013). 
Inclusive, a taxa de excreção urinária de albumina é utilizada como critério diagnóstico para a diabetes, tendo como ponto de corte um valor maior que $300 \mathrm{mg} / \mathrm{dia}$.

A doença renal está associada ao aumento no risco de desenvolvimento de doenças cardiovasculares (SOCIEDADE BRASILEIRA DE DIABETES, 2014). Além disto, tal diagnóstico é considerado com mais frequência em pacientes com RD, já que alterações na vascularização da retina precedem as alterações renais (SOCIEDADE BRASILEIRA DE DIABETES, 2014). O tratamento para nefropatia envolve hemodiálise ou transplante renal; no entanto, algumas medidas e medicamentos podem retardar a progressão da doença, tais como um melhor controle glicêmico e lipídico.

Doença ocular (retinopatia diabética): Consiste na principal causa de cegueira em adultos. Está associada com a formação de microaneurismas no tecido retiniano, que podem desembocar em hemorragias vítreas ou pré-retinianas. A rede de vasos que suprem tal tecido torna-se então bloqueada e danificada, o que pode levar à cegueira. $\mathrm{O}$ risco de cegueira pode ser reduzido a menos de $5 \%$, desde que o diagnóstico ocorra em fases precoces do desenvolvimento da doença (SOCIEDADE BRASILEIRA DE DIABETES, 2014). O tratamento consiste na fotocoagulação a laser dos vasos danificados.

Os parâmetros para diagnóstico e tratamento de tal doença foram postulados por dois estudos: o Diabetic Retinopathy Study e o ETDRS (Early Treatment Diabetic Retinopathy), que determinou critérios mais modernos para RD não proliferativa. No entanto, a fim de evitar fragmentação na padronização da RD, foi proposta uma classificação baseada na gravidade da doença, no International Congress of Ophtalmology, em 2002, levando-se em consideração os critérios de ambos os estudos (SOCIEDADE BRASILEIRA DE DIABETES, 2014).

Doença neural (neuropatia): Alterações nos nervos periféricos podem ocorrer em decorrência da hiperglicemia combinada à hipertensão arterial sistêmica, podendo levar a problemas de digestão, de micção ou de ereção, entre outros (INTERNATIONAL DIABETES FEDERATION, 2013). Acometem mais comumente as extremidades corporais, especialmente os pés, podendo gerar alodínia e hiperalgesia, formigamento e perda de sensibilidade. Esta última é particularmente importante, já que o paciente pode deixar de notar ferimentos perigosos, tornando-se mais susceptível ao desenvolvimento de infecções.

A prevalência da neuropatia pode chegar a 50\%, está associada a um aumento de mortalidade na população acometida e muitas vezes envolvem casos de triopatia (incluindo 
retinopatia e nefropatia), aumentando assim a morbidade da doença (INTERNATIONAL DIABETES FEDERATION, 2013). O acometimento patológico da complicação surge de duas formas: polineuropatia sensorimotora simétrica e neuropatia autonômica. Está altamente associada com a taxa glicêmica no diabético; no entanto, outros mediadores patogênicos das complicações no DM, tais como o AGE (do inglês, Advanced Glycation End-Products) podem também estar envolvidos (DRAZNIM ET AL, 2011). O tratamento é realizado com medicamentos anticonvulsivantes, correção da hiperglicemia e intervenções dirigidas aos sintomas.

Outras Complicações: Outras complicações podem acometer diabéticos, entre elas: o pé diabético, problemas dentais e complicações gravídicas. No pé diabético, os danos neurológicos e vasculares podem predispor à infecções e úlceras, em muitos casos, ocasionando amputação. De fato, pessoas com diabetes podem apresentar um risco 25 vezes maior de amputação dos membros inferiores (INTERNATIONAL DIABETES FEDERATION, 2013). Em termos de saúde bucal, os diabéticos possuem um risco aumentado de desenvolver gengivite e perda dentária. Na gravidez, altas taxas glicêmicas podem aumentar o risco de desenvolvimento de anormalidades fetais, de sobrepeso fetal e de produção anormal de insulina (INTERNATIONAL DIABETES FEDERATION, 2013).

\subsection{Alterações Vasculares no DM}

Durante o quadro hiperglicêmico, diversas mudanças vasculares ocorrem e algumas teorias visam explicar tais alterações fisiopatológicas. Como os mecanismos metabólicos da glicemia são diversos, as alterações que acometem os pacientes diabéticos costumam acometer uma série de tecidos. Da mesma forma, encontram-se precocemente em pacientes diabéticos alterações hemodinâmicas, disfunções endoteliais, ativação de células inflamatórias e expressão de fatores de crescimento vascular e neurotróficos (SHEETZ, KING, 2002).

As teorias que visam explicar os danos podem ser subdivididas entre aquelas que enfatizam os efeitos tóxicos da hiperglicemia e de seus derivados patológicos, tais como produtos de glicação e oxidantes e as que ressaltam as alterações nos mecanismos de sinalização celular (SHEETZ, KING, 2002). Uma delas diz respeito às modificações irreversíveis em proteínas, causadas por glicídios no decorrer do envelhecimento, processo 
conhecido como Reação de Maillard. Tal reação é atribuída à formação dos denominados Produtos de Glicação Avançada (do inglês, Advanced Glycated End-Products-AGE). As alterações vasculares no DM ocorreriam, portanto, em uma espécie de envelhecimento celular precoce, por quebra nas ligações químicas e alterações estruturais causadas pela hiperglicemia (BARBOSA, OLIVEIRA, SEARA, 2008; SHEETZ, KING, 2002). Além disto, modificações em determinadas vias metabólicas podem afetar umas às outras, já que metabólitos glicosídicos participam concomitantemente em diversos mecanismos bioquímicos. Tal multiplicidade bioquímica é considerada crítica no desenvolvimento de novos fármacos e de uma terapêutica considerada efetiva (SHEETZ, KING, 2002).

Os AGEs estão presentes no tecido retiniano e acredita-se que possam exercer papel importante na permeabilidade das células endoteliais e aumentam a produção dos fatores de crescimento neovasculares (BARBOSA, OLIVEIRA, SEARA, 2008). Os pericistos possuem receptores para AGE e respondem a este metabólito aumentando a transdução sináptica, o que leva à saturação celular (BARBOSA, OLIVEIRA, SEARA, 2008).

Assim, as alterações vasculares presentes no DM não ocorrem meramente por estresse oxidativo, mas dependem de uma série de fatores moleculares. Além disto, as alterações vasculares no DM estão intimamente associadas; em pessoas com RD, o risco de desenvolvimento de doenças cardiovasculares aumenta significantemente (FULLER, STEVENS, WANG, 2001). Alguns trabalhos sugerem inclusive que a RD compartilha mecanismos genéticos com outras alterações vasculares (CHEUNG, WONG, 2008).

Em meados dos anos 40, fatores angiogênicos já eram contabilizados como fatores mediadores de crescimento vascular anormal do tecido retiniano no DM (MICHAELSON, 1948, APUD: AIELLO, 2005). Dentre eles, o fator de crescimento endotelial vascular (do inglês, Vascular Endothelial Growth Factor-VEGF) é tido como um dos principais mediadores de angiogênese intraocular e de permeabilidade endotelial na RDP, e é também relacionado ao edema macular diabético, à degeneração macular relacionada à idade, à oclusão vascular da retina e à retinopatia da prematuridade (MOHAN ET AL, 2012; AIELLO ET AL, 2005). No tecido retiniano saudável, há um equilíbrio entre fatores estimulantes e inibidores de angiogênese; em pacientes com DM, o uso de fatores inibidores de VEGF não está associado à regressão na formação de neovasos, o que sugere que outros fatores de formação de vasos possam estar em jogo na hiperglicemia (MOHAN ET AL, 2012; GARCIA-RAMIREZ \& HERNANDEZ, 2006). Estudos mostraram que 
níveis de VEGF no vítreo e no plasma de pacientes com RDP apresentam-se mais elevados que em controles (MOHAN ET AL, 2012; AIELLO ET AL, 1994, SENGER, GALLI, DVORAK, PERRUZZI, HARVEY \& DVORAK, 1983; KECK, HAUSER, KRIVI, SANZO, WARREN, FEDER \& CONNOLLY, 1989). No entanto, o mecanismo que promove tal aumento ainda permanece incerto; porém, sabe-se que a regulação dos níveis de VEGF ocorre por isquemia local, aumento de AGE e de outros fatores de crescimento, como o ILGF (do inglês, insulin-like growth factor) (MOHAN ET AL, 2012; PUNGLIA ET AL, 1997).

Dentre as principais causas de morbidade e mortalidade entre pessoas com DM estão as complicações cerebrovasculares. Como o tecido retiniano e cerebral possuem a mesma origem embriológica, alterações patológicas na RD podem ser preditivas de alterações microvasculares cerebrais (CHEUNG, WONG, 2008). Há, inclusive, evidências de que sinais de RD possam estar associados com acidentes vasculares encefálicos (AVE), independente dos fatores de riscos cerebrovasculares, mesmo em pessoas com DM subclínico (CHEUNG, WONG, 2008). Desta maneira, pacientes com RD ou com lesões encefálicas possuem duas vezes mais chances de sofrer um AVE; porém, ao apresentar ambos os quadros, o risco de acidente vascular aumenta em mais de 18 vezes (CHEUNG, WONG, 2008; WONG ET AL, 2002). Assim, apesar do mecanismo que relaciona alterações microvasculares nos tecidos retiniano e cerebral ainda não ser totalmente conhecido, há evidências de que tal associação ocorra.

\subsection{Alterações Visuais no DM}

A hiperglicemia acarreta diversas anormalidades biomoleculares, causando alterações funcionais no organismo, inclusive nos olhos e na retina. Foram encontradas maiores concentrações de sorbitol que o esperado em lentes de ratos diabéticos, o que pode estar relacionado à catarata precoce (GABBAY, 1973, APUD: TAYLOR \& AGIUS, 1988). A absorção de glicose pela retina é insulino-independente e o aumento glicêmico intracelular leva à ativação da enzima aldose redutase. A glicose é reduzida a sorbitol por essa enzima, o que pode explicar o aumento local de tal metabólito. No entanto, há um aumento discreto em comparação a outros metabólitos produzidos, o que torna a relação entre esse mecanismo e o surgimento de danos neurais ainda não totalmente desvendada (SHEETZ \& KING, 2002). 
Nos capilares normais, há uma relação de aproximadamente 1:1 entre pericistos e células endoteliais, sendo que os primeiros exercem controle na proliferação das segundas (DRAZNIN ET AL, 2012). Assim, eles exercem um papel importante no controle da proliferação vascular. Da mesma forma, o aumento da permeabilidade e o espessamento das membranas basais observados na hiperglicemia podem estar relacionados a danos nos capilares retinais, frequentemente observados no DM.

Alterações visuais presentes no DM variam conforme o tipo da doença (se tipo 1 ou 2), o tempo de instalação do quadro, o controle glicêmico, a presença de outras patologias sistêmicas, tais como HAS, gravidez e outros fatores (TSAI, DENNISTON, MURRAY, HUANG E ALDAD, 2011). Da mesma maneira, outras alterações oftalmológicas costumam cursar com RD, tais como olho seco, abrasividade da córnea, uveíte anterior, glaucoma neovascular, síndrome ocular isquêmica, papilite, rubeose, xantelasma, infecção orbital e paralisia de músculo extraocular-III e/ ou VI pares- (TSAI ET AL, 2011; SOUZA, RODRIGUES, 1997). Tais pacientes podem também apresentar catarata precoce, com um desenvolvimento mais avançado que em não diabéticos (TSAI ET AL, 2011). Além disto, 75\% dos pacientes com maculopatia possuem DM tipo 2 e, embora a chance de desenvolver essa doença seja 10 vezes maior no DM tipo 2 do que no tipo 1, 14\% dos DM 1 que perdem a visão foram atingidos por tal patologia (DRAZNIM ET AL, 2011). Trata-se de edema na área macular, que leva à distorção da visão central e à redução do campo visual, podendo cursar com exsudatos e alterações isquêmicas. A acuidade visual de pacientes com edema de mácula decai consideravelmente, assim como em casos de catarata precoce (DRAZMIN ET AL, 2011). Altas taxas glicêmicas podem ocasionar miopia, bem como hipoglicemia pode levar à hipermetropia (DRAZMIN ET AL, 2011).

Foram também reportadas perdas de sensibilidade ao contraste e a cores em pacientes com DM, iniciando-se com aproximadamente dois anos de diagnóstico da doença (AIZU, OYANAGI, HU E NAKAGAWA, 2002; BANGSTAD, BRINCHIMANNHANSEN, HULTGREN, DAHL-JORGENSEN \& HANSSEN, 1994; DEAN, ARDEN \& DORNHORST, 1997). Trabalhos utilizando modelos murinos mostraram alterações de origem neural na retina de camundongos diabéticos, tais como redução na espessura da camada interna da retina, no número de células ganglionares e de fibras nervosas, concomitante a um aumento de células gliais no nervo óptico e de expressão de proteína ácida fibrilar glial (GFAP, do inglês, glial fibrillary acidic protein) e apoptose neural na 
retina (AIZU ET AL, 2002; BARBER ET AL, 1998; SCOTT, ET AL, 1986; LIETH ET AL, 1998).

Deficiências adquiridas na visão de cores também têm sido relatadas nos casos de DM. Rockett e colaboradores encontraram déficits significativos no eixo azul-amarelo de confusão de cores, comparando diabéticos e indivíduos controles (ROCKETT, ANDERLE, BESMAN, 1987). Além disto, no subgrupo que havia sido submetido à fotocoagulação a laser, o déficit foi ainda maior. Da mesma maneira, Fong e associados (1999) relataram alterações na capacidade de discriminação de cores em $50 \%$ dos pacientes examinados, em uma amostra com 2700 participantes, proveniente do ETDRS. Hardy e colaboradores (1992) encontraram deficiências na discriminação cromática em diabéticos tipo 1 sem $\mathrm{RD}$, o que sugeriu que tal déficit estivesse mais relacionado à taxa glicêmica que 'às alterações vasculares. Gualtieri (2009) encontrou perda de discriminação difusa em pacientes diabéticos tipo 2 e Garcia (2012) referiu valores alterados em 20 diabéticos, em comparação com um grupo controle, especialmente no eixo de cores tritan. Outros trabalhos também indicam perda significativa no eixo tritan (FONG ET AL, 1999, KURTENBACK ET AL, 1999). Alguns autores consideram que tal perda específica ocorre em decorrência do amarelamento precoce da lente, que pode ter sido causado pelo elevado nível glicêmico, com consequente glicosilação proteica local. No entanto, Gualtieri (2004) encontrou que, proporcionalmente, as alterações no eixo de cores verde vermelho são maiores que as encontradas para o tritan, o que refuta a hipótese de escurecimento da lente. 
4. RETINOPATIA DIABÉTICA 


\subsection{Visão Geral}

A retinopatia diabética é a complicação mais comum do DM e a principal causa de cegueira na população adulta de países desenvolvidos (FIGUEIRA, 2010; DRAZNIM, ET AL, 2011: SOCIEDADE BRASILEIRA DE DIABETES, 2014). Nos Estados Unidos, em 2000, a prevalência de RD na população diabética acima de 40 anos de idade foi de 37\% (THE EYE DISEASES PREVALENCE RESEARCH GROUP, 2004; CIULLA, AMADOR, ZINMAN, 2003). No Brasil, não há estudos rigorosos que demonstrem a prevalência da $\mathrm{RD}$, mas alguns trabalhos referem uma variação entre 24 e 39\% (SOCIEDADE BRASILEIRA DE DIABETES, 2015). Já a prevalência global pode variar desde $10 \%$ na Noruega até $61 \%$ na África do Sul (INTERNATIONAL DIABETES FEDERATION, 2013). De fato, há uma disparidade entre a incidência de RD entre as diferentes etnias, com as maiores taxas ocorrendo em populações não caucasianas, indicando uma possível influência gênica no desenvolvimento da doença (DRAZNIM ET AL, 2011; INTERNATIONAL DIABETES FEDERATION, 2013).

A RD aumenta em 10 a 20 vezes a possibilidade de uma pessoa desenvolver cegueira (DRAZNIM ET AL, 2011). Nos diabéticos tipo 1, a RD costuma ter início 3,5 anos após a puberdade, enquanto que nos de tipo 2, algum grau da doença já é encontrado em 38\% dos pacientes à época do diagnóstico da DM (SOCIEDADE BRASILEIRA DE DIABETES, 2015). São apontados alguns fatores como predisponentes para RD, destacando-se a duração da doença e o nível glicêmico (SOCIEDADE BRASILEIRA DE DIABETES, 2015; INTERNATIONAL DIABETES FEDERATION, 2013). O aumento da pressão arterial também é tido como fator de risco para a piora da RD (SOCIEDADE BRASILEIRA DE DIABETES, 2015; INTERNATIONAL DIABETES FEDERATION, 2013).

Classifica-se a RD basicamente em dois tipos: retinopatia diabética não proliferativa (RDNP) e retinopatia diabética proliferativa (RDP). A classificação é baseada no exame de fundoscopia ou em imageamento da retina. O primeiro achado clínico é a formação de edema e de microaneurismas nos capilares da retina. Com o enfraquecimento dos vasos, exsudatos duros também passam a ser notados. Quando o dano vascular é importante o suficiente para que o fluxo sanguíneo seja alterado, áreas de infarto começam a surgir. Neste momento, notam-se através de angiografia por fluoresceína, áreas de pouca perfusão. Manchas algodonosas, que denotam infarto das fibras nervosas, também 
aparecem nesta fase. Conforme a doença avança, ocorre dilatação dos microvasos retinianos como resposta à isquemia. Na fase proliferativa da doença, há a formação e evolução de neovasos, bem como o surgimento de células gliais, que, tracionados pelo humor vítreo, podem gerar sangramentos, fibrose e descolamento de retina. Este estágio é subdivido em inicial, de alto risco e avançado, segundo o grau de comprometimento. Em alguns casos, a proliferação de novos vasos também atinge a porção anterior dos olhos e a obstrução do fluxo dos fluídos oculares pode gerar glaucoma neovascular. Além do edema macular, se houver danos extensos de capilares na região foveal, a acuidade visual pode diminuir significativamente, devido ao suprimento sanguíneo inadequado à região. A figura 2 mostra o espessamento da fóvea de um paciente com RDP, com surgimento de cistos e de acúmulo de fluído local.

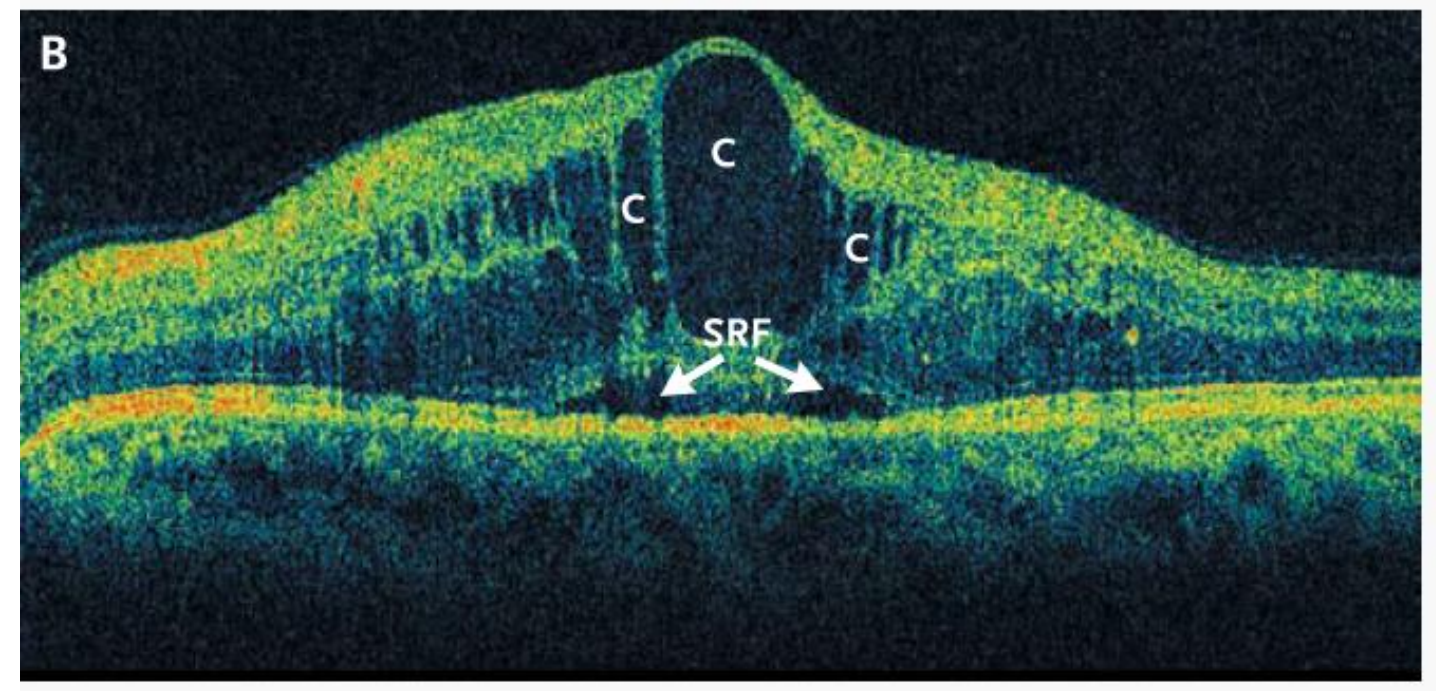

Figura 2- Tomografia de Coerência Óptica (OCT) de OD de paciente do sexo masculino de 57 anos de idade, com RDP e edema macular. A fóvea revela espessamento marcado e presença de cistos (indicados por C) e fluído sub-retinal (indicado em SRF). Extraído de Antonetti, 2012.

Dentre as comorbidades mais comuns, encontra-se o edema macular, caracterizado pela presença de espessamento do tecido retiniano, em conjunto com exsudatos duros no polo posterior. É classificado em leve, moderado ou grave, conforme a aproximação com o centro da fóvea. Quanto mais próximo do centro da fóvea, maior a gravidade. Tal quadro causa distorções na visão central, diminuindo a acuidade visual. Exsudatos podem levar a hemorragias. Além disto, isquemia de capilares pode estar presentes; no entanto, nestes casos, a mácula pode apresentar-se clinicamente normal, com danos apenas visíveis através de angiografia. Sugere-se que cerca de 95 mil americanos por ano irão desenvolver edema de mácula (DRAZMIN ET AL, 2012). Apesar de o edema 
macular poder surgir em qualquer fase de desenvolvimento da $\mathrm{RD}$, é mais comum o aparecimento em estágios mais avançados da doença, quando já há danos vasculares e neurais (ANTONETTI ET AL, 2012; STITT, CURTIS, CHEN, MEDINA, MCKAY, JENKINS, GARDINER, LYONS, HAMMES, SIMO, LOIS, 2015). O Quadro 1 traz as principais características e achados clínicos para cada uma destas subdivisões:

Quadro 1. Principais características e achados clínicos para cada fase da RD.

\begin{tabular}{|c|c|}
\hline $\begin{array}{l}\text { Gravidade da } \\
\text { doença }\end{array}$ & Características \\
\hline RDNP leve & Presença de microaneurismas, microhemorragias e exsudatos duros \\
\hline RDNP moderada & $\begin{array}{l}\text { Achados vasculares em maior quantidade que na RDNP leve, porém } \\
\text { menos abundantes que na forma grave da doença, presença de } \\
\text { exsudatos moles }\end{array}$ \\
\hline RDNP grave & $\begin{array}{l}\text { Presença de um ou mais dos seguintes achados: mais de } 20 \\
\text { hemorragias em cada um dos quatro quadrantes, formação de bolsas } \\
\text { venosas em dois quadrantes, anormalidades microvasculares } \\
\text { intrarretinianas em pelo menos um dos quadrantes, }\end{array}$ \\
\hline RDP & $\begin{array}{l}\text { Presença de pelo menos um dos seguintes achados: neovascularização } \\
\text { e/ou hemorragia vítrea/pré-retinal. }\end{array}$ \\
\hline
\end{tabular}

Para cada um dos achados presentes na RDNP grave (hemorragias, bolsas venosas e anormalidades microvasculares), há um aumento no risco de perda total da visão; assim, se uma das características estiver presente, o risco de cegueira é de aproximadamente 15\%, mas se houver duas, a chance é de $45 \%$ (DRAZMIN ET AL, 2012). No entanto, mesmo as formas graves da doença podem ser acompanhadas de sintomas leves, o que justifica a recomendação de exames oftalmológicos anuais para pacientes diabéticos. A Figura 3 mostra uma fotografia de fundo de olho em um caso de RDP. Nota-se a presença de exsudatos, de formação de neovasos e de hemorragias em todo o tecido retiniano. 


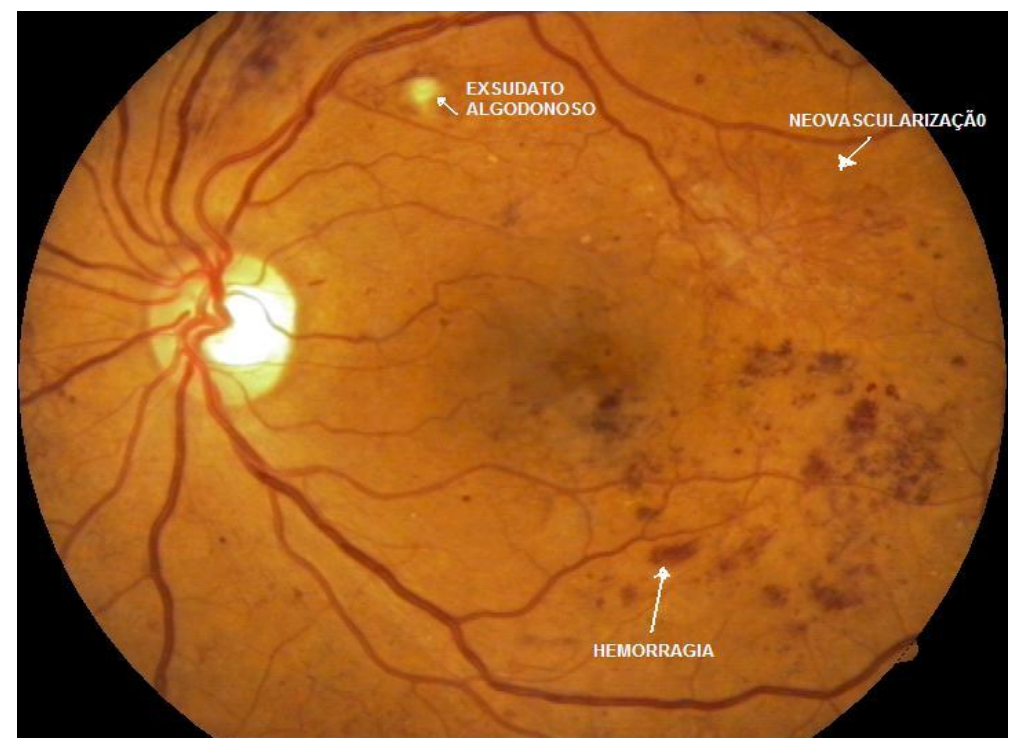

Figura 3- Imagem ilustrando um fundo de olho em um quadro de RDP. Observa-se o nervo óptico à esquerda na imagem (região mais iluminada), bem como a fóvea à direita (região mais escura). Extraído de: www.institutoderetina.com.br

A RD foi descrita primeiramente no século XIX, sendo que era tratada anteriormente por meio da ablação da pituitária. No entanto, devido às graves consequências do hipopituarismo, morte inclusive, a fotocoagulação panretinal começou a ser utilizada. O tratamento de escolha na fase proliferativa da RD é a fotocoagulação a laser, que não previne a formação de neovasos, mas mitiga as alterações presentes no tecido, necessitando ser empreendida diversas vezes no decorrer do curso da doença. $\mathrm{O}$ manejo dado e as normas concebidas para a prevenção e tratamento da RD têm diminuído o risco a incidência e a progressão da doença de $90 \%$ para 50\% (ANTONETTI ET AL, 2012). Além disto, a melhora na expectativa da incidência de problemas vasculares relacionados ao DM deveu-se ao surgimento de aparelhos de automonitoramento da glicose plasmática, da administração de insulina, bem como ao desenvolvimento de medicamentos hipoglicemiantes e de novos procedimentos cirúrgicos (ex: vitreoctomia) (ANTONETTI ET AL, 2012; DIABETES CONTROL AND COMPLICATIONS TRIAL, 1993). No entanto, ainda há um aumento da ocorrência de episódios hipoglicêmicos e de obesidade em pacientes com DM, chegando ao dobro de casos de sobrepeso que há 30 anos (ANTONETTI ET AL, 2012). 
O tratamento da RD envolve, portanto, medidas comportamentais e de mudança de estilo de vida, assim como intervenções cirúrgicas. Desta maneira, os pacientes são orientados a monitorar o nível glicêmico, mantendo-o sob controle. Pacientes monitorados pelo UKPDS durante nove anos e com bom controle glicêmico mostraram uma melhora de $21 \%$ na progressão da RD e uma redução de $29 \%$ na necessidade de fotocoagulação (DRAZMIN ET AL, 2011). Outros fatores também aumentam o risco de cegueira no caso de RD. Em estudo realizado nos Estados Unidos (Diabetes Control and Complications Trial-DCCT), comparou-se pacientes tipo 1 submetidos à terapia insulínica intensiva com aqueles em insulinoterapia convencional. Observou-se redução de $54 \%$ no risco de progressão da RD; entre aqueles que não apresentavam retinopatia, houve redução de $76 \%$ no risco de desenvolvimento (DIABETES CONTROL AND COMPLICATIONS TRIAL, 1993). Da mesma forma, a redução em $1 \%$ do nível de hemoglobina glicada leva a uma diminuição em 35\% do risco de desenvolvimento de RD e em 39\% de progressão entre aqueles já com a doença (DIABETES CONTROL AND COMPLICATIONS TRIAL, 1996).

A pressão sistêmica e os níveis lipídicos também são associados com um melhor prognóstico da RD. Foram observadas melhoras em achados clínicos relacionados à RD em pacientes DM tipo 1 em uso de Enalapril® e de Lisinopril ${ }^{\circledR}$ (medicamentos utilizados para controle da HAS) (DRAZMIN ET AL, 2011; CHEUNG \& WONG, 2008). Estudos apontam que uma redução de $10 \mathrm{mmHg}$ na pressão sistólica diminui em $13 \%$ o risco de evolução de complicações microvasculares no DM (UKTDS,1998). O mesmo estudo acompanhou pacientes durante nove anos e o controle a pressão arterial diminuiu a progressão do quadro de RD em $47 \%$.

Com relação à hiperlipidemia, há evidências que sugerem que o "colesterol ruim" (LDL-do inglês, low-density lipoprotein), após sofrer oxidação, possui um efeito citotóxico para as células endoteliais. Uma taxa de colesterol total maior que $270 \mathrm{mg} / \mathrm{dL}$ está relacionada a uma chance quatro vezes maior de desenvolvimento de RDP em comparação com pacientes que apresentem taxa de $200 \mathrm{mg} / \mathrm{dL}$ (DRAZMIN ET AL, 2011). Além disto, também são retratados piores resultados para a fotocoagulação em pacientes que possuem hipercolesteromia (DRAZMIN ET AL, 2011). Apesar dos resultados de pesquisa ainda não serem consistentes, algumas medidas vêm sendo indicadas como efetivas na diminuição da progressão da doença. Entre elas, a cessação do tabagismo e do consumo de álcool, o uso de agentes antiplaquetários e de inibidores de 
proteína kinase-C e de fatores de crescimento vascular (anti-VEGF) estão sendo ainda investigados (DRAZMIN ET AL, 2011).

Dentre as medidas cirúrgicas, a fotocoagulação a laser é uma das mais utilizadas. São realizadas, mediante anestesia local, pequenas cauterizações de 100 a $500 \mu \mathrm{m}$ de diâmetro na retina. A energia do laser é absorvida pela coroide e pelo epitélio pigmentar, atingindo a camada neurosensorial, que é assim também destruída, juntamente com os capilares. A figura 4, abaixo, mostra uma fotografia de fundo de olho imediatamente após fotocoagulação a laser. O principal objetivo da cirurgia é prevenir perdas visuais mais severas, especialmente, quando há maculopatia, reduzindo-as em até 80\% (DRAZMIN ET AL, 2011). No entanto, além de não conseguir restaurar perdas já sofridas, a cirurgia envolve riscos, como cauterização acidental da fóvea, redução da visão noturna e em alguns casos, a diminuição do campo visual, o que altera a capacidade do indivíduo em dirigir. Se há sinais de fibrose, de hemorragia intravítrea ou de opacidade severa, uma vitreoctomia pode ser indicada, antes do tratamento com laser. Tal procedimento também é indicado quando há riscos consideráveis de tração do tecido da retina. Com relação aos procedimentos cirúrgicos, cerca de $15 \%$ de pacientes que são submetidos à cirurgia de catarata são diabéticos (DRAZMIN ET AL, 2011).

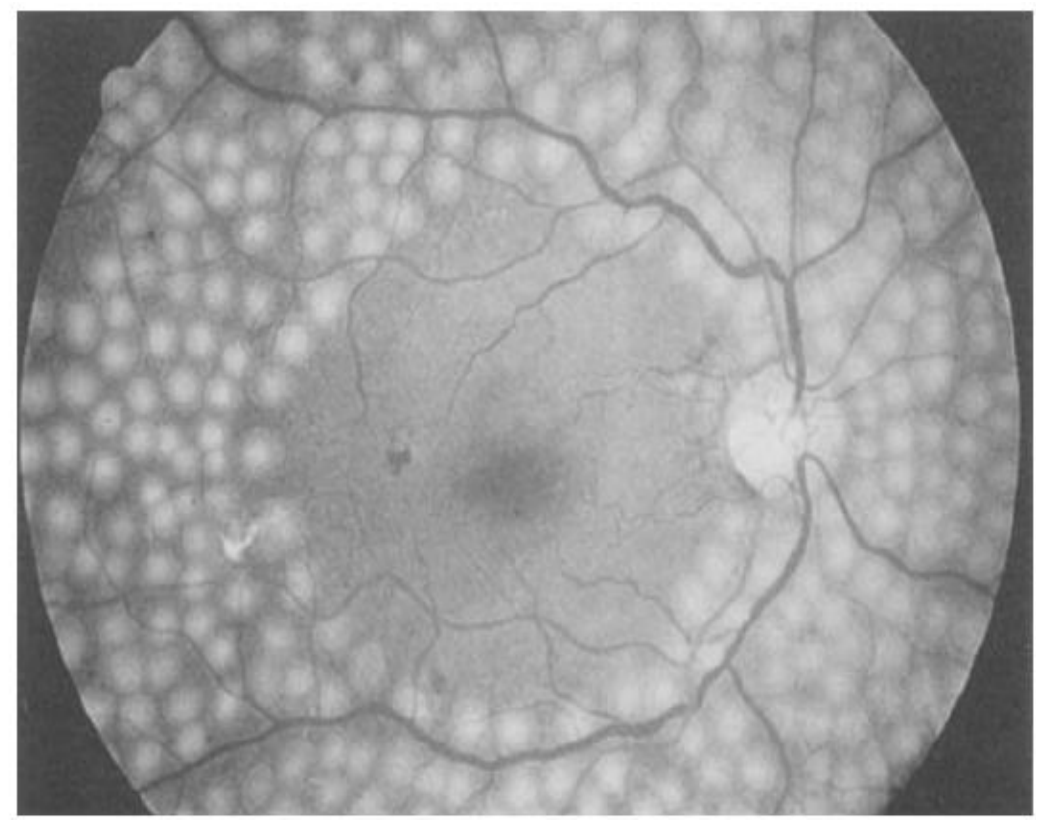

Figura 4- Imagem ilustrando um fundo de olho imediatamente após a realização de fotocoagulação a laser. Os pontos mostram os locais de cauterização e estão presentes logo após a cirurgia, desaparecendo em poucas horas. 


\subsection{Fisiopatologia da Retinopatia Diabética}

A diminuição do número de pericistos é a alteração mais precocemente observada no quadro de RD e esta perda também é tida como um dos fatores que altera a permeabilidade da barreira hematorretiniana (CUNHA-VAZ, 2007). A remoção do gene para expressão do fator $\beta$ de crescimento derivado de plaquetas (do inglês, platelet-derived growth factor - PDGF) leva à perda do pericistos e a manifestações muito semelhantes às observadas na RD (PKC-DRS 2 GROUP, 2006; ANTONETTI ET AL, 2012).

Outra modificação observada é a proliferação endotelial nos capilares e vênulas, acompanhada de edema e degeneração de ramificações vasculares de menor calibre (CUNHA-VAZ, 2007). Todas estas transformações resultam em mudanças na barreira hematorretiniana, gerando acúmulo de líquido intrarretiniano, edema macular e formação de exsudatos duros. No tecido retiniano, a absorção da glicose é mediada pelos transportadores GLUT1. Ou seja, além de ser uma doença de aspecto vascular, há também um componente fisiológico importante, já que diversas alterações neste campo podem ser observadas antes do surgimento da RD. São apontadas entre elas: apoptose de células ganglionares, de células de Muller e amácrinas, aumento de reatividade das células gliais e da microglia, alteração do metabolismo do glutamato e da expressão proteica ativada em mecanismos compensatórios durante o estresse metabólico (FLETCHER, PHIPPS, WARD, PUTHUSSERY, WILKINSON-BERKA，2007; HAMMES, FEDEROFF \& BROWNLEE, 1995; GASTINGER, SINGH \& BARBER, 2006; WANG, WU, JIANG, WANG, WANG, CHAO \& TONG, 2007).

O edema macular é a alteração clínica mais frequentemente relacionada à perda de visão na DM e caracteriza-se pelo espessamento da área foveal central. $\mathrm{O}$ tratamento desta complicação com fatores anti-VEGF (Aflibercept®, Ranibizumab® e Bevacizumab®) mostrou-se promissor (ANTONETTI ET AL, 2012). Além disto, o VEGF altera as proteínas de junções (tight-junctions) nas células vasculares endoteliais na retina, além de aumentar a permeabilidade vascular (MOHAN ET AL, 2012). No entanto, apesar da inibição de VEGF reduzir a neovascularização no tecido retiniano, não é capaz de inibir a formação de neovasos em casos de isquemia, o que aponta que talvez haja outros fatores envolvidos na relação VEGF e neovascularização (AIELLO ET AL, 1995; ANTONETTI ET AL, 1999). Além disto, foi indicada uma relação entre a diminuição do Fator derivado do Epitélio Pigmentar (do inglês, Pigment epithelium-derived factor, PEDF) e o aumento 
da expressão de VEGF. A produção de PEDF, tido como um conhecido fator de angiogênese, é diminuída em casos de hipóxia; além disto, altas taxas glicêmicas também podem diminuir a expressão de PEDF no tecido retiniano (DAWSON ET AL, 1999). Em estudo envolvendo a medição dos níveis de VEGF, de EPO e de PEDF no vítreo e no plasma de pacientes com RDP, Mohan e colaboradores (2012) encontraram níveis elevados dos dois primeiros fatores, bem como uma diminuição do terceiro. Além disto, os autores do estudo também encontraram que a expressão de EPO e de VEGF também apresentaram índices mais elevados em pacientes diabéticos sem complicações que nos controles. Da mesma forma, a expressão de PEDF foi menor nos diabéticos sem retinopatia que nos sujeitos controles. Além da RD, o VEGF é tido como mediador em casos de edema macular, de degeneração macular relacionada à idade, de oclusão vascular na retina e de retinopatia da prematuridade (AIELLO ET AL, 1994; AIELLO, 2005).

Fatores Finais de Glicação Avançada (AGE) acumulam-se sob condições hipoglicêmicas, agindo na indução de ligações cruzadas em proteínas de longa vida, promovendo assim rigidez muscular, alterando estruturas e funções vasculares, além de induzir estresse oxidativo e aumento de resposta inflamatória (SHARMA ET AL, 2012). Receptores para AGE (RAGE) estão espalhados por diversas células presentes no tecido retiniano, e quando ligados ao AGE, levam à ativação de vias de sinalização próinflamatórias e pró-oxidantes; da mesma maneira, tais receptores podem estar diretamente relacionados à neurodegeneração, às respostas inflamatórias e à disfunção microvascular na retina de pacientes com RD (ZONG, WARD, STITT, 2011). A acumulação de tais fatores de glicação no subendotélio levam a migração dos monócitos através da camada endotelial, o que ativa o fator nuclear NF-kB, também ligado a funções inflamatórias (WAN ET AL, 2015).

Já Liu e colaboradores (2010) coletaram lágrimas de diabéticos com e sem diagnóstico de RD e comparam-nas com pacientes controles. As lágrimas de diabéticos apresentaram níveis elevados de citocinas pró angiogênicas que anti angiogênicas, comparados aos controles. Além disto, tais mudanças bioquímicas foram observadas tanto em diabéticos com RD quanto naqueles sem RD; ou seja, as condições encontradas estiveram relacionadas ao diagnóstico de DM e mesmo sem apresentar complicações oculares, a resposta inflamatória já estava alta. Os autores do supracitado trabalho sugerem que reações inflamatórias crônicas podem ocorrer na superfície ocular de diabéticos e que, 
portanto, intervenções baseadas na supressão de certas citocinas podem auxiliar na prevenção de complicações na DM.

No DM, há também um aumento de leucostase ocular, afetando a função endotelial no tecido retiniano e levando a não perfusão capilar, danos às células e enfraquecimento dos microvasos na retina (MIYAMOTO \& OGURA, 1999; CIULLA, AMADOR, ZINMAN, 2003). Os leucócitos são células que possuem alta rigidez citoplasmática e, com o quadro de DM, tendem a se tornar menos elásticas; além disto, tais células produzem radicais tóxicos e enzimas proteolíticas (MIYAMOTO \& OGURA, 1999; CIULLA, AMADOR, ZINMAN, 2003). Há muitos capilares que sofrem oclusão pelos leucócitos, que apresentam grande tamanho e angiografia por fluoresceína pode mostrar que há leucócitos presos em área de perfusão e com diminuição da microcirculação (MIYAMOTO \& OGURA, 1999). No entanto, não apenas leucócitos, mas também células sanguíneas como um todo parecem exercer um papel importante em tais alterações.

Espécies reativas ao oxigênio (do inglês, Reactive Oxygen Species- ROS) encontram-se aumentadas em quadros de hiperglicemia, resultando em metabolismo anormal, que por sua vez, também podem produzir ROS; além disto, o tecido da retina é rico em ácidos graxos, com alto consumo de glicose e de oxigênio, deixando-o mais vulnerável ao estresse oxidativo (KOWLURU \& MISHRA, 2015). Um sistema eficiente para antioxidação deve estar ativo para desintoxicar tais produtos; no entanto, em quadros onde ocorre um desbalanço entre a quantidade de ROS produzida e a destruída, pode haver danos significativos nos tecidos. A exposição anormal a tais espécies pode levar a danos ao DNA mitocondrial e levar a danos no transporte de elétron (KOWLURU \& MISHRA, 2015).

A hiperglicemia também pode ativar da Proteína kinase C (PKC), que está ligada com um aumento da permeabilidade vascular, alterações no fluxo sanguíneo, na estimulação da formação de neovasos, na aceleração de apoptose nas células capilares (KOWLURU \& MISHRA, 2015; GERALDES ET AL, 2009). A ativação de PKC também estimula a formação de diacilglicerol (DAG), além de inibir a expressão de sintase do óxido nítrico nas células endoteliais (WAN ET AL, 2015). Tais fatores levam a um aumento do estresse oxidativo, desembocando em um aumento de produção de ROS. A Figura 5, abaixo, mostra um esquema representando uma retina normal e uma com RDP. Desta forma, é possível notar o aumento de VEGF e de receptores para tal, bem como o aumento de ROS, desembocando na formação de neovasos. 


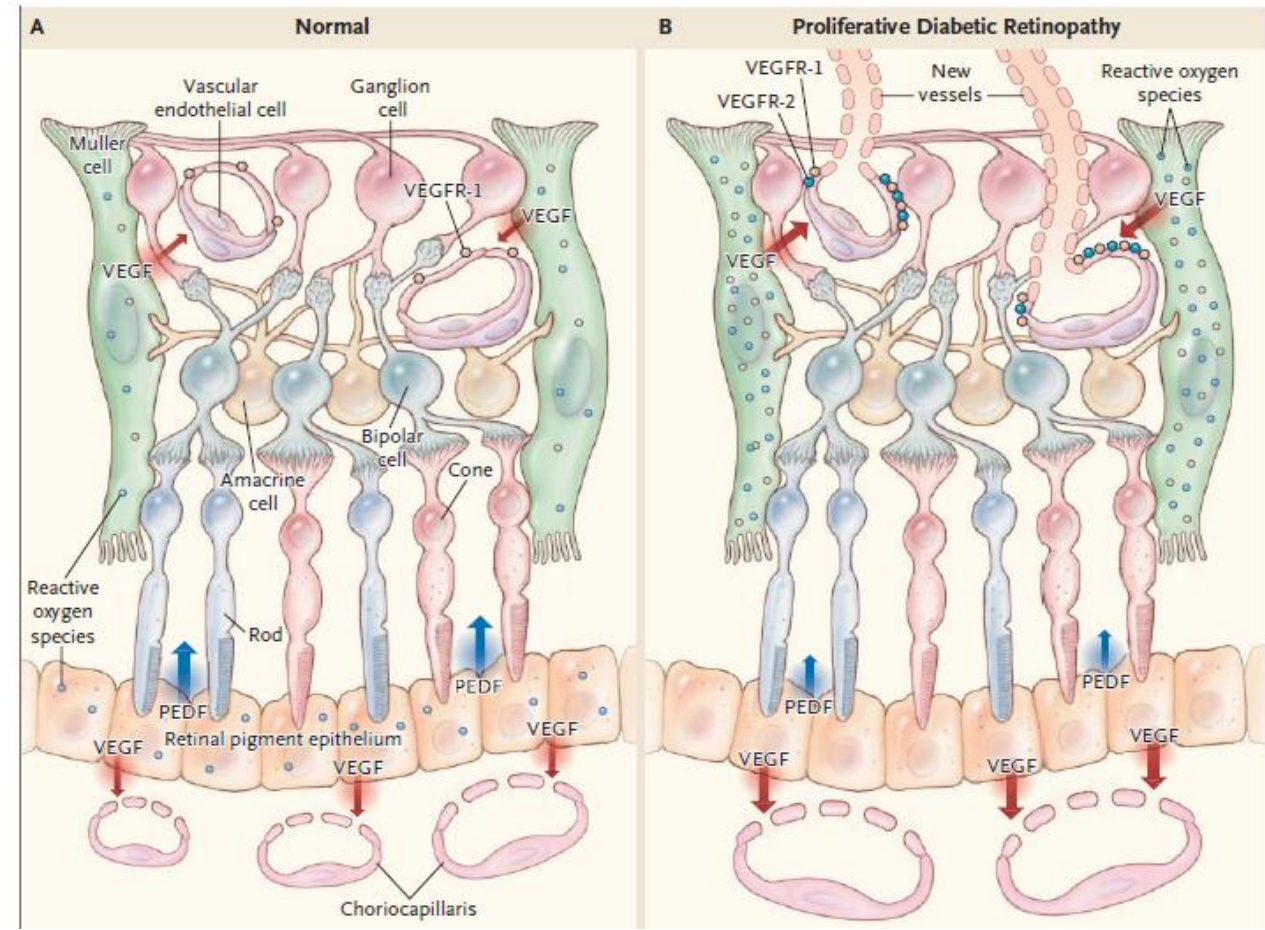

Figura 5- Esquema anatômico de uma retina normal e com RDP. Nota-se o aumento de VEGF, de ROS (Reactive Oxygen Species), bem como a formação de neovasos. Extraído de: FRANK, 2004.

Atualmente, o debate acerca das causas neurais versus vasculares para os prejuízos visuais decorrentes do DM é intenso (KERN, 2014). Alguns trabalhos mostram que alterações neurais na retina precedem as vasculares (BARBER, NAKAMURA, WOLPERT, REITER，SEIGEL，ANTONETTI，GARDNER，2001；BARBER，2003; ADAMS, BEARSE, 2012) No entanto, há outros trabalhos que apontam o oposto (CHEUNG, WONG, 2008; SHEETZ; KING, 2002). Apesar de ser uma doença essencialmente vascular, processos neurodegenerativos já se apresentam na retina antes de quaisquer anormalidades microvasculares surgirem e são apontados inclusive como participantes ativos nos processos de neovascularização (BARBER, 2003; VILLAROEL ET AL, 2010). Níveis elevados de glutamato e uma expressão aumentada no sistema renina-angiotensina possuem um papel fundamental no processo de neurodegeneração que ocorre na retina nos casos de RD (VILLAROEL ET AL, 2010). Tanto apoptose neural quanto ativação glial ocorrem na retina antes que alterações vasculares possam ser vistas; as células ganglionares são as tidas como as primeiras e as que mais sofrem apoptose (VILLAROEL ET AL, 2010). Danos neurorretinais levam a anormalidades funcionais, tais como perda de discriminação 
cromática, sensibilidade ao contraste e de adaptação ao escuro (VILLAROEL ET AL, 2010). Além disto, ligados à perda de discriminação cromática, os fotorreceptores são associados com danos vasculares na RD; são células que possuem um uma alta taxa metabólica, especialmente no escuro, quando os bastonetes atingem o máximo de seu metabolismo (KERN \& BERKOWITZ, 2015). As maiores taxas de aumento de estresse oxidativo parecem ser encontradas nos fotorreceptores, pois eles contêm o maior número de mitocôndrias no tecido retiniano e tal organela produz alta concentração de oxigênio reativo (KERN \& BERKOWITZ, 2015).

Aizu e colegas (2002) pesquisaram ratos diabéticos por indução com streptozotocina (STZ) foram investigados por microscopia e por eletrorretinografia. Após um mês de início da DM, tanto a camada plexiforme interna quanto os fotorreceptores já se encontravam diminuídos. Da mesma forma, a equipe encontrou invaginações nas camadas basais do epitélio pigmentar dos ratos após um mês de indução da doença e grandes concavidades no citoplasma das células da mesma camada após seis meses de DM. Os autores ainda relevam que com relação ao eletrorretinograma, foram registradas reduções nas amplitudes das ondas $\alpha$ e $\beta$ e no potencial oscilatório após um mês de doença. Considerando que ondas $\alpha$ são provenientes principalmente dos fotorreceptores e que as ondas $\beta$ refletem as atividades principalmente das células bipolares, pode-se sugerir que disfunções na neurorretina já se encontram presentes mesmo em estágios iniciais da doença. A figura 6 mostra as retinas dos ratos do estudo supracitado, após um e seis meses de doença, comparados com controles; nota-se a diminuição de fotorreceptores, em comparação com os controles. 

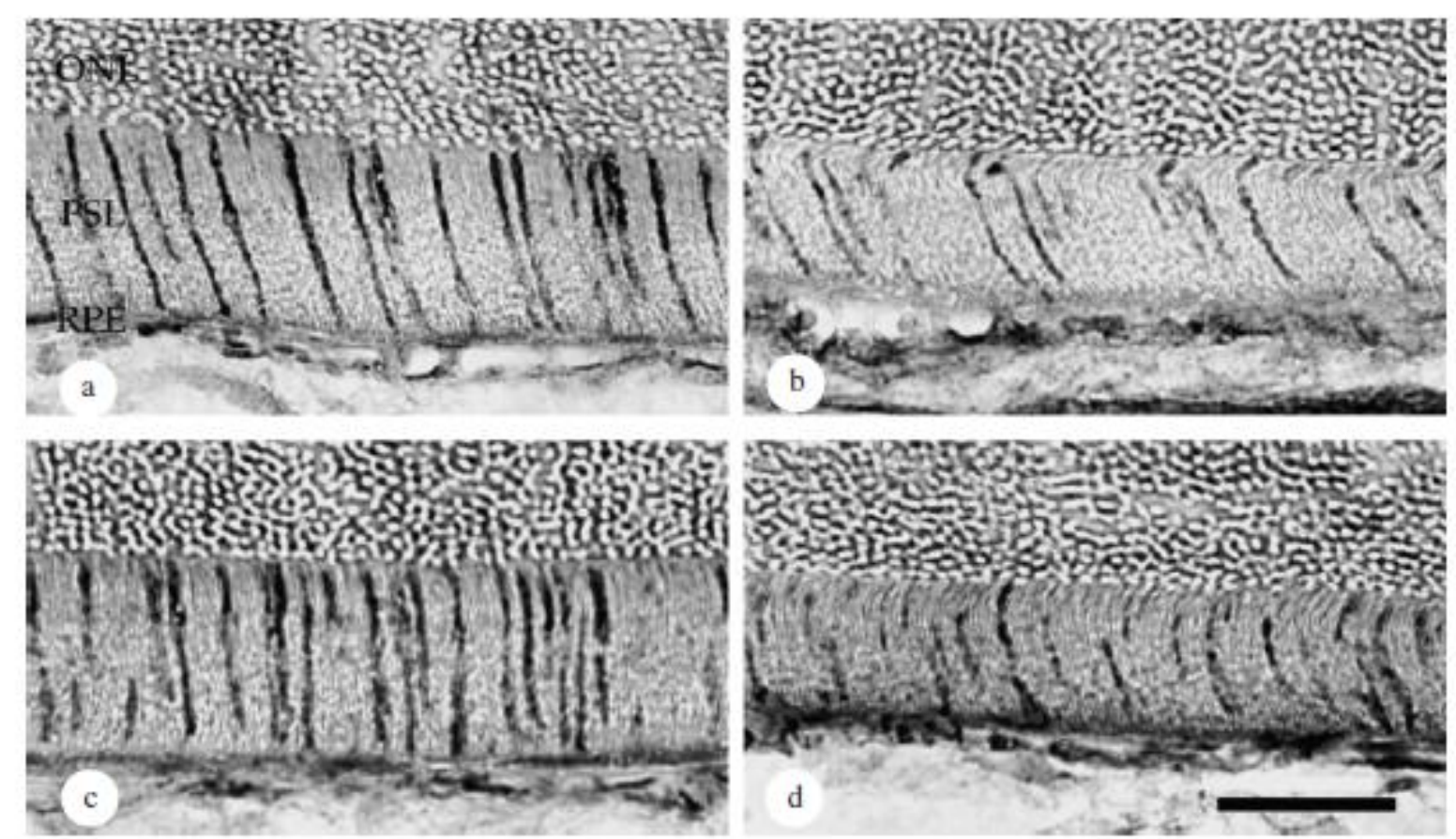

Figura 06- Imunohistoquímica com Peanut agglutinin (PNA) em retinas de ratos diabéticos e controles. As fotomicrografias mostram a diminuição do número de fotorreceptores após um (b) e seis meses (d) de doença em ratos, em comparação com sujeitos controles. Legenda: ONL- Camada Nuclear Externa; PSL: Camada de fotorreceptores; RPE: Epitélio Pigmentar. A barra à direita representam 40 $\mu \mathrm{m}$ em escala. Extraído de: AIZU ET AL (2002).

Em estudo com pacientes diabéticos tipo 1, Garcia (2012) encontrou diminuição de amplitude e aumento do tempo implícito no resultado do eletrorretinograma multifocal, em comparação com sujeitos controles. Da mesma forma, o mesmo estudo mostrou redução na discriminação cromática destes mesmos pacientes. Gualtieri (2008) também encontrou perdas difusas (nos três eixos de confusão de cores) na discriminação cromática de pacientes diabéticos tipo 2, bem como aumento de latência e redução de amplitude em resultados do eletrorretinograma multifocal. Tais estudos encontraram alterações mesmo em pacientes que não apresentavam RD. Ou seja, tais resultados vão ao encontro do trabalho de Aizu e colaboradores (2002), no que se refere a achados clínicos que coadunam com os encontrados nos ratos diabéticos por streptozotocina.

Células ganglionares são as mais vulneráveis para sofrer apoptose na retina; as células gliais parecem possuir um papel importante na indução de apoptose nas células ganglionares (EL-ASRAR ET AL, 2004). A hiperglicemia parece ter um efeito de indução à apoptose nas células da retina; mas este efeito não parece atingir a glia e do epitélio pigmentar, o que por sua vez, leva a uma maior indução de morte em outras células neurorretinais (EL-ASRAR ET AL, 2004). A figura 7, abaixo, mostra a ativação das células da glia em ratos com quatro semanas de diabetes induzida. Os astrócitos também diminuem a expressão de proteína ácida fibrilar glial (GFAP, do inglês, glial fibrillary acidic protein), que está diretamente relacionada com o estado funcional da própria célula 
(GARDNER ET AL, 2002). Injeções de insulina podem reverter tal quadro, se há pouco tempo de instalação da doença, o que reforça a hipótese de que os astrócitos são fortemente influenciados pela taxa glicêmica (GARDNER ET AL, 2002).

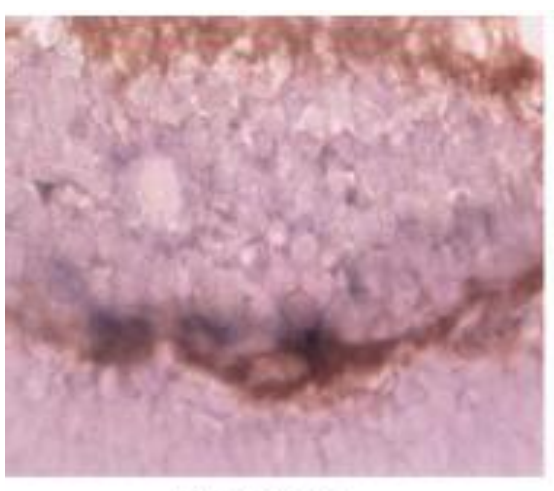

Normal

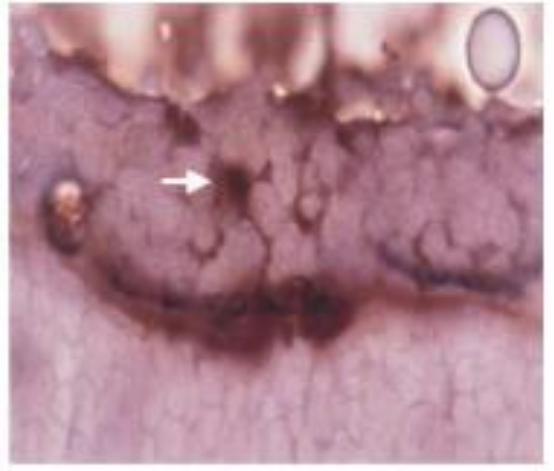

Diabetes

Figura 07- Ativação de células da glia em rato com quatro semanas de diabetes induzida. Nota-se o escurecimento da região, bem como projeções (vilosidades) na camada de células ganglionares. Aumento original de 600 X. Extraído de: GARDNER ET AL, 2002.

\subsection{O Papel da Eritropoietina no Desenvolvimento da RD}

Um dos fatores cuja associação com a RD vem sendo estudada é a Eritropoietina (EPO). A descoberta de que tal hormônio glicoproteico possui receptores em outros tecidos que não os do sistema hematopoiético levou ao estudo e à compreensão de outras funções fisiológicas dessa substância (MAIESE, LI \& CHONG, 2005). Durante o desenvolvimento fetal, tal proteína é produzida no fígado; após o nascimento, ela passa a ser produzida pelos rins (JELKMANN, 1992). A EPO previne a apoptose de células precursoras eritroides, bem como atua na proliferação e diferenciação das mesmas em normoblastos; desta forma, a eritropoiese aumenta ao suprimento de oxigênio disponível para o tecido (JELKMANN, 1992). A figura 08, abaixo, mostra o processo de eritropoiese. 


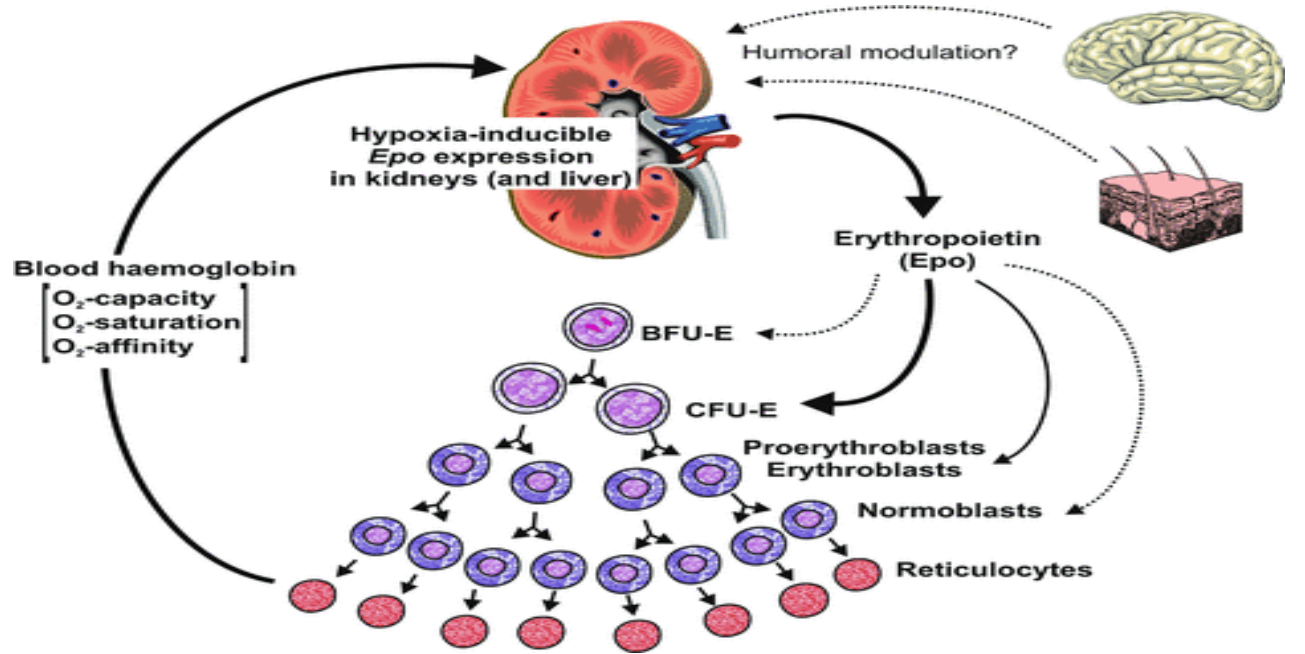

Figura 08- Diagrama de regulação de eritropoiese por feedback. Nota-se que a hipóxia leva à síntese de eritropoietina, que por sua vez, atua no mecanismo de proliferação e diferenciação de eritrócitos. O papel da regulação hormonal na eritropoiese ainda não é totalmente conhecido. Extraído de: JELKMANN, 2011.

A EPO possui expressão mediada por um gene presente no cromossomo 7, em uma região de 5,4 kb e que codifica um polipeptídeo que contém 193 aminoácidos (MAIESE, LI \& CHONG, 2005). Possui quatro cadeias glicosiladas, necessárias para prevenir possíveis danos por radicais livres. No sistema nervoso, limita a produção de moléculas nocivas aos tecidos, tais como oxigênio reativo e glutamato, bem como estimula a angiogênese e atenuação dos processos de apoptose (GENC ET AL, 2004). Embriões de camundongos knock-out que possuem receptores de EPO (EPOR, do inglês EPO receptors) defeituosos ou não funcionais morrem após alguns dias, em decorrência de diversas anormalidades, tais como hipoplasia ventricular e apoptose aumentada no fígado, coração e cérebro (GENC ET AL, 2004). A expressão de EPO é regulada pelo fator de induzido por hipóxia (HIF-1, do inglês, hypoxia-inducible factor-1) (GENC ET AL, 2004). Além disto, distúrbios metabólicos, tais como hipoglicemia ou a geração de espécies mitocondriais reativas ao oxigênio, podem aumentar a expressão de EPO; em camundongos, estresse anêmico induz a expressão do gene para receptores de EPO no tecido hematopoiético e no cérebro, assim como insulina pode estimular a expressão de RNAm para EPO em cultura de astrócitos (GENC ET AL, 2004). Tais achados sugerem que a expressão de EPO pode encontrar-se aumentada na hiperglicemia inerente à DM.

Com relação ao sistema vascular, a EPO preserva a integridade das células endoteliais e promove a angiogênese, bem como mantém a permeabilidade da barreira hematoencefálica e a manutenção das junções celulares (MAIESE ET AL, 2005). No 
entanto, em estágios mais avançados da doença, níveis elevados de EPO poderiam potencializar os efeitos de outros fatores de neovascularização, tal como VEGF, levando assim a um agravamento do quadro de RD (VILLAROEL ET AL, 2015; CHEN ET AL, 2008).

Além do rim, do fígado e do útero, outros tecidos também a secretam, tais como aqueles formados por células endoteliais periféricas, células vasculares, produtoras de insulina, músculos lisos, além do sistema nervoso e vascular (CHONG, KANG \& MAIESE, 2002; MAIESE, LI \& CHONG, 2005). No encéfalo, a maior produção de EPO concentra-se no hipocampo, no córtex, no mesencéfalo, nas células endoteliais cerebrais e nos astrócitos (GENC ET AL, 2004). Além disto, receptores de EPO estão presentes em neurônios, em células da microglia, nos astrócitos, bem como na bainha de mielina de nervos periféricos (MAIESE, LI \& CHONG, 2005); no entanto, em baixas concentrações em humanos (GENC ET AL, 2004). A concentração de RNA mensageiro para receptores de EPO é maior no epitélio pigmentar que na neurorretina; níveis intravítreos de EPO são 3,5 maior no tecido retiniano que no plasma sanguíneo (GARCÍA-RAMIREZ ET AL, 2008; VILLAROEL ET AL, 2015). Tais dados sugerem que EPO pode ser produzido endogenamente como um fator neuroprotetivo e por isto mesmo, tem sua expressão aumentada em casos de isquemia local (SHAH ET AL, 2009).

Comparados com o VEGF, a EPO está mais fortemente associada com RDP (ZHANG ET AL, 2008; SHAH ET AL, 2009). Da mesma forma, inibição na produção de EPO sistêmico foi observada na nefropatia diabética, bem como quadros de anemia foram associados com uma piora no curso da RD (COTRONEO ET AL, 2000). O estudo que traz tal conclusão avaliou 13 pacientes DM Tipo 1 com anemia, encontrando menor concentração de EPO cursando com neuropatia diabética em dez deles (COTRONEO ET AL, 2000). Há relatos de melhora de sinais clínicos associados à RD em pacientes com anemia tratados com EPO (SHAH ET AL, 2009). Em estudo post-mortem em retinas de nove pacientes diabéticos sem $\mathrm{RD}$, foram identificados níveis maiores de EPO tanto na neurorretina quanto no epitélio pigmentar em comparação com os controles (GARCÍARAMIREZ ET AL, 2008). Além disto, tais autores encontraram alterações nas células de Muller; de fato, eles apontam que ativação das células gliais e neurodegeneração são modificações que podem preceder as alterações vasculares do quadro de RD (GARCÍARAMIREZ ET AL, 2008, BARBER, 2003). Outro achado do supracitado estudo foi que a regulação de EPO não havia sido induzida por eventos isquêmicos, já que os níveis de 
fatores indutores de EPO por hipóxia foram similares em diabéticos e controles. Assim, é provável que em estágios iniciais, a isquemia não seja fator determinante no aumento do nível de EPO na retina de pacientes com DM. No entanto, Katsura e colegas (2005), ao estudar a concentração de fatores de indução de angiogênese em 59 pacientes com RD, não encontraram diferenças na concentração de EPO em pacientes anêmicos e não anêmicos. Ou seja, novamente, a hipóxia induzida pela anemia não foi considerada um fator determinante para a expressão de EPO.

Shah e colaboradores (2009) estudaram post-mortem o tecido retiniano de um paciente com RDP, com o intuito de indicar a localização dos receptores de EPO e revelaram que esses são expressos primariamente na camada de células ganglionares, sendo que, em condições normais, não há expressão nos fotorreceptores. Os pesquisadores ainda sugerem haver expressão de EPO nos fotorreceptores durante a RD, em decorrência da alta taxa metabólica de tais células, o que as deixariam mais suscetíveis à hipóxia.

Àsensio-Sanchez e colegas (2008) determinaram a concentração de EPO no vítreo de pacientes com RDP e compararam com níveis em pacientes não diabéticos. No grupo caso, os níveis encontrados foram de $512 \mathrm{mU} / \mathrm{mL}$ contra 25,1 mU/mL para controles. Igualmente, Hernandéz e colaboradores (2006) encontraram concentrações vítreas de EPO 30 vezes maiores que no plasma sanguíneo. Watanabe e colegas (2005) obtiveram valores semelhantes: $464 \mathrm{mu} / \mathrm{mL}$ para concentração de EPO no vítreo de pacientes com RDP, em contraposição a $36,5 \mathrm{mu} / \mathrm{mL}$ em não diabéticos. Da mesma maneira, alguns estudos indicam que a proliferação de células endoteliais na retina de pacientes com RDP ocorre relacionada à EPO de maneira dose-dependente (CHOW ET AL, 2001; ÁSENSIO-SANCHEZ ET AL, 2008).

Diversos trabalhos apontam que apesar do papel do VEGF na angiogênese, a inibição de fator não é suficiente para mitigar a formação de neovasos, o que sugere, portanto, que haja outros reguladores locais modulando a ação deste fator. Watanabe e colaboradores (2005) procuraram medir o nível de EPO e de VEGF em pacientes com RDP, mostrando que ambos se encontravam elevados no vítreo de pacientes com RDP. No entanto, tais fatores estavam associados de maneira independente com a RD, sendo a EPO mostrou uma maior relação com a RD que o VEGF. Cabe ressaltar que os autores de tal estudo referiram não encontraram correlação entre a concentração vítrea e o nível plasmático da substância estudada, propondo então que o aumento de EPO ocorra apenas localmente. Além disto, o estudo citado também encontrou que o bloqueio da expressão de 
EPO levou à inibição de neovascularização e de proliferação das células endoteliais na retina, tanto in vivo quanto in vitro, o que corrobora a hipótese de que a EPO está relacionada ao processo angiogênico na RDP.

Grimm e colegas (2002) mostraram que quando camundongos são deixados em ambiente com baixa concentração de oxigênio durante seis horas, a morfologia e a função dos fotorreceptores permanecem preservadas mesmo após serem expostos à iluminação intensa (o que causa degeneração de tais células). Desta forma, sugere-se que a hipóxia inibiu a expressão enzimática de caspase-1, tida como uma proteína básica para o desencadeamento do processo de apoptose. Hipóxia induz a expressão do fator 1a, que por sua vez, desencadeia a transcrição de genes envolvidos com a adaptação à menor quantidade de oxigênio, entre eles, o gene EPO. Além disto, nestas condições, a expressão de EPO aumenta na retina e experimentos imunohistoquímicos dos segmentos internos dos fotorreceptores mostraram resultados compatíveis com a hipótese de ação neuroprotetora atribuída a tal hormônio (BECERRA, 2002). Apesar do possível efeito neuroprotetivo atribuído à EPO, assim como a associação entre este hormônio e a RD, ainda não se conhecem os mecanismos bioquímicos que controlam a expressão proteica e o possível dano causado na morfologia das células de pacientes diabéticos. Assim, a expressão aumentada de fatores de crescimento vascular que possivelmente possuem efeito protetor sobre as células da retina podem estar relacionada a mecanismos bioquímicos que visam, inclusive, prevenir a apoptose e morte dos componentes mais importantes locais.

Gholamhossein e colaboradores (2014) compararam níveis plasmáticos de EPO em 180 pacientes em vários estágios de $\mathrm{DM}$ e de $\mathrm{RD}$ e encontraram associação entre a concentração de EPO e a gravidade da doença, sugerindo então haver uma relação entre tais níveis e o desenvolvimento de RDP. Estes autores também indicaram que a correção do nível plasmático de EPO em pacientes com RD pode reduzir o risco da forma proliferativa da doença para até $1,17 \%$. No entanto, tais autores também discutem que tais resultados contrariam outros trabalhos da área, como os de Watanabe e colegas (2005), que mostraram que a associação entre alta concentração de EPO e RDP ocorre relacionada à concentração no vítreo e não no plasma, já que há uma dúvida se este hormônio, com 40 $\mathrm{kB}$, seria capaz de atravessar a barreira hematoretiniana. No entanto, há trabalhos que indicam que a EPO recombinante é capaz de atravessar a barreira hematoencefálica, em casos nos quais há danos cerebrais (BRINES ET AL, 2000). 
Shen e colegas (2014) estudaram os efeitos da EPO em ratos com retinopatia, injetando o hormônio intraperitonealmente em animais com e sem disfunções vasculares durante um mês. Os animais mostraram regressão dos capilares formados e estabilização vascular, acompanhada de gliose na retina. Além disto, os autores também citaram a inibição de lesões vasculares focais, estimulação da produção de VEGF e diminuição da apoptose de fotorreceptores. Tal estudo apontou, portanto, um possível efeito terapêutico da EPO na RD. No entanto, reiteram que a expressão aumentada tanto de EPO quanto de VEGF local pode aumentar ainda mais as complicações inerentes à doença. Ou seja, a questão não seria o aumento em si de hormônio circulante, mas sim a quantidade alta deste na retina. Da mesma forma, tais mecanismos protetivos seriam regulados por uma série de mecanismos, ainda não de todos desvendados.

\subsection{SNPs para Expressão de EPO e sua Relação com RD}

A expressão de EPO é influenciada por polimorfismos de único nucleotídeo (SNPs-do inglês, Single Nucleotide Polymorphisms) localizados no Cromossomo 7q21. Estudos indicam que há uma associação entre a expressão aumentada de EPO e determinados SNPs, que são tidos como possíveis influências na suscetibilidade para o desenvolvimento da RD (TONG ET AL, 2008; MOEMEN ET AL, 2013). Entre estes candidatos, os que mostraram maior associação com RD na literatura recente foram rs1617640, rs507392 e rs551238, com maior significância apontada para o primeiro deles. O alelo T para o SNP rs1617640 é associado com maiores concentrações de EPO em olhos de diabéticos, sendo apontado como um fator de risco para o desenvolvimento de RDP (TONG ET AL, 2008).

No entanto, a relação entre determinados SNPs e a susceptibilidade a certas doenças ainda permanece incerta. Kanková e colaboradores (2007) investigaram potenciais associações entre 45 SNPs em 20 genes candidatos para nefropatia diabética (ND). Para tanto, tal estudo contou com 647 participantes, sendo 235 com nefropatia diabética e 184 diabéticos sem a doença. Apenas um SNP, presente no gene codificador para AGE mostrou significância para a análise de locus único; porém, na análise de locus múltiplos, seis SNPs dos cromossomos 6 e 7 mostraram-se associados com ND. A nefropatia diabética é uma microvasculopatia do DM e apresenta alta correlação com RD (TONG ET AL, 2008). Assim, Tong e colaboradores genotiparam 19 SNPs em 11 genes relacionados a fatores 
angiogênicos em 374 pacientes com diagnóstico de RD e ND. De todos os SNPs envolvidos, os autores encontraram associação para o rs1617640. Da mesma forma, em associação com este SNP, os autores encontraram associados os polimorfismos rs507392 e rs551238, formando os três SNPs o haplótipo TTA como genótipo de risco. O mesmo artigo também traz que os SNPs rs734908 e rs4729607 também se encontraram associados com maior incidência das doenças investigadas. Tal estudo foi replicado pelos autores em duas coortes de diabéticos tipo 1 (1244 pacientes com e sem ND e 715 diabéticos sem complicações), e foram encontrados os mesmos resultados.

Já Moemen e colegas (2013) investigaram 100 diabéticos, sendo 60 com RDP e 40 com RDNP e encontraram associação entre RDP e os três SNPs citados pela equipe de Tong (rs1617640, rs507392 e rs551238). No entanto, diferentemente de Tong, tais autores encontraram o haplótipo GCC como fator de risco para RD, independente da duração da DM, bem como do controle glicêmico. Estes resultados discrepantes na literatura são chamados de fenômeno de "flip-flop" e podem ocorrer quando apenas um locus é associado com a doença, mas sob a presença de efeitos de diversos outros loci, o que pode gerar confusões (LI ET AL, 2004). Além disto, Moemen e colegas também consideram a variação entre as amostras que compõem tais estudos, já que se trata de diferentes etnias e, portanto, a distribuição dos padrões de linkage disequilibrium são diferentes, podendo influenciar os resultados.

Abhary e colaboradores (2010) genotiparam 518 diabéticos, sendo 173 com o tipo 1 da doença e 345 com o tipo 2. Dentre a amostra, 155 participantes apresentavam RDNP e 126, RDP. Da mesma forma, os autores encontraram o haplótipo GCC associado com maior incidência de $\mathrm{RD}$, especialmente entre os $\mathrm{DM}$ tipo 2. Tong e colegas investigaram amostras de diabéticos tipo 1, diferentemente de Abhary e colaboradores. Além disto, no estudo da equipe de Tong (2008), foram incluídos pacientes com ND em estágio terminal e embora os processos patogênicos da RD e da ND sejam semelhantes, pode ser que haja diferentes fatores genéticos envolvidos no desenvolvimento destas doenças (MOEMEN ET AL, 2010). Por isto, é possível que cada um dos trabalhos identificou variações do gene EPO responsáveis apenas por uma ou outra doença, o que causou tal diferença entre os estudos (MOEMEN ET AL, 2008). Além disto, os trabalhos que associaram a concentração de EPO com a RD mostraram associação com o aumento local do hormônio. Portanto, ainda não é totalmente compreendida a participação gênica na incidência de tal patologia. 
Outro estudo realizado com 500 pacientes DM tipo 2, sendo 216 com RD, procurou avaliar associação entre 26 SNPs de 18 genes candidatos para RD (YANG ET AL, 2014). Assim, tais resultados obtidos mostraram associação entre quatro SNPs (rs699947, rs833061, rs13207351 e rs2146323) para o gene VEGF e um para o gene KDR (do inglês, Kinase Insert Domain Receptor), também chamado de receptor para VEGF (rs2071559). Além disto, tal grupo de pesquisadores também avaliou os polimorfismos rs1617640, rs507392 e rs551238 do gene EPO, não encontrando associação entre os mesmos e o diagnóstico de RD. Interessantemente, tal associação mostrada em outros estudos não se confirmou no trabalho supracitado, o que pode denotar uma ainda não conhecida relação da expressão gênica com fatores ambientais ou até mesmo com outros genes.

Em trabalho de Hoisseini e colaboradores (2014), foi realizada uma meta-análise para comparar a associação entre sinais prévios de RD e ND e genes candidatos. Tal trabalho levou em consideração dados de estudos de associação para genoma amplo (GWAS, do inglês, Genome-Wide Association Studies). Neste tipo de análise, SNPs do genoma inteiro são testados, visando uma possível associação com determinada doença. Os SNPs rs1571942 e rs12219125 mostraram significativa relação com RDNP. Já o SNP rs1617640 não foi associado com a progressão da RD, resultado que vai de encontro àqueles encontrados em outras pesquisas. Contrariando os resultados de Tong e colaboradores (2008), tal SNP não foi associado também com o diagnóstico de ND sem RD. Os autores tentam explicar tal discrepância explicando que alguns destes trabalhos levaram em consideração apenas pacientes com o tipo 1 de DM, enquanto outros estudaram diabéticos tipo 2. Apesar de não haverem diferenças na patofisiologia de ambos os quadros, pode ser que algum tipo de associação ocorra entre o genótipo e cada um dos tipos da doença. Outras variantes genéticas ainda não totalmente conhecidas podem ainda se relacionar com a RD, o que causaria tais discrepâncias nos estudos realizados. Da mesma forma, Balasubbu e colaboradores (2010) examinaram nove genes candidatos (RAGE, PEDF, AKR1B1, EPO, HTRA1, ICAM, CFH, ARMS2 e HFE) para associação com RD. Para tanto, genotiparam 345 pacientes diabéticos sem RD e 356 pacientes com RD. Desses genes, apenas o SNP rs2070600 mostrou associação com RD. Novamente, não foram encontradas associações entre o SNP rs1617640 e a presença de Retinopatia Diabética. Em estudo multicêntrico, Sobrin e colegas (2011) avaliaram 2691 diabéticos para 2000 genes candidatos. Os autores encontraram associação para o SNP rs551238, com 
dados consistentes àqueles obtidos por Tong e colaboradores (2008). No entanto, tal associação não se manteve pelo método de Bonferroni e por isto, não foi considerada significativa.

Tendo em vista tais discrepâncias, Cho e Sobrin (2014) procuraram realizar uma síntese dos achados dos diversos trabalhos que versaram sobre a base genética para RD. Assim, as autoras escrevem que apesar da rápida expansão das pesquisas sobre as variantes gênicas da Retinopatia Diabética nos últimos 20 anos, os dados ainda são discrepantes. Trazem como possíveis explicações para este fato desde discrepâncias no que são considerados sinais de RD e diferentes considerações acerca da duração da DM, até tamanhos inadequados de amostras. O papel de fatores genéticos na susceptibilidade para RD é amplamente aceito graças a estudos que mostram que irmãos e parentes de pacientes com RD possuem um risco de duas a três vezes maior de desenvolver a doença (THE DIABETES CONTROL AND COMPLICATIONS TRIAL RESEARCH GROUP, 1997). Os trabalhos iniciais nesse campo procuravam examinar a base genética dos traços patológicos através da análise de ligação (linkage analysis) entre familiares; tal estratégia procura mapear regiões genômicas com um número maior de alelos compartilhados entre os diversos membros afetados de uma mesma família (CHO \& SOBRIN, 2014). Tais estudos mostraram resultados inconsistentes, já que não possui um desenho adequado para pesquisas que envolvem doenças poligênicas, tais como a RD (CHO \& SOBRIN, 2014).

A maior parte dos estudos relacionados à RD são estudos de associação entre genes candidatos, que comparam a frequência de variantes genéticas entre participantes com e sem a doença estudada. Assim, genes que poderiam estar relacionados a fatores angiogênicos relacionados à DR, tais como VEGF, aldose redutase, AGE e EPO são investigados; no entanto, ainda não foram encontradas associações consistentes com estes estudos (CHO \& SOBRIN, 2014). Para tanto, Cho e Sobrin (2014) apontam que o estudo de Tong e colaboradores (2008) contou com uma grande amostra de pacientes com RDP (relacionada com maior herdabilidade genética), além de uma rigorosa avaliação do grupo controle, considerando pacientes com pelo menos 15 anos de DM sem RD, apesar dos resultados serem discrepantes daqueles encontrados por Abhary e colegas (2010). São apontadas como possíveis razões para tais achados: tamanhos insuficientes de amostra para detectar efeitos mais modestos, falta de uma cobertura mais abrangente acerca dos genes envolvidos, bem como hipóteses errôneas sobre o papel de determinados fatores no desenvolvimento da doença. A farmacogenética é apontada como um campo promissor na 
descoberta de tais associações, já que trazem correlações entre as variáveis clínicas e os diversos fatores angiogênicos.

Já em estudo empreendido por Song e colegas (2015), 792 diabéticos tipo 2 foram genotipados para os SNPs rs1617640, rs507392 e rs551238, sendo 448 participantes com RD (220 com a forma proliferativa da doença). Apesar de não ter sido encontrada associação com relação ao primeiro SNP, os alelos CC para os outros dois foram associados com uma menor incidência de RD, o que corrobora os dados de Tong (2008). O SNP rs551238 está localizado no locus 3'-HRE (elemento respondente à hipóxia-do inglês, hypoxia-responsive element), próximo a locais promotores de expressão de fatores de hipóxia, sendo então, um importante SNP no que se refere à regulação de respostas á baixa concentração de oxigênio. Porém, não foram encontradas associações relacionadas ao rs1617640, região promotora do Gene EPO e apontada em outros trabalhos.

Thorsen e colegas (2015) genotiparam 130 pacientes para 20 diferentes SNPs. Os autores encontraram a variante alélica C para o SNP CTSH/rs3825932 associada a um risco reduzido de progressão de RDP. Já a variante G para o SNP ERBB3/rs2292239 foi associada a um risco aumentado de progressão da doença. Estudos indicam que o gene CTSH possui um papel importante no desenvolvimento da DM tipo 1 e está diretamente relacionado a proteínas expressas nas células $\beta$ das ilhotas pancreáticas (THORSEN ET AL, 2015). O gene ERBB3 também é associado com o desenvolvimento de DM tipo 1, sendo que menores níveis de RNA mensageiro para ele foi relacionado a um maior risco para o desenvolvimento da doença.

O rs1617640 também foi associado com outras condições clínicas. Amanzada e colegas (2014) investigaram a associação entre o genótipo para tal SNP e a concentração plasmática de EPO antes e durante a terapia antirretroviral em pacientes com hepatite crônica. Um dos possíveis efeitos da terapia com Interferon e Ribavirina no tratamento de Hepatite C crônica é a diminuição na produção de hemoglobina. No trabalho supracitado, os autores dosaram o nível plasmático de EPO, relacionando-o com o genótipo para o SNP rs1617640, em 348 pacientes em tratamento com estes medicamentos. Os homozigotos $\mathrm{G}$ mostraram menores concentrações de EPO plasmático que os de alelo T, além disto, mostraram-se mais propensos à necessidade de reduzir a dose do medicamento ou de ter que dar início à terapia de suplementação com EPO 
5. VISÃO DE CORES 


\subsection{Visão Geral}

$\mathrm{Na}$ espécie humana, as ondas eletromagnéticas são visíveis a olho nu, em forma de luz, na faixa compreendida entre 380 e $760 \mathrm{~nm}$. Newton (1643-1727), ao estudar a natureza das ondas que compõem o espectro visível, decompôs a luz branca em sete diferentes cores fundamentais (vermelho, laranja, amarelo, verde, azul, anil e violeta), sendo que a mistura destes diferentes elementos espectrais é que seria responsável por criar o mundo com seus diversos matizes (Figura 09). Aristóteles já postulava a existência de cores fundamentais (vermelho, amarelo, verde, azul, branco e preto), no entanto, acreditava que a coloração fosse uma característica inerente ao próprio objeto. No Renascimento, esta ideia foi refutada, aceitando-se na época a noção de que a cor é uma propriedade da luz.

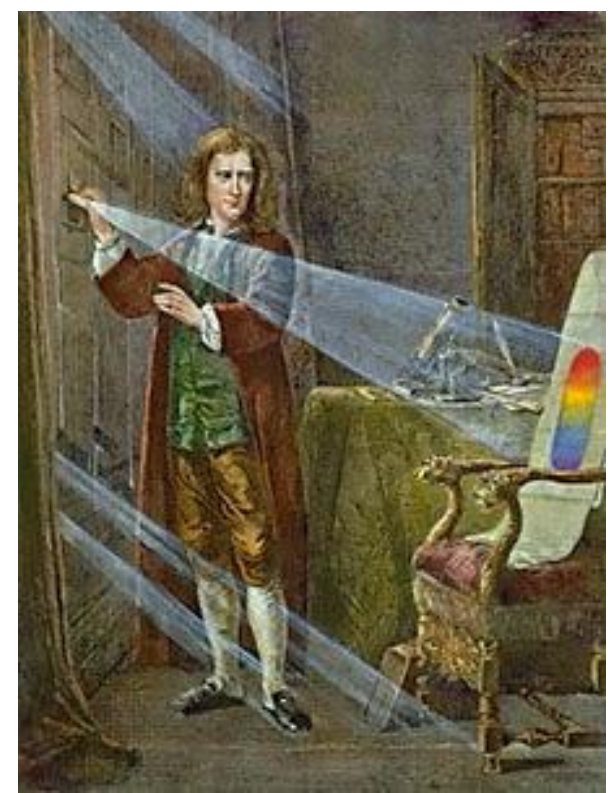

Figura 09- Experimento de Newton demonstrando a decomposição da luz solar no espectro de cores fundamentais. Fonte: The Illustrated London News, 04 de Junho de 1870. Extraído de : http://www.biografiaisaacnewton.com.br/ 2013/12/Experimentos-de-Isaac-Newtonestudos-com-a-Optica.html.

Atualmente, a luz é vista como tendo uma natureza dual: ao mesmo tempo em que é uma onda eletromagnética, também se comporta como partícula, como um pacote de energia denominado fóton. Usualmente, quando se avalia a sensibilidade do sistema visual à luz como um todo, ela é tida como uma partícula. No entanto, ao se avaliar a percepção de cores, leva-se em consideração a natureza ondulatória da luz, com o vermelho na faixa 
de comprimento de onda longo e o azul na faixa de comprimento de onda curto (TOVÉE, 2008; vide Figura 10). A percepção de cor inicia-se na retina, através da absorção de luz pelos fotorreceptores. Desta forma, acreditava-se à época que haviam na retina cones respondentes para cada uma das cores vistas, cada um delas codificando certo comprimento de onda. No entanto, descartou-se tal teoria justamente pelo fato de que existem milhares de cores percebidas pelo ser humano e, portanto, seria inviável que houvessem tantos tipos diferentes de cone na retina.

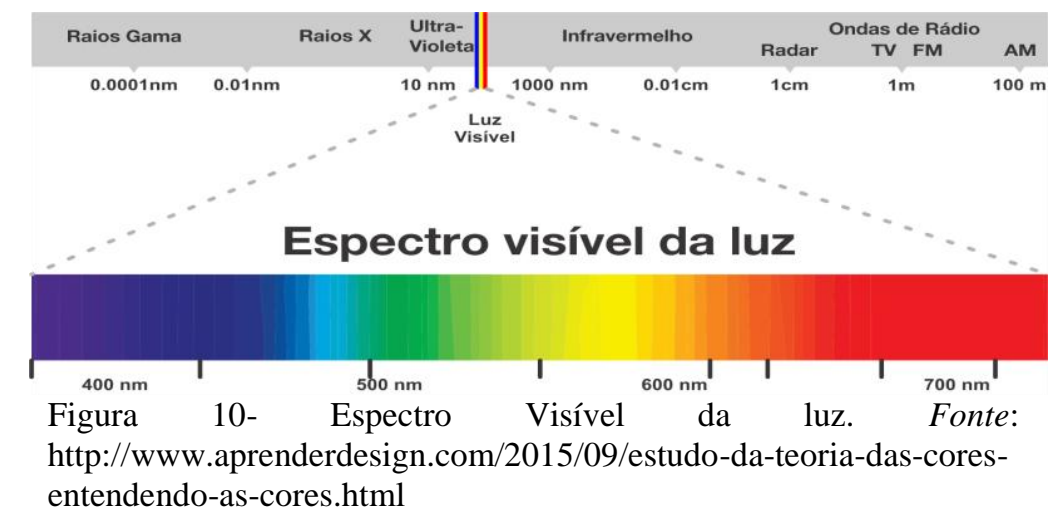

Em 1802, Thomas Young propôs que a detecção de diversas cores é possível porque o olho humano possui três tipos de fotorreceptores, com diferentes sensibilidades espectrais. Tal teoria foi denominada de tricromática. Assim, as cores visíveis seriam reproduzidas por diferentes proporções de três cores básicas (vermelho, verde e azul). No entanto, a teoria de Young não era capaz de explicar fenômenos ópticos, tais como contraste simultâneo, e nem como o amarelo é visto também como cor primária, e não como uma mistura de outras cores. Complementando as ideias de Young, Ewald Hering propôs que a discriminação de cores acontece através de canais de oponência, através dos quais as respostas dos diferentes tipos de cone são comparadas entre si. Desta forma, uma pessoa que possuísse apenas um dos cones não seria capaz de visualizar qualquer cor, pois não teria como existir comparação entre elas. Assim, há uma atividade relativa de canais de oponência entre as cores vermelho-verde, azul-amarelo, bem como de brilho relativo (SCHWARTZ, 2004).

Atualmente, tanto a teoria de Young quanto a de Hering são aceitas para explicar a maior parte dos fenômenos que acontecem na visão de cores, ou seja, trabalha-se com a noção de que a visão é tricromática e que o processamento processual acontece tanto na retina quanto no córtex cerebral (núcleo geniculado lateral). Tal antagonismo, que gera os canais de oponência, inicia-se nas células bipolares. Necessita-se, portanto, de pelo 
menos dois tipos de cones para que cor seja percebida, bem como de um substrato neural que compare os sinais emitidos por tais células. Ou seja, enquanto que a teoria de Young relaciona-se com os fotorreceptores, é na teoria de Hering que a interpretação da visão pós receptoral irá apoiar-se (BONCI, 2011).

Cada molécula de fotopigmento consiste em um cromóforo e uma opsina. $\mathrm{O}$ cromóforo (retinal) é um aldeído derivado do retinol e é ele quem absorve os fótons, dando início à cascata de eventos que culminam na visão humana. A opsina, que é uma cadeia de aminoácidosinterligada às membranas do segmento externo da retina, determina as características de absorção da luz de cada fotorreceptor, sendo, portanto, diferente para cada classe de cones. Os cones são divididos em três tipos, conforme o tipo de opsina presente. A rodopsina, presente nos bastonetes, é sensível à faixa espectral de aproximadamente $500 \mathrm{~nm}$, o que corresponde à cor azul. O que difere cada tipo delas é a variação na sequência dos aminoácidos que a compõem. As opsinas são determinadas geneticamente, sendo que as opsinas dos cones-L (na faixa espectral do vermelho) e dos cones-M (na faixa do verde) são determinadas por genes encontrados no cromossomo X. Já aquelas presentes nos cones-S (faixa do azul) são expressas por um gene no cromossomo 7 e as rodopsinas (pigmentos dos bastonetes) são codificadas por um gene do cromossomo 3 . A figura 11 mostra cones e bastonetes presentes na retina murina.

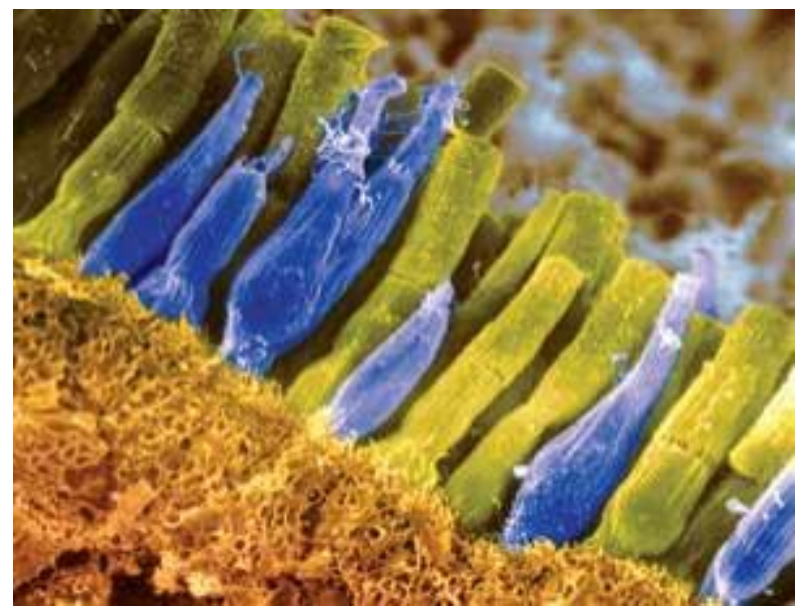

Figura 11- Cones (em azul) e bastonetes (em verde) presentes em retina murina. Coloração retocada por software. .Extraído de: www.newscientist.com, Retinal cone cells transplanted into blind mice. Acesso em 22 de Setembro de 2010.

Na retina, existem dois tipos de fotorreceptores: os cones, responsáveis pela visão fotópica ou diurna (em condições de boa iluminação) e os bastonetes, responsáveis pela visão escotópica ou noturna (em condições de penumbra). Enquanto que os bastonetes 
possuem alta capacidade de absorção de fótons, mas baixa acuidade visual, os cones possuem excelente acuidade visual, mas com menor sensibilidade à luz. Na retina humana, ambas os tipos de células distribuem-se de maneira desigual, sendo que a fóvea possui a maior concentração de cones, não tendo bastonetes em sua região. A figura 12 mostra a densidade de cones e bastonetes na retina humana, em relação à distância da fóvea, local de maior acuidade visual. A retina também possui um número desigual dos dois tipos de célula: há cerca de 125 milhões de bastonetes e apenas oito milhões de cones.

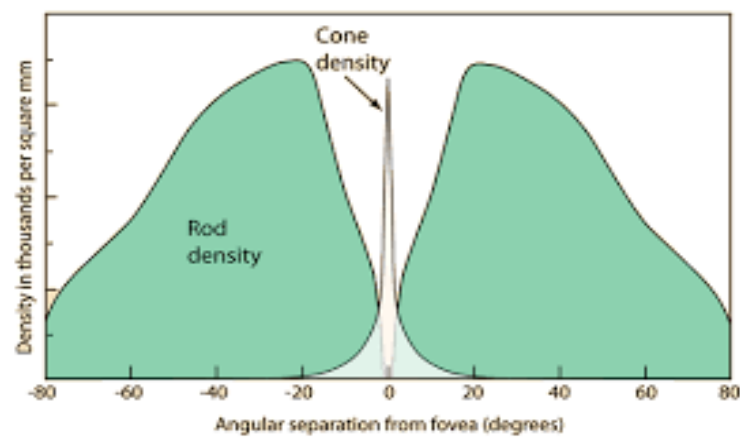

Figura 12- Densidade (milhões por $\mathrm{m}^{2}$ ) de cones e bastonetes em relação à distância da fóvea. Extraído $d e$ : www.hyperphysics.phy-astr.gsu.edu

A luz, ao atingir a retina, estimula os fotopigmentos dos cones e dos bastonetes. Cada disco no segmento externo do bastonete possui milhares de moléculas de rodopsina, que traduzem a energia luminosa em química. A rodopsina sofre uma isomerização ao ser atingida pelo fóton, passando de sua forma 11-cis para a forma ativa trans-retinal. A cascata bioquímica de eventos que ocorre a partir deste momento leva à hiperpolarização da membrana. Desta forma, a "corrente escura" que libera glutamato na fenda sináptica, impedindo a célula de responder é cessada, o que leva às respostas elétricas das células bipolares e ganglionares. Essas, por sua vez, possuem a atividade mediada pelas camadas de células horizontais e amácrinas. A transdução do sinal luminoso nas opsinas dos cones ainda não é totalmente compreendida; no entanto, postula-se que ocorra de maneira semelhante que na rodopsina, já que possuem configuração proteica semelhante (HISATOMI ET AL, 2002).

Os axônios das células ganglionares formam o nervo óptico, que se dirige para o Núcleo Geniculado Lateral, no tálamo. De lá, duas vias de processamento neural são possíveis: a camada magnocelular, responsável pela detecção de movimento e a camada parvocelular, através da qual é possível obter informações sobre o contraste cromático em alta resolução (LIVINGSTONE \& HUBEL, 1984). Tais vias fazem conexão com o córtex 
visual primário, que envia suas projeções para córtex visual extraestriado e para outras áreas corticais superiores.

A maioria dos mamíferos são dicromatas; no entanto, primatas do novo mundo e humanos, são tricomatas. Ou seja, possuem um tipo de bastonete e três tipos de cones, com picos de sensibilidade espectral que variam em aproximadamente $560 \mathrm{~nm}$ para o cone-L, em $\sim 530 \mathrm{~nm}$ para o cone-M e $\sim 420 \mathrm{~nm}$ para o cone-S. A Figura 13 mostra a curva de absorção espectral para as quatro classes de fotopigmentos em humanos tricromatas.

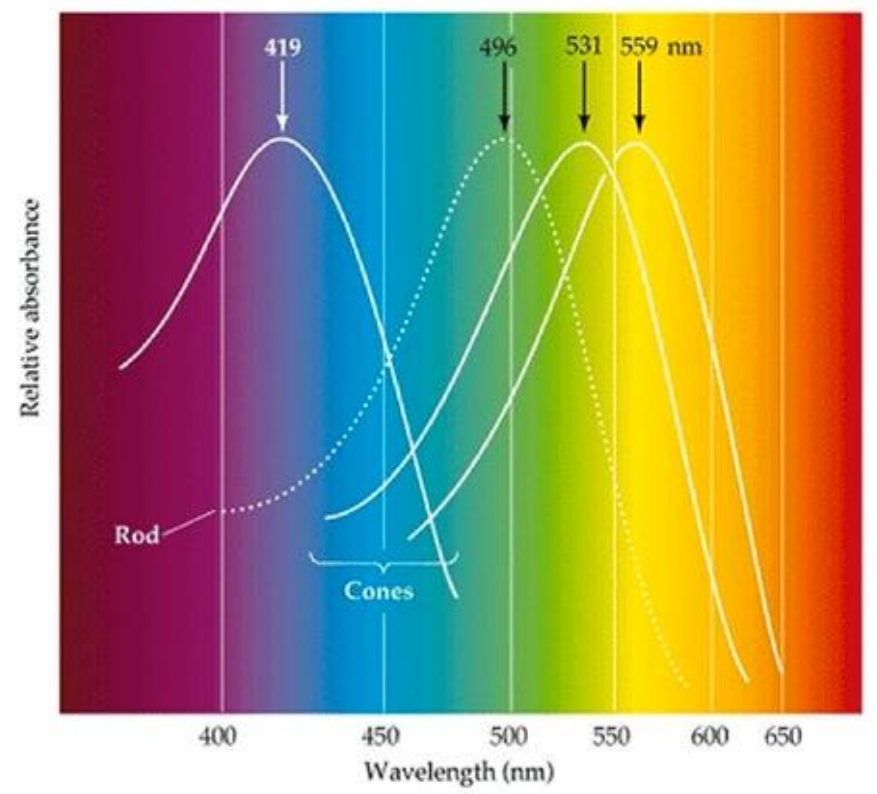

Figura 13- Curva de absorção espectral para os três tipos de cone e para os bastonetes encontrados na retina de humanos tricromatas. $\mathrm{O}$ comprimento de onda de máxima absorção em $419 \mathrm{~nm}$ corresponde ao cone-S, bem como em $531 \mathrm{~nm}$ refere-se ao cone-M e em 559 nm, ao cone L. Extraído de: http://webvision.med.utah.edu/book/part-ii-anatomy-andphysiology-of-the-retina/photoreceptors/).

\section{2 . Espaço de Cores}

A visão de cores envolve não apenas mecanismos discriminatórios fisiológicos, mas também componentes que permitem a nomeação e o reconhecimento das diferentes cores. Dentre as diferentes cores, há diferenças de tonalidade e de brilho que tornam possíveis as diferentes combinações que compõem o universo de cores. Desta forma, ao se trabalhar com aspectos que envolvem a classificação de cor, é importante fazê-lo dentro de um 
sistema que permita descrevê-las de maneira mais sistemática. O Sistema de Aparência de cor de Munsell permite, por exemplo, distinguir as cores através de três diferentes dimensões: matiz, cromaticidade e brilho. A matiz refere-se ao comprimento de onda emitido pelo estímulo, enquanto que a cromaticidade está relacionada à pureza e à saturação da cor, ou seja, quanto mais saturada, mais pura a cor. Já o brilho quantifica a refletância do comprimento de onda do objeto. Desta forma, o sistema de Munsell é composto de um cilindro contendo diversas amostras de cor (Figura 14), arranjadas de forma a mostra as matizes possíveis ao longo do perímetro do cilindro, a saturação medida a partir do centro pelo raio e o brilho partindo do ponto mais baixo das ordenadas.

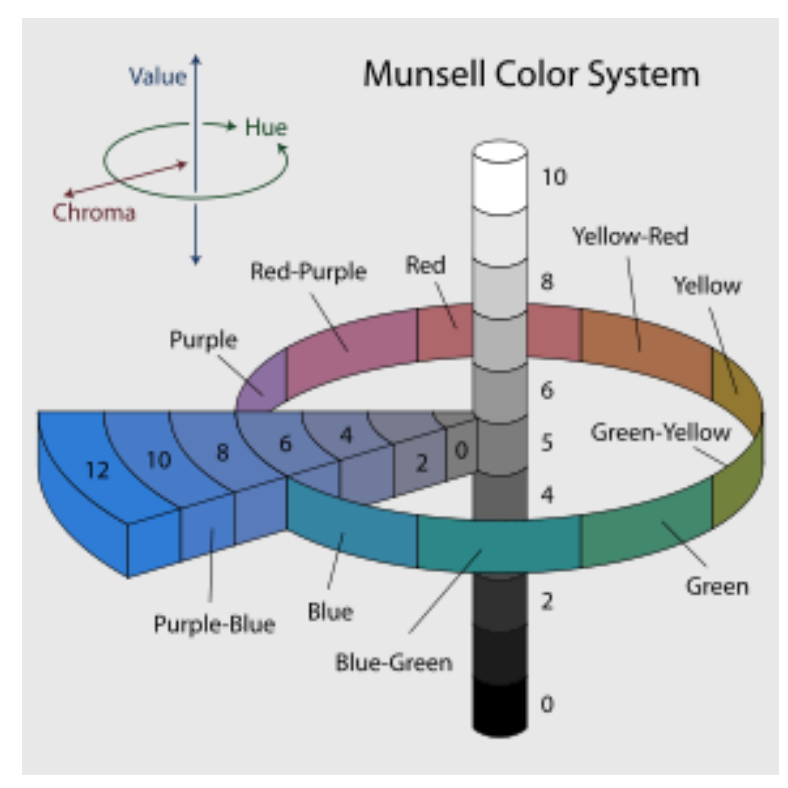

Figura 14- Diagrama de Cores de Munsell.. O matiz está representado no perímetro do cilindro. Já a saturação é medida a partir do centro, tendo valores compreendidos entre 0 e 12 . O brilho é representado como uma dimensão vertical, podendo variar entre 0 e 10 . Extraído de: https://pt.wikipedia.org/wiki/Sistema_de_cores_de_Munsel 1.

Porém, no estudo da visão de cores, o sistema mais utilizado é o Diagrama de Cromaticidade CIE, que se baseia na premissa de que a cor é especificada por quantias relativas de cada uma das três fontes primárias. Desta forma, tal sistema é uma representação matemática (não real) das quantias de cada cor presentes em um estímulo visto. Desta forma, a partir de estímulos ideais, evitam-se valores negativos para qualquer um dos matizes primários. Os comprimentos de onda das cores tidas como primárias são $645 \mathrm{~nm}$ para o vermelho, $526 \mathrm{~nm}$ para o verde e 444nm para o azul (SCHWARTZ, 2004). 
Tal sistema de cores é conhecido como RGB (do inglês, red-green-blue). O estímulo é considerado em comparação com as três cores primárias, cujas quantidades são ajustadas até a obtenção de um pareamento completo entre a mistura de cores e o estímulo real. A quantidade de cada cor primária necessária para formar a matiz de um estímulo é denominada como valor triestímulo.

Através de cálculos de álgebra linear, tais funções no sistema RGB são transformadas para o eixo das coordenadas triortogonais (abscissa, ordenada e altura, respectivamente). Desta maneira, o diagrama mostra a quantidade relativa de cores primárias necessárias para representar uma determinada cor. Assim, o valor triestímulo é convertido em unidades relativas, denominadas coordenadas de cromaticidade. A figura 15 mostra o Diagrama CIE, com as cores distribuídas entre os três eixos de cores. O eixo das ordenadas é representado por v', enquanto que o eixo das abscissas é mostrado em u'.

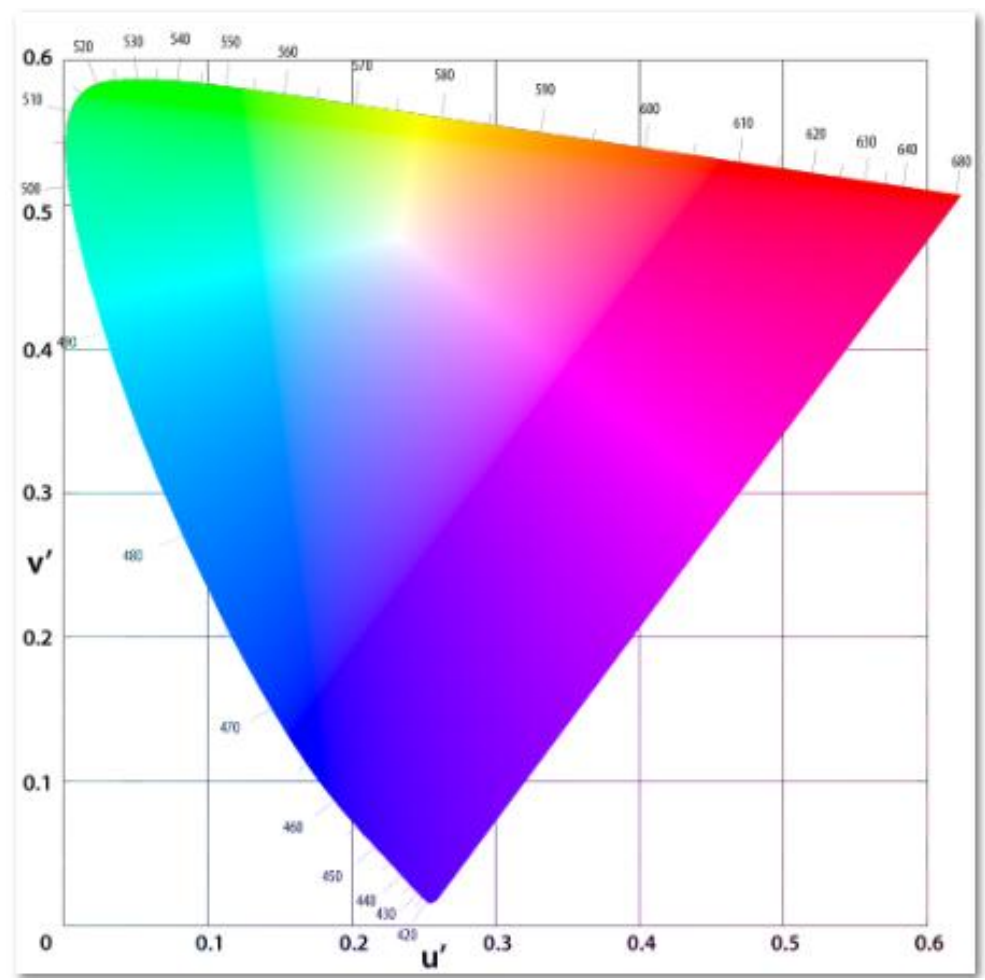

Figura 15- Representação do diagrama CIE (Commission Internationale de Ecléirage) de 1976. Notam-se as cores primárias, distribuídas nos vértices dos eixos. Fonte da imagem: www.wikipedia.com. 


\subsection{Deficiências na Visão de Cores}

Aproximadamente 4,5\% da população apresenta algum tipo de anomalia na visão de cores (POKORN, SMITH \& JONHSTON, 1979). A maior parte delas, porém, são deficiências congênitas que não apresentam ameaça à visão, bem como costumam manterse estabilizadas por toda a vida do indivíduo. No entanto, o uso de determinadas drogas, bem como certas doenças, podem afetar sobremaneira a visão de indivíduos, levando-os, de maneira progressiva, a um quadro de deficiência na visão de cores (SCHWARTZ, 2010). Em geral, as deficiências na visão de cores são divididas em duas categorias: a dicromacia e a tricromacia anômala. Na dicromacia, um dos cones responsáveis pela absorção de determinada faixa de comprimento de onda está ausente. Sendo assim, quando a deficiência ocorre em função da falta de cone L, é chamado de protanopia; já o defeito pela ausência de cones M é conhecido por deuteranopia. A tritanopia é o defeito que acomete indivíduos nos quais há a ausência de cones $\mathrm{S}$ e é uma condição mais raramente observada (RUSHTON, 1963). No caso de protanopia, os cones L são substituídos por cones M; o contrário se dá na deuteranopia (SCHWARTZ, 2010). No entanto, tal substituição não é observada na tritanopia. Já na tricromacia anômala, os três pigmentos estão presentes; no entanto, o espectro de absorção de um dos cones é deslocado de forma anormal. Assim, na tricromacia anômala denominada deuteranomalia, o espectro de absorção desloca-se para comprimentos de onda mais longos. Na protanomalia, o espectro encontra-se desviado para comprimentos de onda mais curtos. $\mathrm{Na}$ tritanomalia, são encontradas alterações nos comprimentos de onda curtos. Quanto maior o número de fotopigmentos deslocados no espectro de absorção de luz, mais grave o defeito na visão de cores.

Tais defeitos na visão de cores são classificados como deficiências de eixo protan (protanopia e protanomalia), de eixo deutan (deuteranopia e deuteranomalia) e de eixo tritan (tritanopia e tritanomalia). Indivíduos com defeitos no eixo protan possuem problemas relacionados à visão de cores mais próximas do comprimento de onda curtos (correspondentes à região do vermelho). Já indivíduos deutan encontram dificuldades para comprimentos de onda médios (cores esverdeadas) e para os tritans, a deficiência está relacionada a comprimentos de onda curtos (cores azuis e amarelas). Em geral, os indivíduos tritan possuem deficiências adquiridas. 
O desempenho na visão cromática, ou seja, a discriminação de um indivíduo entre duas cores, pode ser plotado em eixos de confusão no Diagrama CIE. Todas as cores que permanecem dentro de uma mesma linha de confusão são indistinguíveis para este indivíduo. Linhas de confusão para os tricromatas anômalos são semelhantes às encontradas para dicromatas. A Figura 16 mostra os três eixos de confusão de cores inseridos no diagrama CIE 1976. Quanto mais próximo do eixo à direita, pior a discriminação de cores para o vermelho, caracterizando-se, portanto, uma protanopia. Quanto mais próximo do eixo de confusão do verde-amarelo, pior a discriminação de cores para esta faixa do espectro, assinalando-se uma deutanopia Quanto mais abaixo, em direção ao eixo de confusão de cores do azul, pior a discriminação de cores para esta faixa de comprimento de onda, caracterizando-se como uma tritanopia.

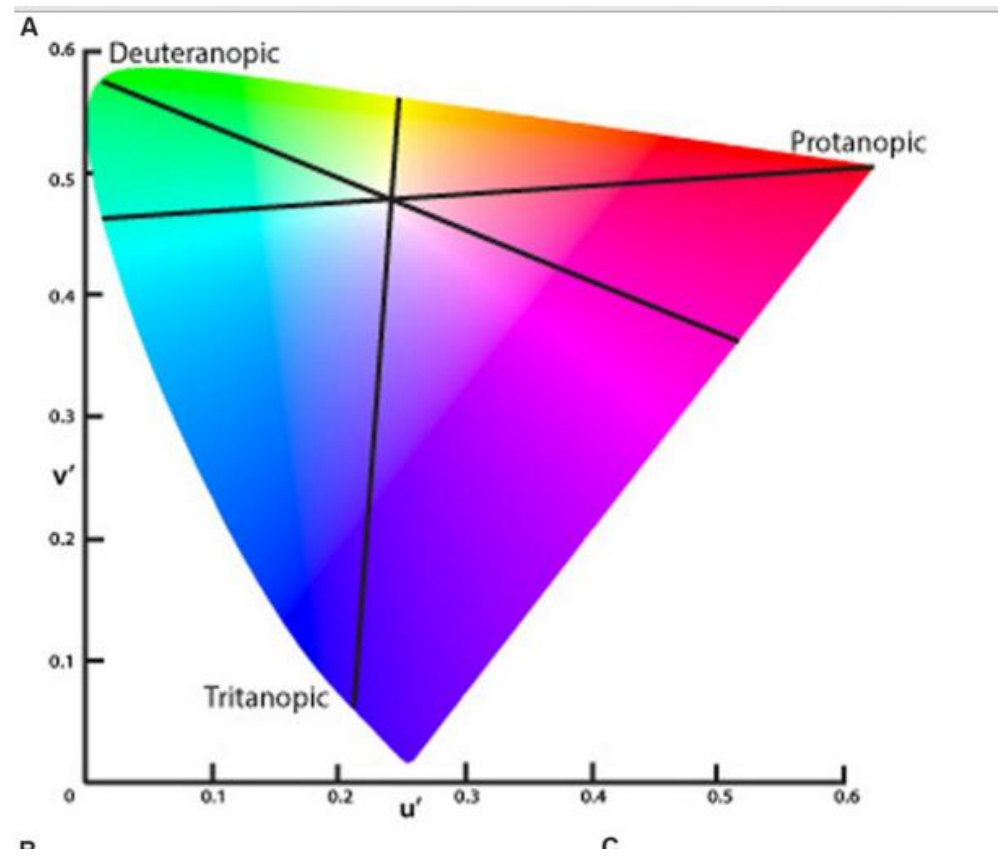

Figura 16- Os três eixos de confusão de cores do protocolo Trivector, distribuídos nas coordenadas do Diagrama CIE. Extraído de: COSTA ET AL, 2016.

No entanto, há diferenças no que se refere à lateralidade das anomalias cromáticas, em relação a defeitos congênitos ou adquiridos. Enquanto que nos primeiros indivíduos há uma simetria entre o desempenho nos diferentes testes de visão de cores, as tricromacias anômalas costumam afetar cada olho diferentemente, levando à necessidade de testagem monocular nos testes que procuram avaliar o desempenho cromático do indivíduo (SCHWARTZ, 2010). 
Além disto, há também diferenças relacionadas às diversas causas que levam à anomalia cromática. De acordo com o a regra de Köllner, alterações na retina externa resultam em deficiências no eixo tritan, enquanto que doenças na retina interna, no nervo óptico ou nas vias visuais levam a deficiências no eixo vermelho-verde (KÖLLNER, 1912, APUD: SCHWARTZ, 2010). Assim, de acordo com a regra proposta por Köllner, tendo em vista que o DM é tido como uma doença que afeta diversas células da camada mais externa da retina, alterando a bioquímica local, diabéticos podem apresentar maior índice de trinanomalia. De fato, Rockett Anderle e Bessman (1987) relataram aumento de deficiências de tipo tritan em pacientes diabéticos com mais diferentes graus de RD, comparando-os com controles. Do mesmo modo, tais pesquisadores averiguaram pior desempenho nos testes de visão de cores no eixo tritan mesmo em diabéticos sem RD, encontrando-se os piores resultados entre aqueles com RDP que se submeteram à fotocoagulação a laser. Portanto, tais dados são sugestivos de que tal deficiência esteja relacionada à própria hiperglicemia e não apenas ao quadro patológico no DM. No entanto, não é incomum que tritanopias em estágios iniciais tornem-se defeitos na visão de cores na faixa de absorção do verde-vermelho ou vice-versa (SCHWARTZ, 2010). Portanto, trabalhos que mostram deficiências na visão de cores de pacientes DM no eixo protan e/ou deutan não contrariam necessariamente o princípio de Köllner.

Deficiências adquiridas podem ser significativas, considerando-se a ocupação do indivíduo. No que se refere aos diabéticos, aparelhos que trabalham com diferenças sutis de cores para mostrar diferentes níveis glicêmicos podem oferecer uma dificuldade maior para pacientes com danos na visão de cores. Assim, mesmo que perdas discretas possam passar despercebidas mesmo para os próprios pacientes, é importante levar em consideração que deficiências na visão de cores em geral são concomitantes à DM e podem trazer pequenos prejuízos para aqueles acometidos por esta patologia. 


\subsection{Aspectos Éticos}

O presente projeto seguiu as diretrizes e normas estabelecidas na Resolução 196/96 do Conselho Nacional de Saúde que regulamentam estudos envolvendo humanos. Também foi aprovado pelos Comitês de Ética em Pesquisa com Seres Humanos do Instituto de Psicologia da Universidade de São Paulo (IPUSP), sob o número 615.954 e do Hospital das Clinicas da Faculdade de Medicina da Universidade de São Paulo (HCFMUSP) (documentos em anexo- ANEXO A).

Os procedimentos adotados na pesquisa foram esclarecidos para os participantes, assim como os possíveis riscos envolvendo a saúde deles. Foi obtido o Consentimento por escrito da pessoa ou do responsável legal do mesmo, através do Termo de Consentimento Livre e Esclarecido (TCLE) (ANEXO B), redigido conforme a Resolução CNS 466/12.

A coleta de sangue para posterior extração de DNA foi realizada por Enfermeira devidamente qualificada. Os principais riscos envolvendo punção venosa são: dor, formação de hematoma local, infecção, punção acidental de artéria e lesão de nervo próximo ao local da punção (SOCIEDADE BRASILEIRA DE PATOLOGIA CLÍNICA, 2010). No entanto, foram tomadas as devidas precauções para minimizar o risco de ocorrência de quaisquer dos incidentes descritos. As amostras de sangue não utilizadas foram propriamente descartadas.

A avaliação oftalmológica foi inteiramente realizada por médicos oftalmologistas colaboradores deste projeto ou obtida através de prontuário do paciente no Sistema de Informação e Gestão Hospitalar (SIGH) do HCFMUSP, mediante consentimento do próprio paciente e do médico endocrinologista responsável. A avaliação psicofísica foi realizada pela própria pesquisadora e para alguns dados, por colaboradores do projeto, todos devidamente treinados e qualificados.

\subsection{Participantes}

Desenho do Estudo: Para o presente estudo, utilizou-se dados de pacientes que apresentavam tanto o tipo 1 quanto o tipo 2 da doença. Tal escolha deve-se ao fato que a $\mathrm{RD}$ acomete ambos os tipos da doença. A única diferença reside no fato de que o 
diagnóstico de RD em diabéticos tipo 1 ocorre predominante após 5 anos de diagnóstico de DM, sendo que apenas em $8 \%$ dos casos o paciente apresentará alguma manifestação clínica da doença antes deste período (DRAZNIM ET AL, 2011). No entanto, as alterações visuais investigadas através dos testes psicofísicos utilizados neste estudo surgem bem antes das manifestações clínicas da doença e, portanto, o tempo de diagnóstico também não se tornou um critério decisivo de exclusão do estudo.

Com relação à idade dos participantes do estudo, as primeiras manifestações de RD estão relacionadas com o tempo de DM, sendo que após 20 anos de doença, mais de $90 \%$ dos diabéticos tipo 1 e $60 \%$ dos tipo 2 apresentarão algum grau de dano ocular (SOCIEDADE BRASILEIRA DE DIABETES, 2015). Porém, as alterações investigadas ocorrem incipientemente às manifestações clínicas da doença, sendo, portanto, possível encontrá-las nas mais precoces faixas etárias.

A respeito dos pacientes com manifestações clínicas de RD, optou-se por excluir da amostra aqueles com RD proliferativa, já que os danos causados tanto pela doença quanto por tratamentos anteriores por fotocoagulação a laser prejudicariam a obtenção dos dados referentes à avaliação visual. Da mesma forma, pessoas com glaucoma ou catarata (em qualquer grau da doença) ou quaisquer outras doenças (oftalmológicas ou não) que pudessem atrapalhar a obtenção de resultados confiáveis foram excluídas do estudo.

Para algumas análises mais detalhadas, tais como aquelas que buscaram relacionar a visão de cores e o genótipo com diversos aspectos do DM (presença de RD, tempo de diagnóstico de DM, tipo de DM e Glicemia) ou com antecedentes familiares do DM em controles, foram utilizados os resultados do protocolo mais simples do teste utilizado. Tal escolha se deveu pelo fato da versão Trivector do teste de visão de cores apresentar variáveis em números naturais, facilitando assim a manipulação e a apresentação dos dados. Também não foram encontradas discrepâncias entre os resultados de cada participante para cada uma das versões utilizadas. De fato, o próprio manual do teste cita o Trivector como um instrumento confiável para mapeamento da visão de cores (MOLLON, REFFIN, 2000; VENTURA， SILVEIRA， RODRIGUES， SOUZA, GUALTIERI, BONCI \& COSTA, 2003). 
Características da Amostra e Tamanho Amostral: O estudo foi multicêntrico e a amostra definida por conveniência. Foram recrutados participantes de um Centro de estudo de importância nacional, o que contribuiu para que a amostra fosse o mais heterogênea possível. O tamanho amostral foi definido a partir dos dados quantitativos, levando-se em consideração um intervalo de confiança de 95\% ( $\alpha$ de 0,05 e Z $\alpha^{1 / 2}$ de 1,96), através da fórmula:

$$
\mathrm{N}=\left[\left(\mathrm{Z} \alpha^{1 / 2} \cdot \sigma\right) / \mathrm{E}\right]^{2}
$$

sendo $\mathrm{N}$, o tamanho amostral, $\sigma$, o desvio padrão e $\mathrm{E}, \mathrm{o}$ erro máximo padrão. Para a variável idade, o $\mathrm{N}$ mínimo calculado através da fórmula foi de 44 participantes $(43,89)$. No entanto, esta variável foi apenas uma das que foram analisadas, e por isto, a amostra precisou ser aumentada para que resultados significativos pudessem ser obtidos. No entanto, a fim de evitar o superdimensionamento amostral, o que poderia reduzir os intervalos de confiança e permitir diferenças clinicamente não relevantes entre os subgrupos (MIOT, 2011), os resultados no teste de visão de cores não foram considerados nos cálculos de tamanho amostral. Os resultados no CCT possuem uma grande amplitude, o que dificultaria a obtenção de valores aplicáveis no cálculo do N.

\subsubsection{Grupo Diabéticos}

Dados Demográficos: Participaram do estudo 95 diabéticos, de ambos os sexos (49 mulheres e 46 homens) e com idades entre 16 e 87 anos (média= 48,33 anos; desvio padrão $=16,9)$. Os dados brutos referentes a cada participante encontram-se em anexo (ANEXO C).

Critérios de Inclusão: Foram incluídos no grupo experimental de participantes de ambos os sexos, a partir de 16 anos de idade, de qualquer nível escolar, desde que atendessem os seguintes critérios:

- Diagnóstico de DM tipo 1 ou DM tipo 2, estabelecido segundo critérios diagnósticos da Organização Mundial de Saúde;

- Acuidade Visual mínima de 20/40 ( $\log$ MAR 0,3) com correção;

- Consentimento na participação na pesquisa, pelo próprio sujeito, bem como pelo seu responsável legal (se cabível). 
Critérios de Exclusão: Foram excluídos da amostra participantes que apresentassem pelo menos uma das condições listadas abaixo:

- Presença de patologia que prejudicasse o entendimento ou a execução do teste (Ex: retardo mental moderado, sequelas graves de Acidentes Vasculares Encefálicos (AVEs), surdez);

- Opacidade dos meios ópticos, catarata ou glaucoma;

- Daltonismo;

- Contato prolongado com produtos químicos e/ou solventes, com vapor de mercúrio ou com metais pesados;

- Uso prolongado de cloroquina.

Recrutamento dos Participantes: Os participantes foram recrutados principalmente através de duas formas. Foram convidados a participar, mediante contato telefônico, pacientes de estudos anteriores realizados no Laboratório da Visão do IPUSP, cujos dados estavam arquivados no Banco de Dados da referida Instituição. Além disto, a maioria dos participantes foi recrutada através da Liga de Controle do Diabetes do Hospital das Clinicas da Faculdade de Medicina da Universidade de São Paulo (HCFMUSP), mediante contato telefônico ou pela abordagem direta do paciente em dia de consulta. Tais estratégias mostraram-se extremamente satisfatórias, já que os pacientes puderam ser préselecionados através de dados coletados em pesquisa ou em consultas clínicas, o que garante poucas perdas por exclusão posterior.

Diabéticos que se interessaram em participar, mas que não estavam incluídos em uma das formas de recrutamento descritas acima foram incluídos na amostra, desde que fossem avaliados por médicos e/ou enfermeiros colaboradores do estudo.

\subsubsection{Grupo Controle}

Dados Demográficos: Participaram do estudo 114 controles, de ambos os sexos (73 mulheres e 41 homens), com idades entre 17 e 69 anos (média= 38,38 anos; desvio padrão= 12,81). Em anexo (ANEXO D), encontram-se os dados brutos referentes a cada participante. A maior proporção de mulheres no grupo controle, comparado ao de 
diabéticos, não foi considerada relevante, já que os aspectos estudados não são gênero dependentes.

Critérios de Inclusão: Foram elegíveis para o grupo controle pessoas de ambos os sexos, a partir de 16 anos de idade, de qualquer nível escolar, que obedecessem aos seguintes critérios:

- Acuidade Visual mínima de 20/40 (logMAR 0,3) com correção;

- Consentimento na participação na pesquisa, pelo próprio sujeito, bem como pelo seu responsável legal (se cabível).

Critérios de Exclusão: Os participantes que apresentassem uma ou mais das condições listadas abaixo foram excluídos do grupo controle.

- Diagnóstico de DM tipo 1 ou DM tipo 2, estabelecido segundo critérios diagnósticos da Organização Mundial de Saúde;

- Presença de patologia que prejudicasse o entendimento ou a execução do teste (Ex: retardo mental moderado, sequelas graves de Acidentes Vasculares Encefálicos (AVEs), surdez);

- Opacidade dos meios ópticos, catarata ou glaucoma;

- Daltonismo;

- Contato prolongado com produtos químicos e/ou solventes, com vapor de mercúrio ou com metais pesados;

- Uso prolongado de cloroquina.

Recrutamento dos Participantes: Os participantes controles foram recrutados de diversas maneiras. Convidaram-se, mediante contato telefônico, pessoas que já haviam tomado parte de estudos anteriores no Laboratório da Visão do IPUSP. Também foi utilizada a estratégia "bola de neve", nos quais parentes e conhecidos da pesquisadora foram convidados pessoalmente a participar do estudo, bem como a divulgá-lo, por sua vez, a parentes e conhecidos.

Outra estratégia utilizada consistiu na afixação de cartazes nos edifícios do Instituto de Psicologia da Universidade de São Paulo e no Sindicato dos Trabalhadores da Universidade de São Paulo (SINTUSP), bem como na divulgação da pesquisa através das 
redes sociais. Os contatos da pesquisadora foram disponibilizados e caso houvesse interesse, o participante entraria em contato.

Apesar de tais táticas terem garantido um grande número de interessados, já que atingiu ou pessoas ligadas à pesquisadora ou que frequentavam as proximidades do local de coleta de dados (o que facilitaria a participação), muitos sujeitos foram excluídos posteriormente. Alguns foram diagnosticados com doenças oftalmológicas no decorrer da avaliação e foram orientados quanto às medidas a serem tomadas e encaminhados para tratamento.

\subsection{Procedimentos Experimentais}

\subsubsection{Anamnese e Avaliação Oftalmológica}

Os participantes foram submetidos à Avaliação Oftalmológica, a fim de detectar possíveis doenças oftalmológicas que pudessem prejudicar a obtenção dos dados. Os pacientes que realizam tratamento na Liga de Controle do Diabetes, do HCFMUSP e que participaram deste estudo, não foram submetidos a tal avaliação, já que esses dados estavam disponíveis e atualizados em prontuários eletrônicos.

Para o grupo controle, a avaliação possuiu um caráter mais rigoroso para aqueles com mais de 30 anos, já que doenças oftalmológicas consideradas como critérios de exclusão são mais comuns nesta faixa etária. Assim, para estes participantes, a ausência de um ou mais dos exames descritos levaram à exclusão da pessoa da amostra analisada. Os exames realizados foram: verificação da acuidade visual (AV) (com e sem correção), biomicroscopia e fundoscopia com lâmpada de fenda (para avaliação das estruturas do segmento anterior, do nervo óptico e da retina central) e refração. Observou-se um período de, no máximo, seis meses entre a avaliação oftalmológica e o teste de visão de cores.

Da mesma forma, todos os diabéticos foram oftalmologicamente avaliados. Foram realizados os mesmos exames que nos controles. Para os pacientes atendidos na Liga de Controle do Diabetes, os dados averiguados eram referentes aos mesmos exames realizados para todos os outros participantes. 
Todos os participantes foram submetidos a uma anamnese sobre o seu estado geral de saúde. A anamnese incluiu dados sobre hábitos (etilismo, tabagismo, consumo de drogas recreacionais), histórico pessoal de DM, de hipertensão arterial sistêmica, de doenças oftalmológicas, reumatológicas e neurológicas, histórico familiar de doenças, traumatismos cranianos e/ou tratamentos neurológicos e contato anterior com produtos químicos (instrumento em ANEXO E). Este instrumento permitiu avaliar as condições do indivíduo de atender aos critérios de elegibilidade para o estudo, bem como obter dados sobre possíveis influências no desempenho do sujeito nos testes psicofísicos.

\subsubsection{Avaliação Psicofísica}

Equipamento Utilizado: O Cambridge Colour Test (CCT) é um instrumento computadorizado para a determinação do limiar de discriminação de cores, utilizado para avaliação da visão de cores. O teste é uma combinação do Princípio de Chilbret (1877), que quantifica a variação da diferença cromática entre a figura e o fundo através de diferentes direções no espaço cromático e de Stilling (1877), que defende a variação de tamanho e de luminância entre a figura e fundo para evitar ruído (HASROD, RUBIN, 2015). Assim, o CCT consiste na apresentação sucessiva de placas pseudo-isocromáticas, contendo como estímulo um "C" de Landolt, que difere do fundo em termos de cromaticidade. O estímulo e o fundo são formados por pequenos círculos de tamanhos variados, com valores de luminância variando entre 7 e $15 \mathrm{~cd} . \mathrm{m}^{2}$, cuja distribuição se dá de maneira aleatória, seguindo princípios de ruído de forma e luminância Os estímulos possuem $5,4^{\circ}$ de diâmetro interno e a abertura possui $1,25^{\circ}$ de abertura, equivalente a $1^{\circ}$ de ângulo visual (Figura 17). 


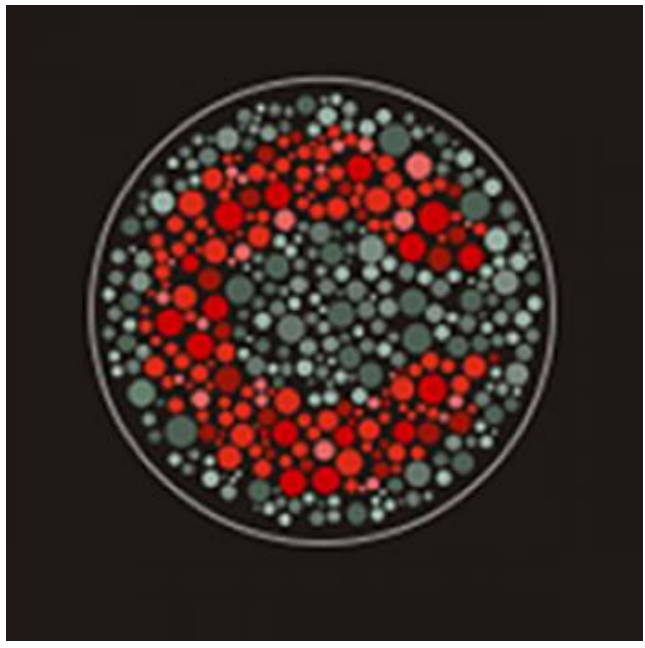

Figura 17- Exemplo de Estímulo empregado no CCT. Neste caso, a abertura do "C" encontra-se voltada para a direita e o vermelho encontra-se na saturação máxima.

$\mathrm{O}$ "C" é apresentado na tela com sua abertura aleatoriamente voltada para uma de quatro direções distintas (superior, inferior, direita e esquerda), durante 03 segundos. A tarefa do sujeito é indicar a direção na qual a abertura da letra pressionando um dos quatro botões em uma caixa de resposta (CT- Cambridge Research Instruments, Rochester, UK). O participante não é capaz de predizer o estímulo a não ser pela percepção de cromaticidade, já que sugestões de contorno e de luminância não estão disponíveis.

No início do teste, a cor do "C" de Landolt é apresentada com máxima saturação. Então, ajustando dinamicamente as diferenças de cromaticidade entre a figura e o fundo, segundo a performance do sujeito (método psicofísico das escadas), obtêm-se uma medida exata para aquele participante.

Na versão mais básica do teste, denominada "Trivector", a figura diferencia-se do fundo ao longo de três eixos de confusão dentro do espaço de cores, correspondentes à sensibilidade a ondas de comprimento longo (eixo protan), médio (eixo deutan) e curto (eixo tritan). Já na versão mais longa do teste, são geradas elipses de discriminação de MacAdam, através de vetores distribuídos em coordenadas específicas no diagrama CIE. Dados normativos foram avaliados em pesquisa multicêntrica, que apontou a confiabilidade das medidas adquiridas através do CCT (VENTURA ET AL, 2003; HASROD, RUBIN, 2015). Com relação à interpretação dos resultados, o manual do teste sugere adotar como pontos de corte os seguintes resultados para o Trivector: < 100 para o eixo protan, $<100$ para o eixo deutan e $<150$ para o eixo tritan (MOLLON, REFFIN, 
2000). Ou seja, quanto menor o resultado, melhor a discriminação de cores do sujeito. Já para a Elipse, quanto menor a elipse formada, melhor a discriminação, sendo que o manual sugere que o raio do eixo maior não deve ultrapassar 2,0 unidades (MOLLON, REFFIN, 2000).

Para a presente pesquisa, foi utilizada a versão 2.0 do Cambridge Colour Test (CRS ${ }^{\mathrm{TM}}$, Kent, UK), instalada em microcomputador Dell ((Dell Dimension XTC-T600), com placa gráfica instalada VSG 2/5, resolução de 15 bits (Cambridge Research Instruments, Rochester, $U K$ ). Os estímulos foram apresentados em monitores coloridos de 21', com resolução de 800X600 pixels (Sony FD Triniton, Modelo GDM-F500T9 e Sony G420 Triniton, Multiscan).

\subsubsection{Sequenciamento Genético}

Aquisição de Dados: Todos os participantes foram submetidos à avaliação de sua capacidade de discriminação cromática através do CCT. Antes da execução do teste, a acuidade visual (com correção) dos participantes foi mensurada, mesmo para aqueles que já haviam realizado a avaliação oftalmológica. Como há uma variação significativa dos valores da AV entre diabéticos, optou-se por medi-la no momento imediatamente anterior ao teste.

Os sujeitos realizaram o teste individualmente nas instalações do Laboratório da Visão, no Centro Escola do Instituto de Psicologia da Universidade de São Paulo (CEIPIPUSP). O teste aconteceu em uma sala totalmente escura e os participantes sentaram-se a uma distância de 2,92 $\mathrm{m}$ de distância da tela. Nesta distância, a abertura do "C" corresponde a $1^{\circ}$ de ângulo visual. $\mathrm{O}$ teste foi realizado monocularmente.

A escolha do olho examinado ocorreu de forma aleatória, exceto quando havia alguma restrição em um dos olhos, tais como doenças oculares. Foram aplicadas ambas as versões do teste, sendo que para o protocolo da Elipse, foi utilizada apenas a elipse central (gerada em torno da mesma cromaticidade de fundo do Trivector). Primeiramente, aplicouse a versão Trivector e, em seguida a Elipse. Os resultados foram salvos em imagens, para posterior análise. 
Extração de Material Genético: Foram coletadas, para cada participante, duas amostras de sangue ( $3 \mathrm{~mL}$ cada), através de punção venosa. As mesmas foram armazenadas em tubos contendo citrato de sódio $\left(\mathrm{Na}_{3} \mathrm{C}_{6} \mathrm{H}_{5} \mathrm{O}_{7}\right)$ 0,2\% e mantidas sob refrigeração por, no máximo, 5 dias, até o início da extração de DNA. A extração de material genético foi realizada para cada uma das amostras colhidas.

Para a extração de material genético, utilizou-se o Kit Gentra Puregene® DNA Blood Kit (Gentra Systems), empregando o protocolo de extração através de amostra completa de sangue (Whole Blood), descrito no Manual do Fabricante (Gentra ${ }^{\circledR}$ Puregene ${ }^{\circledR}$ Handbook-Applied Biosystems, disponível em: www.qiagen.com). A extração foi realizada a partir de duas amostras de sangue para cada participante.

Após a devida extração do material genético, as amostras foram quantificadas (em termos de quantidade de ácido nucléico e presença de contaminação) em espectrofotômetro de massa (Nano Drop 2000c, Thermo Scientific). Em seguida, foram armazenadas em tubos de $1,5 \mathrm{~mL}$ e mantidas congeladas $\left(-18^{\circ} \mathrm{C}\right)$ até serem utilizadas.

Amplificação de DNA por PCR (Polymerase Chain Reaction) - A fim de preparar o material para posterior sequenciamento, a amplificação dos segmentos dos genes estudados foi realizada através da técnica de PCR. Para o presente estudo, foram avaliados três SNPs (Single Nucleotide Polymorphisms) no gene EPO: rs1617640, rs507392 e rs551238. Para cada um dos SNPs, foi realizada uma PCR, obedecendo a protocolos previamente estabelecidos (TONG ET AL, 2008).

Para tanto, utilizou-se um dos seguintes kits para PCR: TaqMan ${ }^{\circledR}$ PCR Core Reagents ${ }^{\circledR}$ Kit, Platinum Taq ${ }^{\circledR}$ DNA Polymerase (Invitrogen, USA) ou AmpliTaq Gold® DNA Polymerase ${ }^{\circledR}$ Kit (Applied Biosystems). Adicionou-se a um microtubo de 0.2mL: 37,75 $\mu \mathrm{L}$ de água bidestilada (Mili-Q), $5 \mu \mathrm{L}$ de $10 \mathrm{X}$ (ou $3 \mathrm{X}$ ) buffer, $1 \mu \mathrm{L}$ de deoxinucleotídeos trifosfatos $(d N T P s), 1,5 \mu \mathrm{L}$ de cada primer (um para a sequência senso $(F w)$, outro para a sequência reversa (Rv)), $2 \mu \mathrm{L}$ de $\mathrm{MgCl}_{2}$ ou de $\mathrm{Mg}(\mathrm{AC}) \mathrm{Cl}_{2}, 0,25 \mu \mathrm{L}$ de enzima (AmpliTaq Gold, Taq Platinum ou Taq Recombinante) e $1 \mu \mathrm{L}$ de amostra. As reações foram realizadas no termociclador Veriti 96 Well Thermal Cycler, da Applied Biosystems.

As sequências de nucleotídeos dos primers utilizados, o tamanho dos fragmentos gerados pela PCR, bem como as condições para a reação para cada um deles encontram-se na Tabela 1. 
Tabela 1-Descrição dos primers utilizados e condições para a realização da PCR, para cada um dos polimorfismos pesquisados.

\begin{tabular}{|c|c|c|c|c|}
\hline SNP & $\begin{array}{l}\text { Identificaçãc } \\
\text { do primer }\end{array}$ & $\begin{array}{l}\text { Sequência de nucleotídeos do } \\
\text { primer }\end{array}$ & $\begin{array}{l}\text { Tamanho do } \\
\text { Amplicon }\end{array}$ & Condições para PCR \\
\hline rs1617640 & EPO 16 & $\begin{array}{l}\text { Fw: 5'GTCCATTGTGCAGGACACACA3' } \\
\text { Rv: 5'AACTCCTGGGCTCAAAGGAT3' }\end{array}$ & $369 \mathrm{pb}$ & $\begin{array}{l}-95^{\circ} \mathrm{C}: 9 \mathrm{~min} ; \\
-94^{\circ} \mathrm{C}: 15 \mathrm{~s}: \\
-\mathrm{TA} \rightarrow 60^{\circ}: 15 \mathrm{~s}(35 \mathrm{X}) \\
-72^{\circ}: 30 \mathrm{~s} ; \\
-72^{\circ}: 7 \mathrm{~min} ;\end{array}$ \\
\hline rs507392 & EPO 50 & $\begin{array}{l}\text { Fw: 5'TCACTGTCCCAGACACCAAA3' } \\
R v: \text { 5'AGCTCACTGCAGCCTCAAAT3' }\end{array}$ & $425 \mathrm{pb}$ & $\begin{array}{l}-95^{\circ} \mathrm{C}: 9 \mathrm{~min} ; \\
-94^{\circ} \mathrm{C}: 15 \mathrm{~s}: \\
-\mathrm{TA} \rightarrow 62^{\circ} \quad(35 \mathrm{X}): 15 \mathrm{~s} ; \\
-72^{\circ}: 30 \mathrm{~s} ; \\
-72^{\circ}: 7 \mathrm{~min} ;\end{array}$ \\
\hline rs551238 & EPO 55 & $\begin{array}{l}\text { Fw: 5'CCTGTTTTCGCACCTACCAT3' } \\
\text { Rv: 5'TAGCGAGGATGTGCATTGG3' }\end{array}$ & $585 \mathrm{pb}$ & $\begin{array}{l}94^{\circ} \mathrm{C}: 1 \mathrm{~min} ; \\
-94^{\circ} \mathrm{C}: 15 \mathrm{~s}: \\
-\mathrm{TA} \rightarrow 60^{\circ}(37 \mathrm{X}): 30 \mathrm{~s} ; \\
-72^{\circ}: 30 \mathrm{~s} ; \\
-72^{\circ}: 7 \mathrm{~min} ;\end{array}$ \\
\hline
\end{tabular}

SNP: Single Nucleotide Polymorphisms; PCR: Polymerase Chain Reaction; Fw: Forward; Rv: Reverse; pb: pares de base; TA: temperatura de anelamento do primer ao DNA para a sequência a ser amplificada.

Eletroforese em Gel de Agarose: Após a reação descrita no item anterior, os produtos obtidos na PCR foram submetidos à eletroforese em gel de agarose 10\%, com o intuito de averiguar o sucesso do procedimento prévio. Uma amostra de cada um dos produtos amplificados e um marcador de peso molecular (100 bp DNA Ladder ${ }^{\circledR}$, Invitrogen, CA, USA) foram corados com Blue/Red Dye, para permitir posterior visualização. O corante Blue/Red Dye foi obtido através da mistura de 10X Blue Juice-Gel Loading Buffer ®com Gel Red Loading Buffer®, ambos da Invitrogen (CA, USA) e de água bidestilada (Mili-Q).

O gel de agarose foi mergulhado em uma cuba de eletroforese contendo tampão de corrida TAE 1X, obtido através da diluição do tampão TAE 50X. O TAE 50X é uma mistura de TRIS Base, Ácido Acético Glacial e EDTA 0,5 M. A cuba então foi conectada a eletrodos para permitir a corrida das amostras. 
Os produtos amplificados formam uma banda específica, visível sob lâmpada de radiação ultravioleta (UV), correspondente à posição no gel do fragmento contendo a sequência amplificada. Este procedimento possibilita, portanto, saber se o fragmento foi propriamente amplificado. Foi obtida então uma fotografia do gel de agarose contendo as amostras coradas, para posterior consulta (Figura 18).

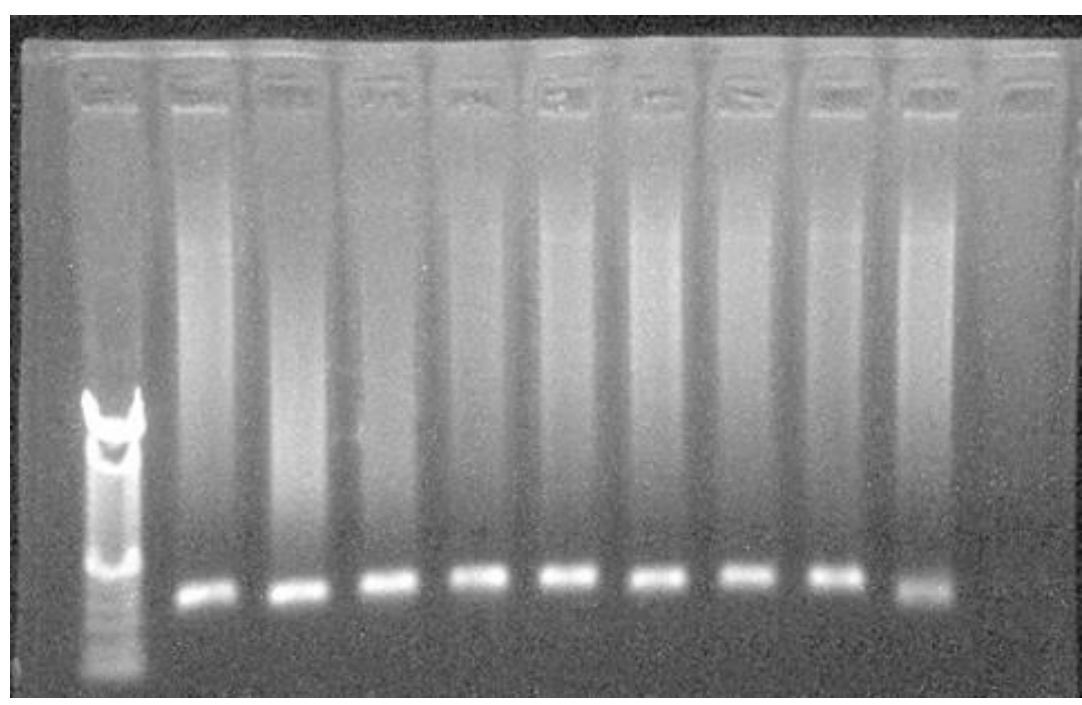

Figura 18 - Gel de agarose $10 \%$, fotografado sob iluminação ultravioleta. As amostras amplificadas aparecem como bandas específicas. À esquerda encontra-se o marcador de peso molecular, amplificado a cada 100 pares de base.

Purificação das Amostras: Os produtos de PCR contendo os fragmentos devidamente amplificados foram devidamente purificados, a fim de garantir a pureza do fragmento de DNA a ser sequenciado. A purificação foi feita utilizando-se um dos seguintes kits: Illustra ${ }^{\mathrm{TM}}$ GFX ${ }^{\mathrm{TM}}$ PCR DNA ou Gel Band Purification Kit (GE Healthcare). As amostras foram então acondicionadas em tubos de 1,5 mL e mantidas à temperatura de $18^{\circ} \mathrm{C}$ até o sequenciamento.

Os procedimentos para extração de DNA, PCR e purificação foram inteiramente realizados no laboratório de genética do Laboratório da Visão do Instituto de Psicologia da Universidade de São Paulo (LABVIS-IPUSP).

Sequenciamento Genético: Para a realização do sequenciamento, é necessária uma segunda PCR, seguindo protocolo previamente estabelecido. Nesta reação, foi utilizado o kit DYEnamic ET Dye Terminator ${ }^{\circledR}$ (MegaBACETM, GE Healthcare). Foram adicionados a um microtubo de $0,2 \mathrm{~mL}$ os seguintes materiais: $4,2 \mu \mathrm{L}$ de água bidestilada (Mili-Q), $1 \mu \mathrm{L}$ de Big Dye, 1,5 $\mu \mathrm{L}$ de $5 X$ Big Dye Buffer, $0,8 \mu \mathrm{L}$ de primer (sequência $F w)$ e $2,5 \mu \mathrm{L}$ do produto de PCR purificado. A reação de PCR foi realizada sob as 
seguintes condições: 1 minuto a $96^{\circ} \mathrm{C}, 10$ segundos a $96^{\circ} \mathrm{C}$, temperatura de anelamento: $50^{\circ}$ C por 5 segundos (40 ciclos) e $60^{\circ} \mathrm{C}$ por 2 minutos.

A purificação desta PCR foi realizada utilizando-se os seguintes reagentes: SAM Reagent ${ }^{\circledR}$ e Xterminator Solution ${ }^{\circledR}($ PreMIX-GE Healthcare). O sequenciamento seguiu a esta etapa e foi realizado em Sequenciador de Modelo 3500 xL Genetic Analyzer, da Applied Biosystems/Hitachi. O resultado do sequenciamento foi então gravado em CD para posterior análise.

As etapas aqui descritas foram realizadas inteiramente no Instituto de Ensino e Pesquisa (IIEP) do Hospital Israelita Albert Einstein.

Análise das Sequências: A análise foi realizada através do Programa BioEdit (disponível para download no sítio: http://www.mbio.ncsu.edu/bioedit/bioedit.html). O arquivo foi aberto e identificou-se o polimorfismo procurado, utilizando-se para tanto a sequência de nucleotídeos anterior e posterior ao SNP procurado. A série de nucleotídeos utilizada para a localização de cada um dos SNPs, bem como os alelos procurados, encontra-se descritos na Tabela 2.

Tabela 2- Sequência de nucleotídeos utilizada para localização do SNP procurado e o alelo alvo.

\begin{tabular}{lll}
\hline $\begin{array}{l}\text { Identificação do } \\
\text { SNP }\end{array}$ & Sequência de nucleotídeos utilizada & Alelo Alvo \\
\hline EPO 16 & Fw: CCCTGAGCCAGA*GAGTG & T ou G \\
& $R v:$ CACTC*TCTGGCTCAGGG & A ou C \\
\hline EPO 50 & Fw: GGTGA*GTGGTGTGTGGTGG & T ou C \\
& $R v:$ TACCACCATGCACCAC*TCACC & A ou G \\
\hline EPO 55 & Fw: AATGGAG*CACCTTATTGA & A ou C \\
& $R v:$ TCAATAAGGTG*CTCCATT & T ou G \\
\hline
\end{tabular}

SNP: Single Nucleotide Polymorphisms; Fw: Forward; Rv: Reverse; *: alelo procurado

Os haplótipos possíveis dos SNPs investigados (rs1617640, rs507392 e rs551238) são, portanto, TTA ou GCC para homozigotos e TTA/GCC para heterozigotos. Assim, com 
a identificação dos nucleotídeos de cada um dos SNPs construiu-se uma tabela em Excel contendo o haplótipo de cada participante da pesquisa.

\subsection{Análise Estatística}

Os resultados obtidos estão apresentados em termos de média e desvio padrão. Os resultados foram apresentados em termos de idade, gênero, tipo de DM, glicemia, acuidade visual com correção, tempo de diagnóstico do DM e diagnóstico de RD para o grupo dos casos e idade, gênero, acuidade visual com correção e antecedentes familiares para os Controles.

A análise estatística foi feita com uso do programa SPSS versão 15.0 (Chicago, Illinois). Os resultados foram considerados significantes para $\mathrm{p}<0,05$. As variáveis contínuas foram testadas pelo teste de Shapiro-Wilk, para detectar distribuição normal. Para os parâmetros genéticos, foram utilizados o teste-T nas amostras independentes e o de Mann-Whitney e Kruskal-Wallis para as variáveis dependentes. Assim, foram avaliadas, separadamente, possíveis correlações entre o haplótipo e o tipo de DM, a taxa glicêmica, a presença de RD e os resultados no Protocolo Trivector do CCT. Da mesma forma, procedeu-se a avaliação entre os antecedentes familiares de DM e os resultados obtidos para cada genótipo para os participantes controles.

Os testes não paramétricos (distribuição livre) são os mais adequados quando não se conhece a distribuição de dados em uma dada população, quando a distribuição é assimétrica e a transformação de dados não é indicada ou quando os dados convergem para uma gaussiana para determinados valores e mostram-se assimétricos para outros. O teste de Kruskal-Wallis é utilizado quando há mais de dois grupos a serem comparados e o de Mann-Whitney é indicado para comparação de duas amostras independentes.

As associações entre os resultados no Teste Trivector com o tempo de doença, com o tipo de DM e com a taxa glicêmica foram feitas através do teste de Mann-Whitney. As demais variáveis foram avaliadas pelo teste de Kruskal-Wallis. Além disto, diversos parâmetros (Tipo de doença X presença de RD; tempo de DM X RD e Glicemia X RD) foram comparados através do teste do qui-quadrado $\left(\chi^{2}\right)$, utilizado para averiguar a associação entre duas varáveis qualitativas. Os polimorfismos estudados foram submetidos ao teste de probabilidade de aderência ao Equilíbrio de Hardy-Weinberg (EHW), também 
através do $\chi^{2}$, visando averiguar a distribuição dos dados e compará-la a um valor esperado em uma dada população.

Já com relação ao protocolo das Elipses, foram utilizadas as médias dos grupos DM e Controles, para gerar uma elipse de discriminação que mostrasse o desempenho de cada grupo. Também se calculou as elipses de discriminação do grupo DM, com relação a cada um dos haplótipos. Tais resultados foram também expressos em termos de comprimento, de semieixos, de ângulo e de área. No entanto, para a análise estatística utilizaram-se os resultados do protocolo Trivector, já que este fornece resultados em variáveis discretas, sendo, portanto, mais fáceis de manipular e mais confiáveis em análises que envolvem comparações.

Em trabalho de Hosseini e colegas (2014), o SNP rs1617640 não foi associado com a progressão da $\mathrm{RD}$, resultado que vai de encontro àqueles encontrados em outras pesquisas. Para explicar tal discrepância, os autores colocam que os estudos prévios realizados geralmente não levam em consideração fatores conhecidos de risco para RD (tais como duração da doença ou controle glicêmico). Em decorrência disto, escolhemos relacionar tais dados com o haplótipo e não meramente entre si. 
7. RESULTADOS 


\subsection{Participantes}

As características referentes aos participantes diabéticos (idade, gênero, tipo de DM, glicemia, acuidade visual com correção, tempo de diagnóstico do DM e diagnóstico de RD) estão apresentados na Tabela 3. Os dados brutos obtidos para cada participante diabético encontram-se em anexo (ANEXO C).

Tabela 3- Características dos diabéticos participantes do estudo (Idade, Gênero, Tipo de Diabetes, Glicemia, Acuidade Visual, Tempo de Diagnóstico e Presença de RD).

\begin{tabular}{|c|c|c|}
\hline \multicolumn{3}{|l|}{ Idade (anos) } \\
\hline \multicolumn{3}{|l|}{ Menor valor: 16 anos; } \\
\hline Maior valor: 87 anos; & Média: 48,33 & DP: 16,90 \\
\hline Gênero, n (\%) & Mulheres: 49 (52\%) & Homens: 46 (48\%) \\
\hline Tipo de Diabetes, n (\%) & Tipo 1: 31 (33\%) & Tipo 2: 64 (66\%) \\
\hline \multicolumn{3}{|l|}{ Glicemia (mg/dL) } \\
\hline \multicolumn{3}{|l|}{ Menor valor: $60 \mathrm{mg} / \mathrm{dL}$} \\
\hline Maior valor: $442 \mathrm{mg} / \mathrm{dL}$ & Média: 164,23 & DP: 70 \\
\hline AVcc (em logMAR) & Pior resultado: 0,3 & Melhor resultado: -0.3 \\
\hline \multicolumn{3}{|l|}{ TD (em anos) } \\
\hline \multicolumn{3}{|l|}{ Menor valor: 1 mês } \\
\hline Maior valor: 44 anos & Média: 14,04 & DP: 9,01 \\
\hline$R D, n(\%)$ & RDNP: 12 (13\%) & Sem RD: 83 (87\%) \\
\hline Olho Testado, $n$ (\%) & OD: 49 (52\%) & OE: $46(48 \%)$ \\
\hline
\end{tabular}

Com relação à população aqui estudada, entre os diabéticos com RD o tempo de diagnóstico de DM variou entre 2,5 e 35 anos (média= 18,81 anos; desvio padrão=8,14). Já no grupo sem RD, o tempo de diagnóstico esteve entre um mês e 44 anos (média=12,91 anos; desvio padrão= 8,96) (Gráfico 1). O tempo de diagnóstico de DM é uma influência significativa para o desenvolvimento da $\mathrm{RD}(\mathrm{p}=0,035)$. $\mathrm{O}$ tempo de diagnóstico é um dos fatores de conhecida influência no desenvolvimento da RD. 


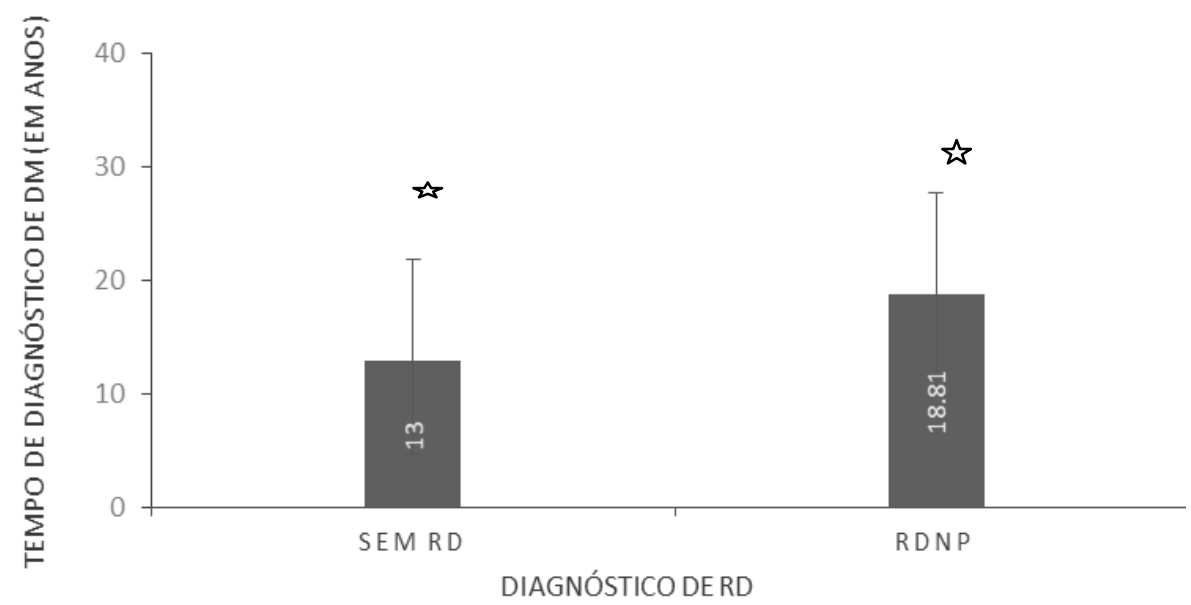

Gráfico 1- Diagnóstico de retinopatia diabética em função do tempo de diagnóstico de diabetes (em anos). As linhas representam o desvio padrão da média. Legenda: RDNP: Retinopatia diabética não proliferativa. A indica significância.

Quanto ao tipo de DM em relação ao diagnóstico de RD, dos 31 diabéticos tipo 1, três apresentavam RDNP (10\%), enquanto que para os diabéticos tipo 2, nove apresentavam RD, ou seja, 14\%. O índice geral para todos os diabéticos foi de 12 casos (13\% do total).

\section{Tipo de DM X Presença de RD (em \%)}

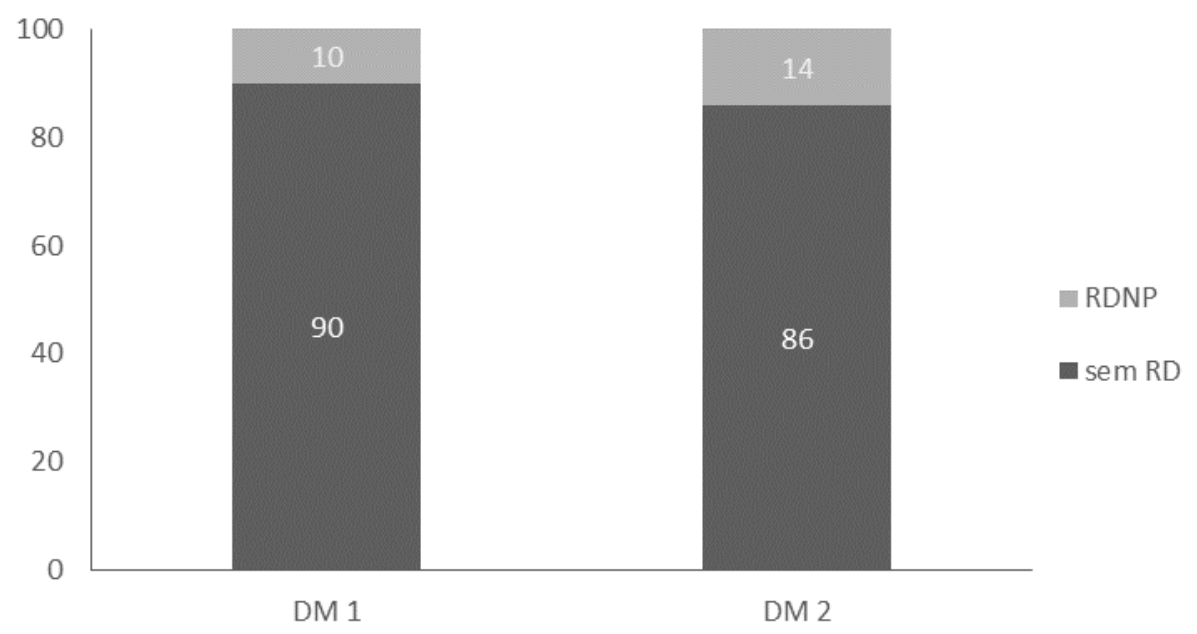

Gráfico 2- Diagnóstico de retinopatia diabética em função do tempo do tipo de diabetes (em frequência). Legenda: RDNP: Retinopatia diabética não proliferativa. 
Em relação ao índice glicêmico, a população de diabéticos estudada apresentou uma média de 164,2 $\mathrm{mg} / \mathrm{dL}$ (desvio padrão=70). Entre aqueles com RD, a média foi de 199,7 mg/dL (desvio padrão=108,1), variação entre 86 e 442 mg/dL, enquanto que entre os que não apresentam a complicação, a taxa glicêmica variou entre 60 e 407 $\mathrm{mg} / \mathrm{dL}$, com média de 159,6 mg/dL (desvio padrão=61,9). Apesar do grupo com RD apresentar uma taxa glicêmica relativamente maior que o grupo sem a patologia, a glicemia não está associada, nesta amostra, com a presença de RD $(\mathrm{p}=0,094)$. No entanto, a literatura associa tal fator ao aparecimento de RD. O fato de haver temporalmente uma variação tão grande na taxa glicêmica, bem como o número pequeno de pacientes com RD, podem explicar tal discrepância.

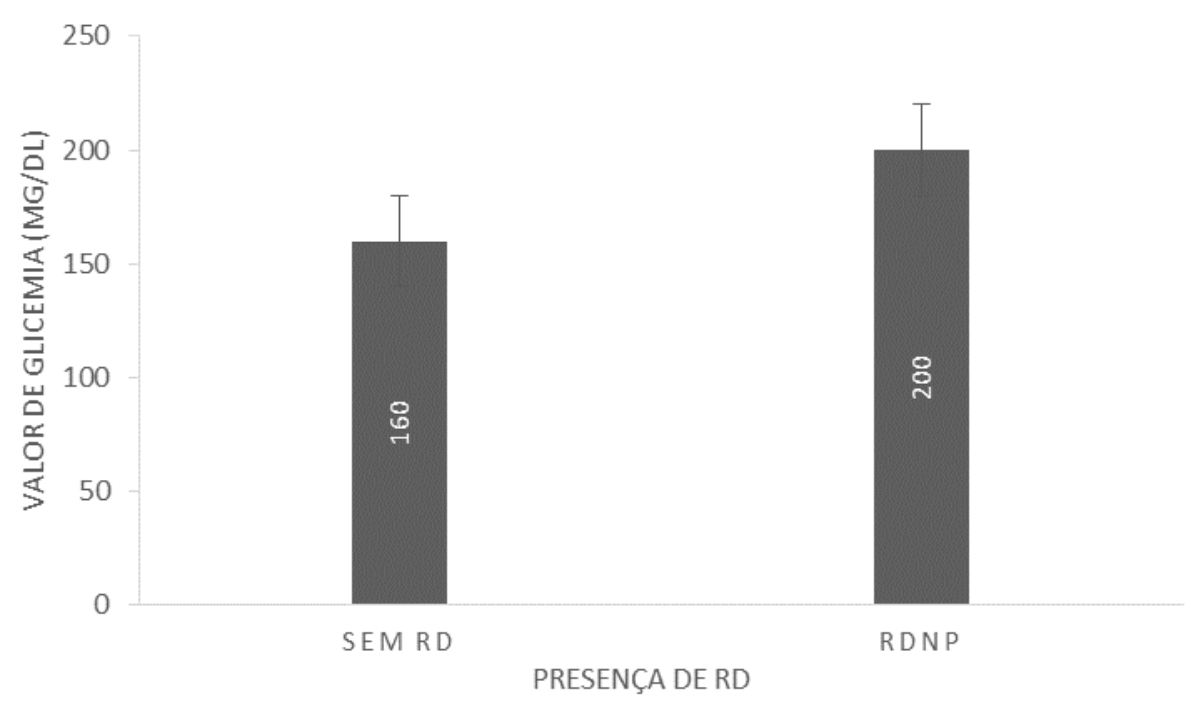

Gráfico 3- Diagnóstico de retinopatia diabética em função da taxa glicêmica (mg/dL). As linhas representam o desvio padrão da média. Legenda: RDNP: Retinopatia diabética não proliferativa.

Os dados demográficos relacionados aos participantes do grupo controle estão dispostos na Tabela 4 (idade, gênero, acuidade visual com correção e antecedentes familiares). Os dados brutos obtidos para cada participante do grupo controle encontram-se em anexo (ANEXO D). 
Tabela 4- Características dos participantes controles do estudo (Idade, Gênero, Acuidade Visual e Antecedentes Familiares de DM).

\begin{tabular}{|c|c|c|}
\hline \multicolumn{3}{|l|}{ Idade (anos) } \\
\hline \multicolumn{3}{|l|}{ Menor valor: 17 anos; } \\
\hline Maior valor: 69 anos; & Média: 38,38 & DP: 12,81 \\
\hline Gênero, n (\%) & Mulheres: 73 (64\%) & Homens: 41 (36\%) \\
\hline AVcc (em logMAR) & Pior resultado: 0,3 & Melhor resultado: -0.3 \\
\hline \multirow[t]{2}{*}{$A F, n(\%)$} & & -Não: 50 (44\%) \\
\hline & Sim: 58 (51\%) & $-\mathrm{NA}^{1}: \mathrm{6}(5 \%)$ \\
\hline Olho Testado, $n$ (\%) & OD: 63 (55\%) & OE: $51(45 \%)$ \\
\hline
\end{tabular}

\subsection{Visão de Cores}

Os dados expostos a seguir referem-se ao desempenho (valores de limiar) dos participantes no primeiro protocolo do CCT, o Trivector. Quanto menor o valor obtido, melhor a discriminação de cores naquele eixo de confusão. No grupo controle, os resultados variaram entre 22 e 128 no eixo protan, entre 22 e 165 no eixo deutan e entre 26 e 224 no tritan. Já para os diabéticos, os resultados variaram entre 23 e 1100 para o eixo protan, entre 20 e 928 para o eixo deutan e 27 e 762 para o eixo tritan.

Os resultados são apresentados em relação aos valores de limiar para três eixos de confusão de cores (protan, deutan e tritan) e leva em consideração a média de desempenho em cada eixo para cada um dos grupos examinados (controles e diabéticos). 


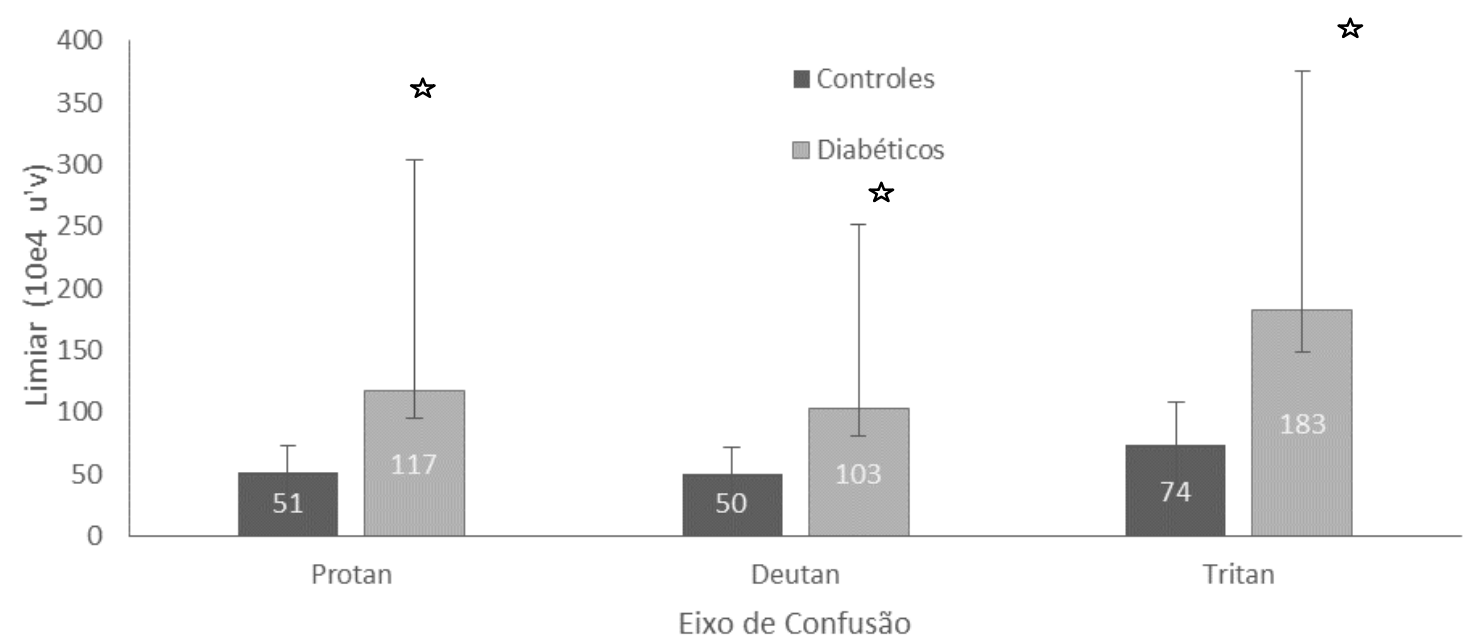

Gráfico 4- Valores de limiar no CCT para cada um dos eixos de confusão de cores, para cada um dos grupos avaliados. As linhas representam o desvio padrão da média. Os valores de média encontram-se nas barras. A $\star$ indica significância.

O desempenho dos controles no Trivector foi significativamente maior que o dos diabéticos $(\mathrm{p}=0,001$ para o eixo protan; $\mathrm{p}=0,001$ para o eixo deutan e $\mathrm{p}=0,000$ para o eixo tritan).

Com relação ao diagnóstico de RD na população diabética, os pacientes que apresentaram tal complicação obtiveram um desempenho que variou entre 29 e 1100 para o eixo protan, entre 33 e 1000 para o eixo deutan e entre 66 e 1100 para o eixo protan. As médias para cada grupo são mostradas no gráfico 5 .

- Sem RD $\quad$ RDNP

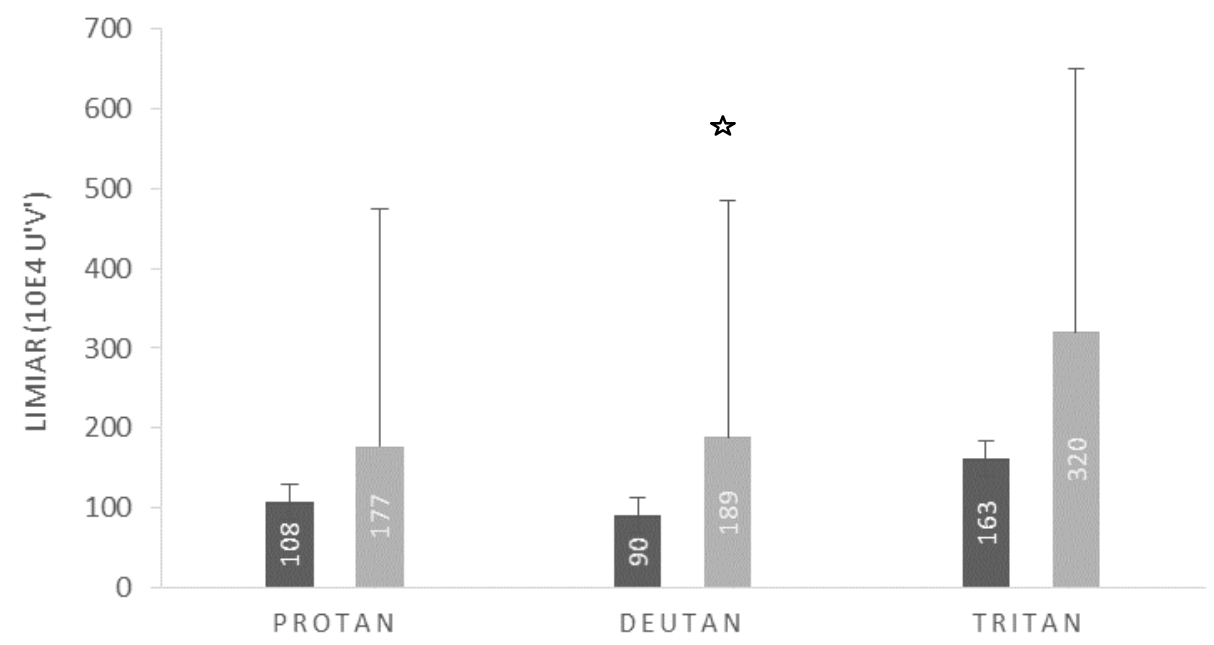

Gráfico 5- Valores de limiar no CCT em função da presença de retinopatia diabética. As linhas representam o desvio padrão da média. Os valores de média encontram-se nas barras. indica significância. RDNP: retinopatia diabética não proliferativa. 
A presença de RD não foi significativa para os resultados dos participantes diabéticos, exceto para o eixo deutan (Protan: $p=0,241$, Deutan: $p=0,03$ e Tritan: $p=0,08$ ). O desvio padrão foi grande, pois há uma variação considerável no resultado do CCT dentro do grupo com RDNP.

Com relação ao tempo de diagnóstico de diabetes, os maiores resultados nos limiares de visão de cores encontraram-se aproximadamente entre 20 e 25 anos de diagnóstico. Os valores encontram-se expostos no Gráfico 6.

Uma hipótese a ser levantada aqui é que há maior possibilidade de desenvolvimento de RD dentro de 20 anos de diagnóstico, sendo que com este tempo de diagnóstico, cerca de $60 \%$ dos diabéticos tipo 2 apresentam a doença (SOCIEDADE BRAISLEIRA DE DIABETES). Desta forma, é esperado um maior dano na visão daqueles com maior tempo de doença. Outro fator é que há poucos pacientes com mais de 25 anos de diagnóstico (10 participantes). Assim, os dados referentes ao tempo de doença podem mostrar este viés da própria amostra.

\section{TEMPO DE DIABETES X TRIVECTOR}

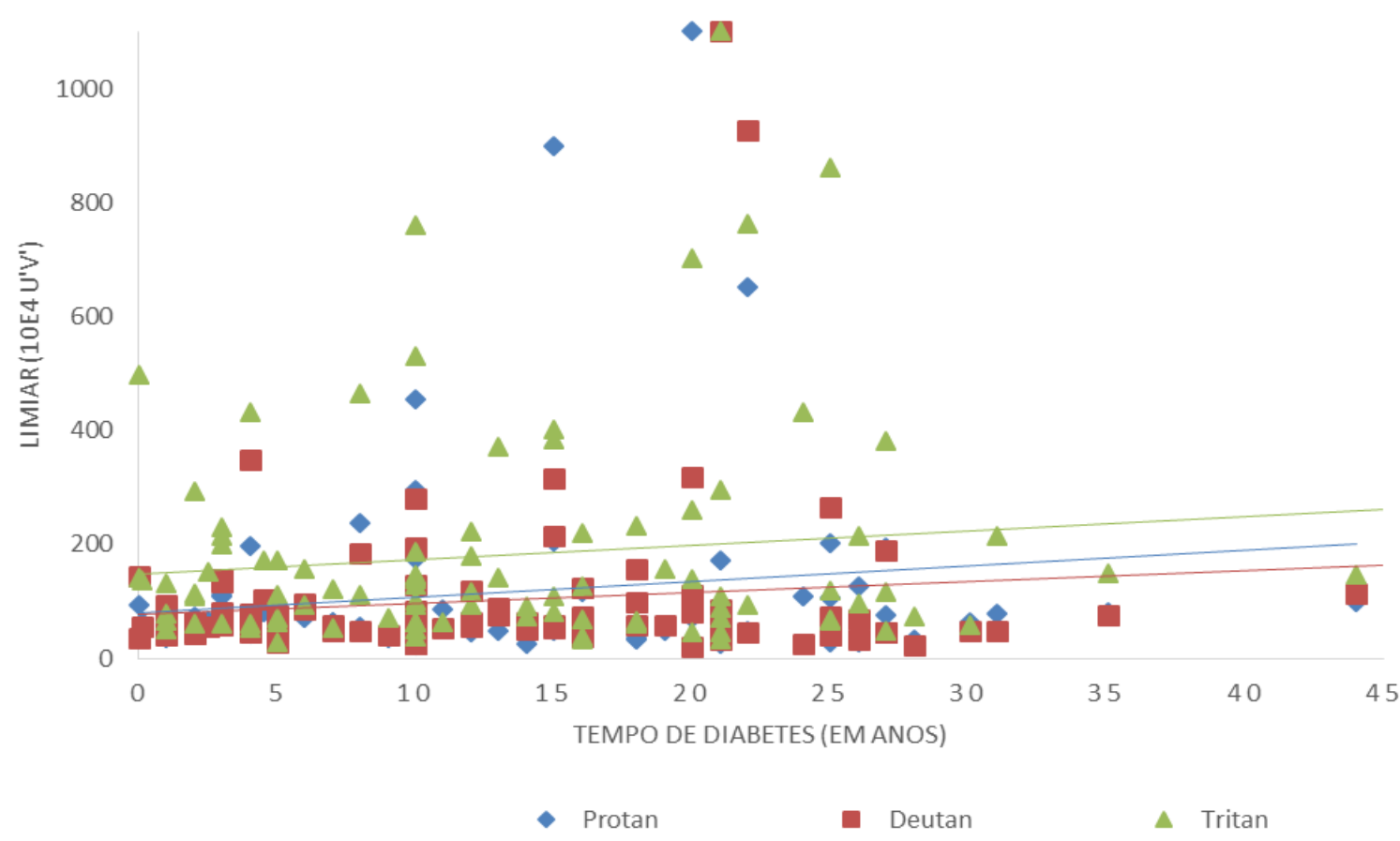

Gráfico 6- Valores de limiar no CCT em função do tempo de diagnóstico de diabetes (em anos). As linhas representam a tendência linear para cada um dos eixos de confusão de cor. 
Em termos dos limiares no eixo de confusão de cores em relação ao tipo de diabetes apresentado, os resultados variaram, para DM tipo 1, entre 26 e 128 para o eixo protan, entre 20 e 140 para o eixo deutan e entre 32 e 372 para o eixo tritan. Para DM tipo 2, os resultados variaram entre 23 e 1100 para o protan, entre 26 e 1100 para o deutan e entre 27 e 1100 para o tritan. As médias para cada grupo encontram-se no gráfico 7, abaixo:

\section{Trivector X Tipo de Diabetes}

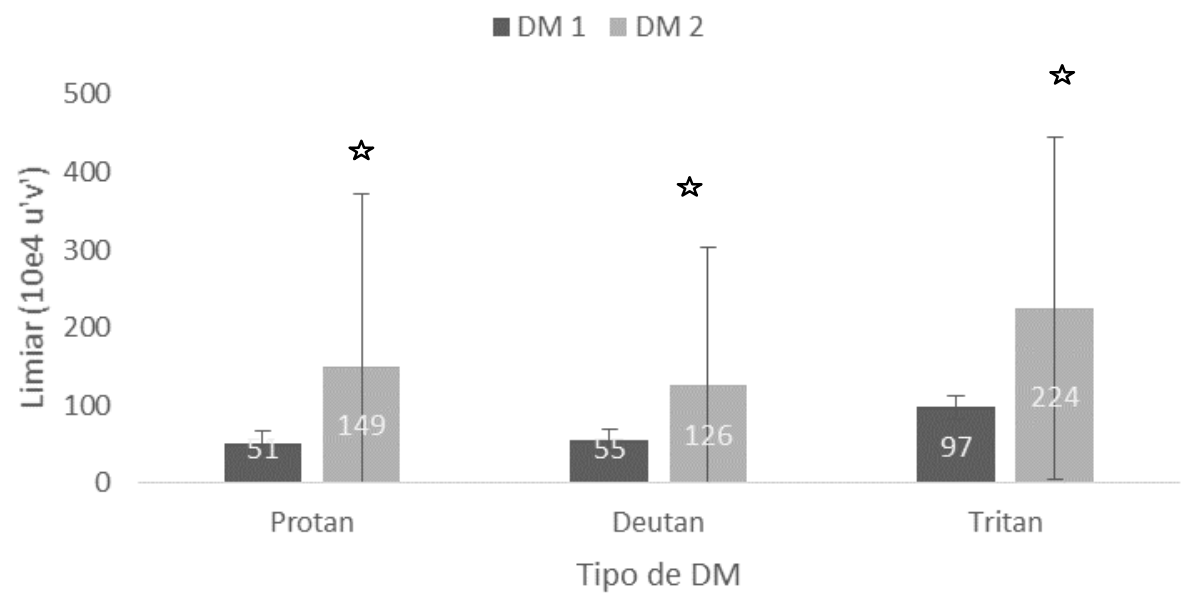

Gráfico 7- Valores de limiar no CCT em função do tipo de diabetes. As linhas representam o desvio padrão da média. Os valores de média encontram-se nas baß̧łas. A indica significância. DM: Diabetes Mellitus.

O tipo da doença foi significante para um pior resultado no eixo de confusão de cores (Protan: $\mathrm{p}=0,016$; Deutan: $\mathrm{p}=0,030$; Tritan: $\mathrm{p}=0,002$ ). Os diabéticos do tipo 2, portanto, apresentaram uma visão de cores pior que aqueles do tipo 1. Este resultado vai de encontro com os dados que mostram uma prevalência maior de RD entre os pacientes com DM tipo 1. Houve uma variação ampla entre o tempo de diagnóstico entre ambos os tipos de DM (entre um e 35 anos para DM tipo 1 e entre um mês e 44 anos para DM tipo 2), o que poderia explicar este resultado. No entanto, a amostra do presente estudo não é grande o suficiente para se obter dados epidemiológicos, o que pode vir a ser uma restrição para alguns resultados, mas foi suficiente para mostrar resultados entre os grupos. Além disto, os pacientes tipo 1 que participaram do estudo são relativamente mais jovens que os tipo 2 , fator que pode ter influenciado tal resultado. 
Com relação à taxa glicêmica, não houve correlação com os resultados do Trivector, para os três eixos de confusão de cor. Assim, os maiores resultados nos limiares de confusão de cores não foram encontrados entre aqueles com maior taxa glicêmica, como mostra o gráfico 8. A média para os três eixos de confusão de cores para os pacientes com taxa glicêmica acima de $200 \mathrm{mg} / \mathrm{dL}(\mathrm{n}=20)$ foi de 72 no eixo protan (desvio padrão= 47), de 62 no eixo deutan (desvio padrão=44) e de 141 (desvio padrão=128) para o eixo tritan. Este resultado está de acordo com o esperado, pois não foi apontada na literatura alguma associação entre a taxa glicêmica e uma possível piora na visão de cores.

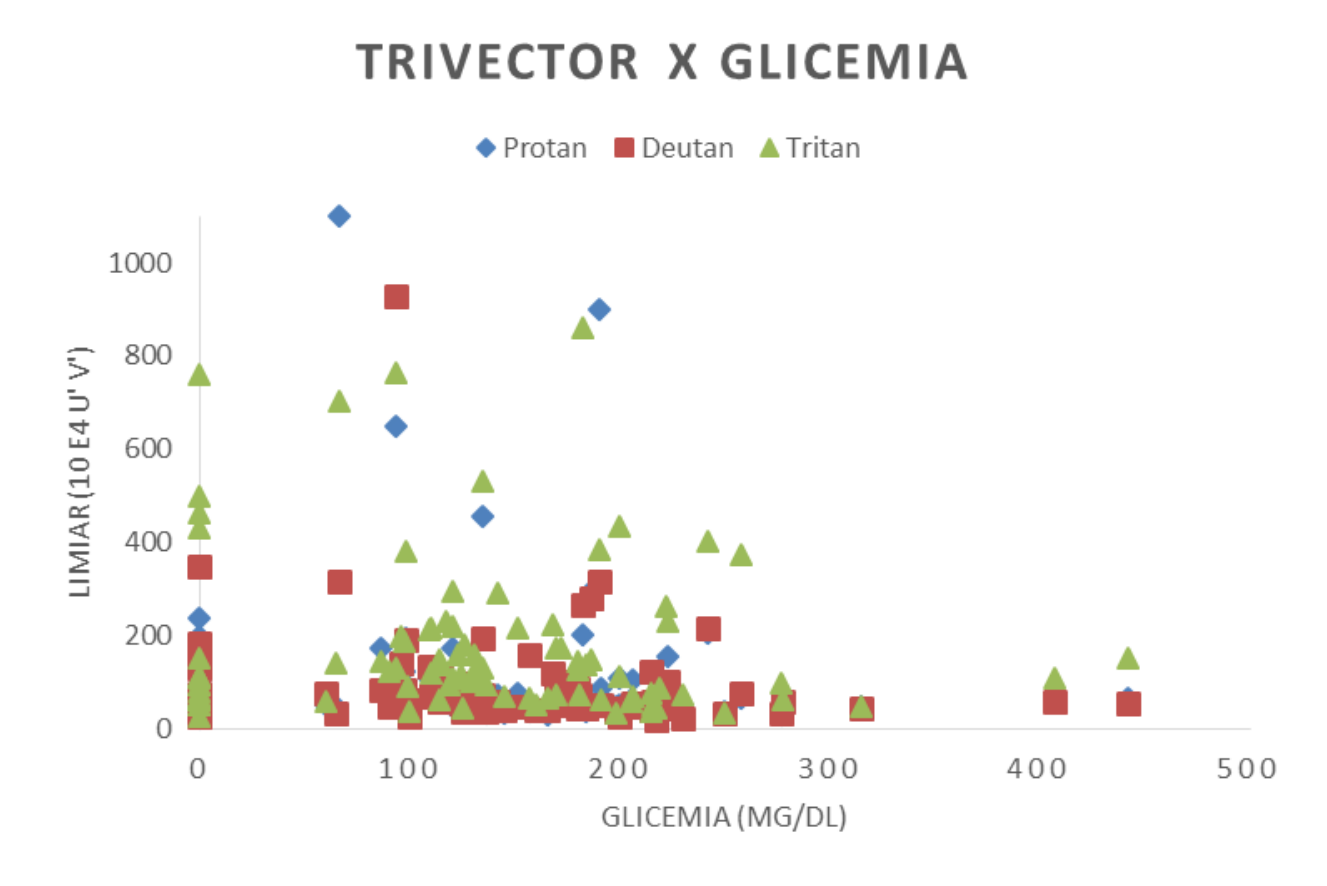

Gráfico 8- Valores de limiar no CCT em função da taxa glicêmica (em mg/dL).

Com relação ao protocolo das Elipses, os resultados (comprimento, semieixos, ângulo e área) obtidos pelos participantes controles encontram-se na tabela 5, abaixo. Já para os participantes DM, os dados obtidos encontram-se na Tabela 6. Os valores para a Elipse de discriminação de cores para os diabéticos foram maiores que para os controles, sendo sugestivo de uma pior discriminação de cores no caso dos DM. 
Tabela 5- Média para os valores de Comprimento, semi-eixos, ângulo e área para Elipse de Discriminação de cores gerada para participantes CTRL.

Elipse 1
\begin{tabular}{|l|r|r|}
\hline Comprimento & Média & \multicolumn{1}{c|}{ DP } \\
\hline Semi-eixo maior & 0,01748 & 0,0099 \\
\hline Semi-eixo menor & 0,00874 & 0,0050 \\
\hline Ângulo & 0,00495 & 0,0073 \\
\hline Área x $10^{6}$ & 85,91504 & 25,0854 \\
\hline
\end{tabular}

OBS: Em unidades $u^{\prime} v^{\prime}$

Tabela 6- Média para os valores de Comprimento, semi-eixos, ângulo e área para Elipse de Discriminação de cores gerada para participantes DM.

Elipse 1

\begin{tabular}{|l|r|r|}
\hline Comprimento & 0,16832 & 1,0199 \\
\hline Semi-eixo maior & 0,08416 & 0,4876 \\
\hline Semi-eixo menor & 0,01001 & 0,0164 \\
\hline Ângulo & 83,50000 & 26,8108 \\
\hline Área x 106 & 5277,21898 & 27974,0035 \\
\hline
\end{tabular}

OBS: Em unidades $u^{\prime} v^{\prime}$

As elipses de discriminação geradas para pacientes e controles encontram-se nos Gráficos 9 e 10, abaixo. Nota-se que a área da elipse de discriminação de cores dos pacientes diabéticos é maior para os DM, o que indica uma pior discriminação de cores neste grupo. No entanto, para as associações com a presença de RD, tempo de DM, tipo de DM e glicemia na data do teste, preferiu-se trabalhar com os dados obtidos através do protocolo Trivector, por este apresentar valores inteiros e por permitir um melhor manuseio estatístico dos dados. Porém, a elipse ajuda a visualizar a diferença de desempenho entre os dois grupos. 


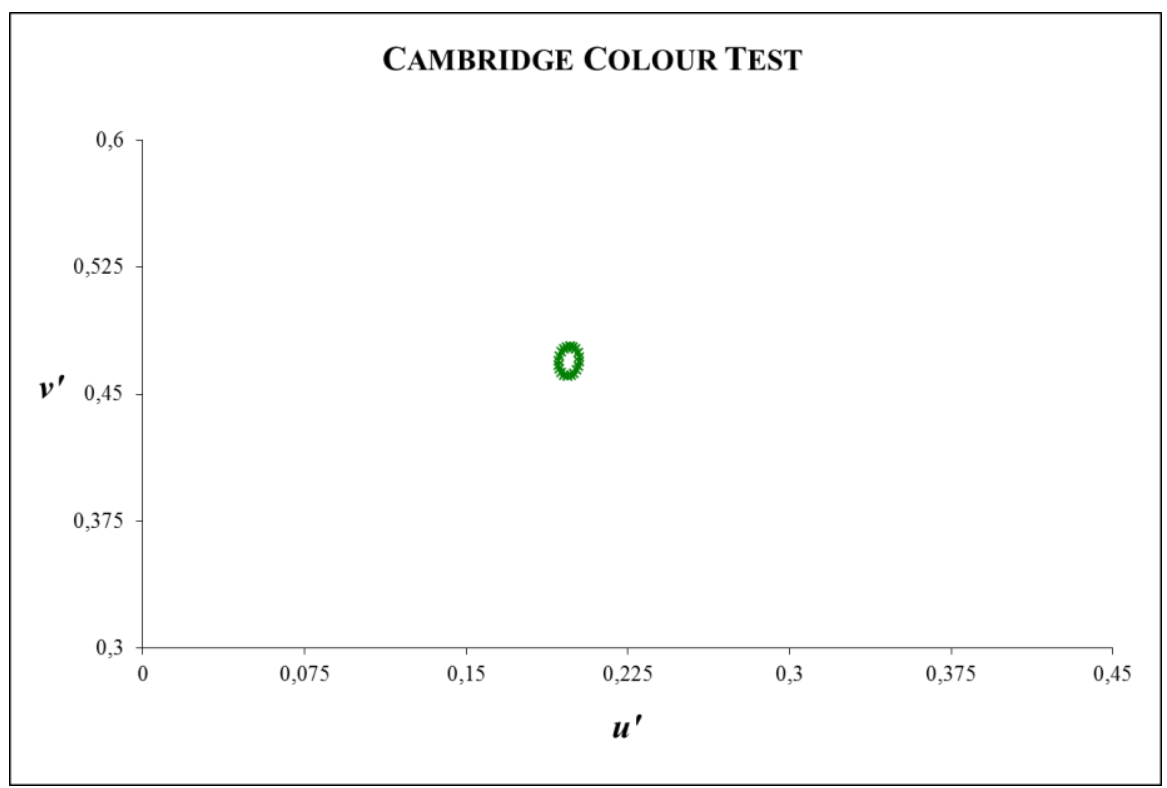

Gráfico 9- Elipse de discriminação de cores para controles, em unidades u’v'.

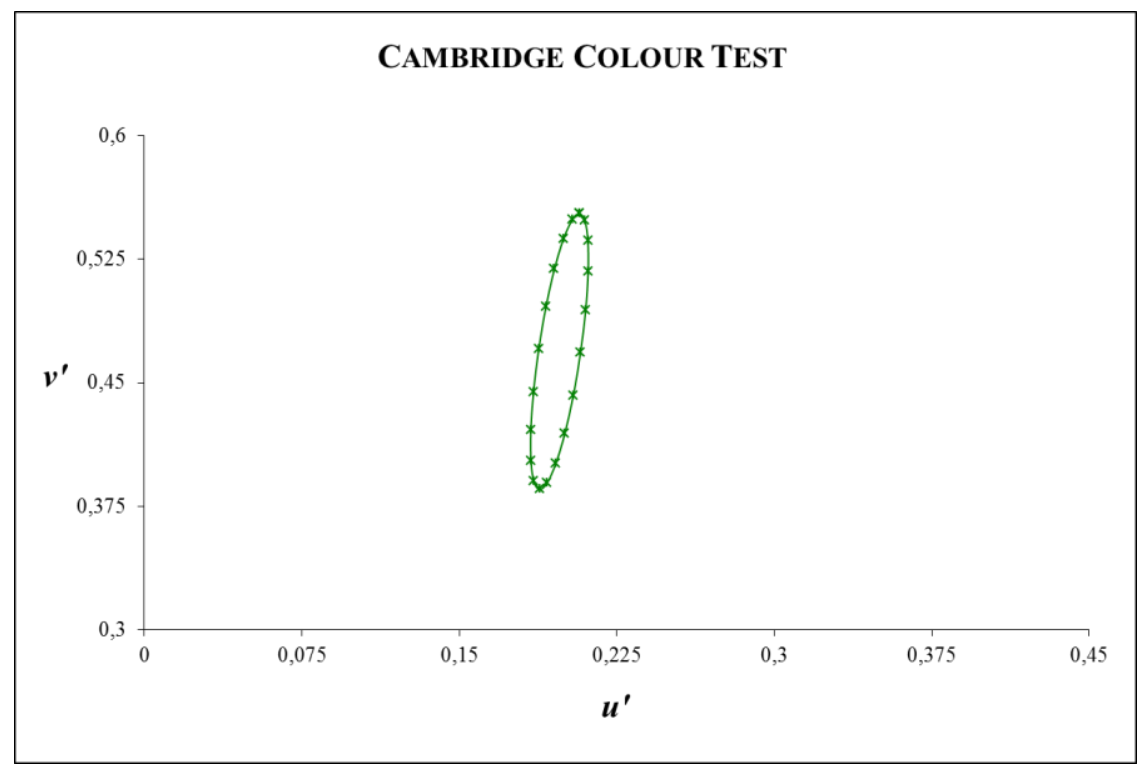

Gráfico 10- Elipse de discriminação de cores para pacientes diabéticos, em unidades u'v'.

\subsection{Genótipo}

Os dados expostos a seguir referem-se aos diversos parâmetros avaliados (valores de limiar para Teste Trivector, presença de RD, tipo de DM, glicemia e antecedentes familiares de DM em Controles), em relação ao haplótipo apresentado. O tempo de diagnóstico de DM não será relacionado com o genótipo, já que o haplótipo não se modifica no decorrer da vida do indivíduo. Os valores obtidos referentes ao limiar de 
confusão protan para cada haplótipo no grupo controle variaram entre 26 e 106 para o TTA, entre 23 e 117 para o GCC e entre 26 e 128 para o heterozigoto. Já para os diabéticos, no mesmo eixo, os valores estiveram entre 29 e 456 para o TTA, entre 23 e 157 para o GCC e entre 26 e 1100 para o heterozigoto. A média dos resultados tanto para o grupo controle quanto para os diabéticos estão no gráfico 11, abaixo:

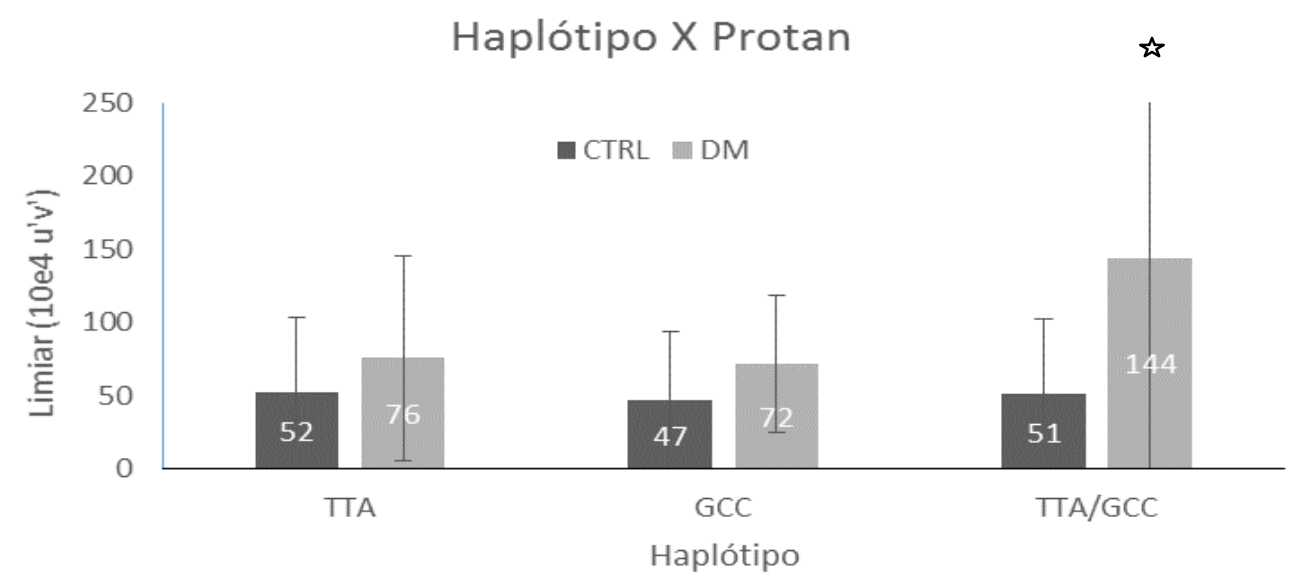

Gráfico 11- Valores de limiar para o eixo protan em função do haplótipo. As linhas representam o desvio padrão da média. Os valores de média encontram-se nas barras. A indica significância. CTRL: Controles; DM: Diabetes Mellitus.

Os resultados obtidos para o eixo protan indicaram significância $(\mathrm{p}=0,048) . \mathrm{Ou}$ seja, os diabéticos com haplótipo TTA/GCC tiveram um pior desempenho, se comparados com os controles. O melhor resultado correspondeu ao genótipo GCC, porém, sem significância $(\mathrm{P}=0,222)$. Já para os controles, não houve diferença entre os diferentes haplótipos.

Para o eixo deutan, os valores de limiar para o grupo controle ficaram em torno de 26 e 165 para aqueles com haplótipo TTA, de 30 a 79 para os GCC e de 23 a 101 para os heterozigotos. No caso dos diabéticos, os resultados para o mesmo eixo se encontram entre 20 a 194 para o haplótipo TTA, 26 e 100 para o GCC e entre 26 e 1100 para aquele com genótipo TTA/GCC. Os resultados (média para os grupos) estão expostos abaixo (Gráfico 12): 


\section{Haplótipo X Deutan}

-CTRL $=\mathrm{DM}$

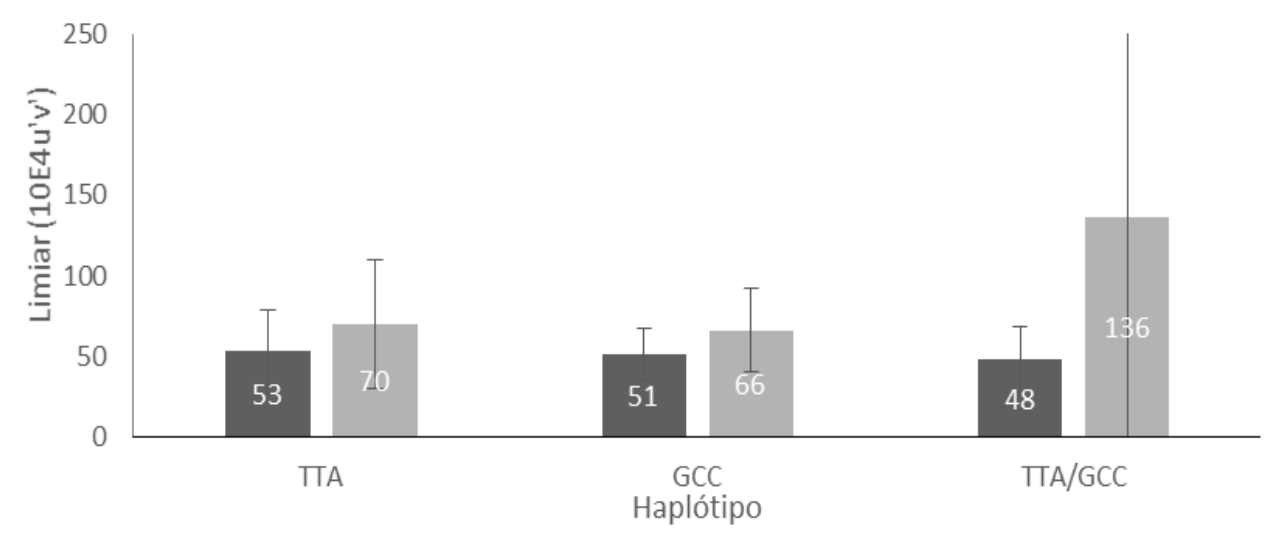

Gráfico 12- Valores de limiar para o eixo deutan em função do haplótipo. As linhas representam o desvio padrão da média. Os valores de média encontram-se nas barras. A indica significância. CTRL: Controles; DM: Diabetes Mellitus.

Não houve diferença entre os grupos para o eixo deutan $(\mathrm{p}=0,207)$. No entanto, o maior valor obtido foi com relação ao haplótipo TTA/GCC, assim como este grupo apresentou o maior desvio padrão.

Para o eixo tritan, os valores obtidos pelos participantes controles estavam entre 26 e 224 para o haplótipo TTA, entre 33 e 99 para o GCC e entre 26 e 147 para o haplótipo TTA/GCC. Já para os diabéticos, os valores ficaram entre 32 e 530 para o haplótipo TTA, entre 61 e 232 para o GCC e entre 27 e 1100 para o heterozigoto. As médias de cada grupo encontram-se no Gráfico 13 (abaixo): 


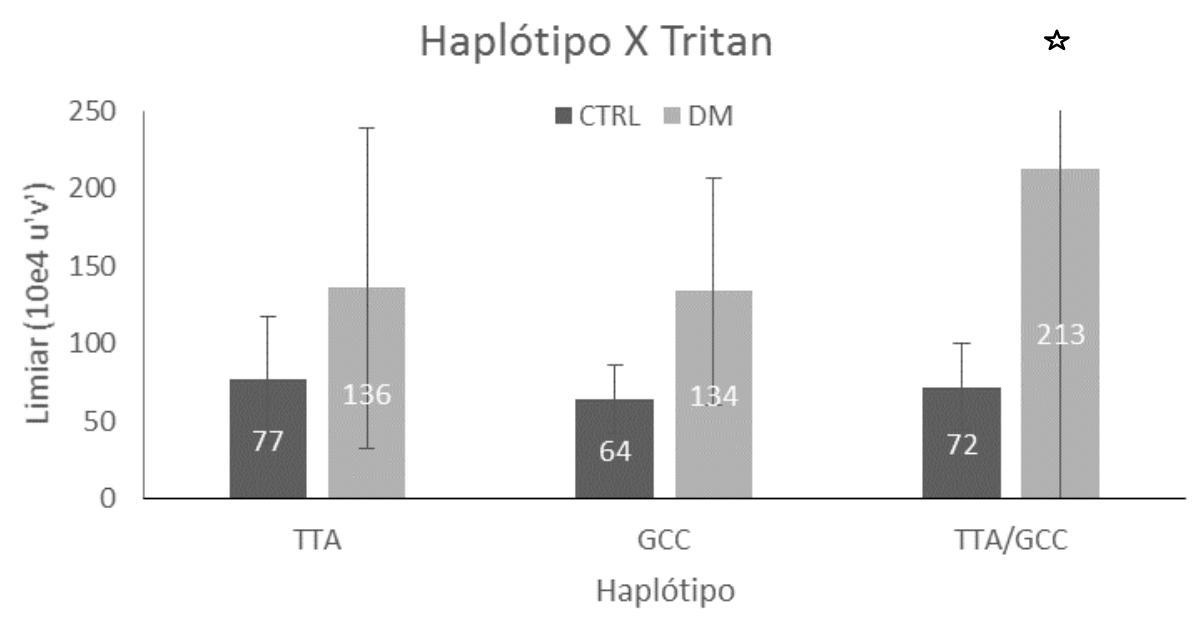

Gráfico 13- Valores de limiar para o eixo tritan em função do haplótipo. As linhas representam o desvio padrão da média. Os valores de média encontram-se nas barrał A indica significância. CTRL: Controles; DM: Diabetes Mellitus.

Para o eixo tritan, portanto, houve diferença entre os haplótipos $(\mathrm{p}=0,014)$, sendo o heterozigoto aquele com pior desempenho. Assim, não houve diferença para os outros dois grupos ( $\mathrm{p}=0,164)$. Para os controles, não houve diferença tampouco.

Sendo assim, para os diabéticos, o haplótipo TTA/GCC está associado a uma piora no desempenho do Teste Trivector, para os eixos protan e tritan. Para os controles, não houve diferença entre os genótipos.

Para o grupo de diabéticos sem o diagnóstico de RD, os valores variaram entre 29 e 456 para o eixo protan, entre 20 e 194 para o eixo deutan e entre 32 e 530 para o eixo tritan, considerando o haplótipo TTA. Já para o haplótipo GCC, os valores ficaram entre 23 e 157 para o eixo protan, entre 26 e 100 para o eixo deutan e entre 61 e 232 para o tritan. Para o heterozigoto, os valores foram entre 26 e 809 para o eixo protan, entre 26 e 928 para o eixo deutan e entre 27 e 762 para o eixo tritan.

O grupo com RD obteve os seguintes valores: entre 29 e 67 para o eixo protan, entre 33 e 74 para o eixo deutan e entre 97 e 153 para o tritan, para o haplótipo TTA; para o GCC, o único indivíduo obteve 47 no eixo protan, 73 no eixo deutan e 220 no eixo tritan. Para o heterozigoto, os resultados foram: entre 36 e 1100 para o eixo protan, entre 58 e 1100 para o eixo deutan e entre 66 e 1100 para o eixo tritan. As médias dos valores de limiar em cada eixo 
de confusão para os grupos com e sem RD, com relação ao genótipo, encontram-se no gráfico 14 , a seguir.

\section{Resultados do CCT em Função do Haplótipo X RD}

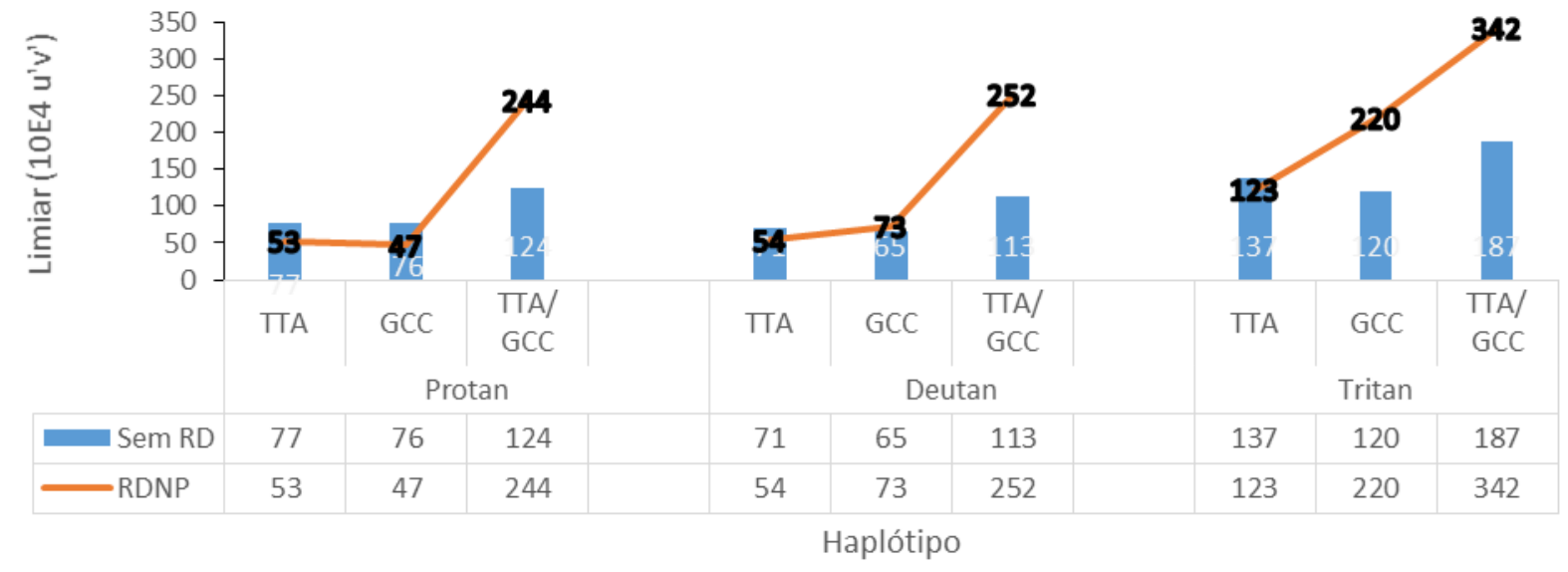

Gráfico 14- Valores de limiar para o teste CCT em função do haplótipo e da presença de RD. Os valores de média encontram-se nas barras e nas linhas. CTRL: Controles; DM: Diabetes Mellitus: RD: Retinopatia Diabética; RDNP: Retinopatia Diabética Não Proliferativa.

O grupo com RD apresentou o pior valor, no entanto, os resultados não indicaram que tal diferença seja significativa $(\mathrm{p}=0,344)$. No entanto, há um aumento nos resultados para o grupo com RD. A falta de diferença pode refletir, nesta amostra, uma queda de desempenho já nos sujeitos sem RD, que pode significa uma perda precoce de função antes do estabelecimento das alterações morfológicas e vasculares que assinala o diagnóstico da retinopatia.

Os diabéticos tipo 1 e tipo 2 também apresentaram limiares diversos para o CCT. Para os de tipo 1, os resultados variaram entre 29 e 128 no eixo protan, entre 20 e 140 para o eixo deutan e entre 32 e 199 para o eixo tritan, considerando o haplótipo TTA. Já para os heterozigotos tipo 1, os resultados variariam entre 26 e 80 para o eixo protan, entre 40 e 70 para o deutan e entre 51 e 372 para o eixo tritan. Não houveram diabéticos tipo 1 com o haplótipo GCC.

Para os diabéticos tipo 2, os limiares de visão de cores variaram entre 33 e 456 para o eixo protan, entre 36 e 194 para o deutan e entre 39 e 530 para o tritan, com relação ao TTA. Para os indivíduos de haplótipo GCC, os resultados variaram entre 23 e 157 para o eixo protan, entre 26 e 100 para o eixo deutan e entre 61 e 232 para o tritan. Os heterozigotos obtiveram um limiar entre 36 e 1100 para o eixo protan, entre 26 e 1100 para 
o deutan e entre o 27 e o 1100 para o tritan. O gráfico 15 mostra os valores médios obtidos no CCT, para cada haplótipo, em função do Tipo de DM.

\section{Resultados do CCT em Função do Haplótipo X Tipo de \\ DM}

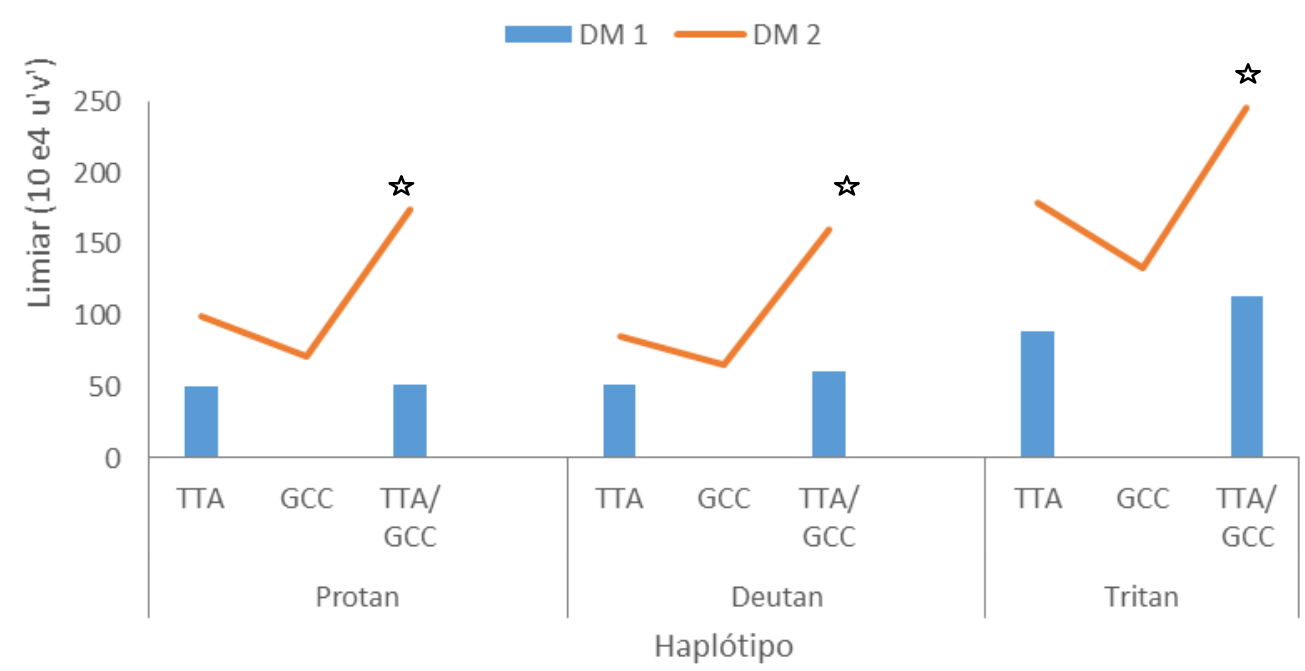

Gráfico 15- Valores de limiar para o teste CCT em função do haplótipo e do tipo de Diabetes Mellitus. Os valores de média encontram-se nas barras e nas linhas. CTRL: Controles; DM: Diabetes Mellitus: RD: Retinopatia Diabética; RDNP: Retinopatia Diabética Não Proliferativa. A $\longleftarrow$ indica significância.

Houve diferença entre os diversos genótipos relacionados ao Tipo de DM ( $\mathrm{p}=$ 0,012). Igualmente, o genótipo TTA/GCC está associado a uma piora maior na visão de cores de diabéticos Tipo 2. A partir deste resultado, pode-se questionar se o genótipo afeta de uma forma mais incisiva aqueles com o diabetes Tipo 2. Sendo assim, o perfil genético estaria sobremaneira relacionado a um dano na visão de cores, seja por interação com outros genes relacionados à DM tipo 2 ou por características inerentes à própria patologia, como idade mais avançada à época do diagnóstico.

Com relação à taxa glicêmica, os valores variaram entre 65 e 442 para o haplótipo TTA, entre 120 e 278 para o haplótipo GCC e entre 60 e 407 para o TTA/GCC. A média para cada um deles é exibida no gráfico 16. 


\section{Glicemia X Haplótipo}

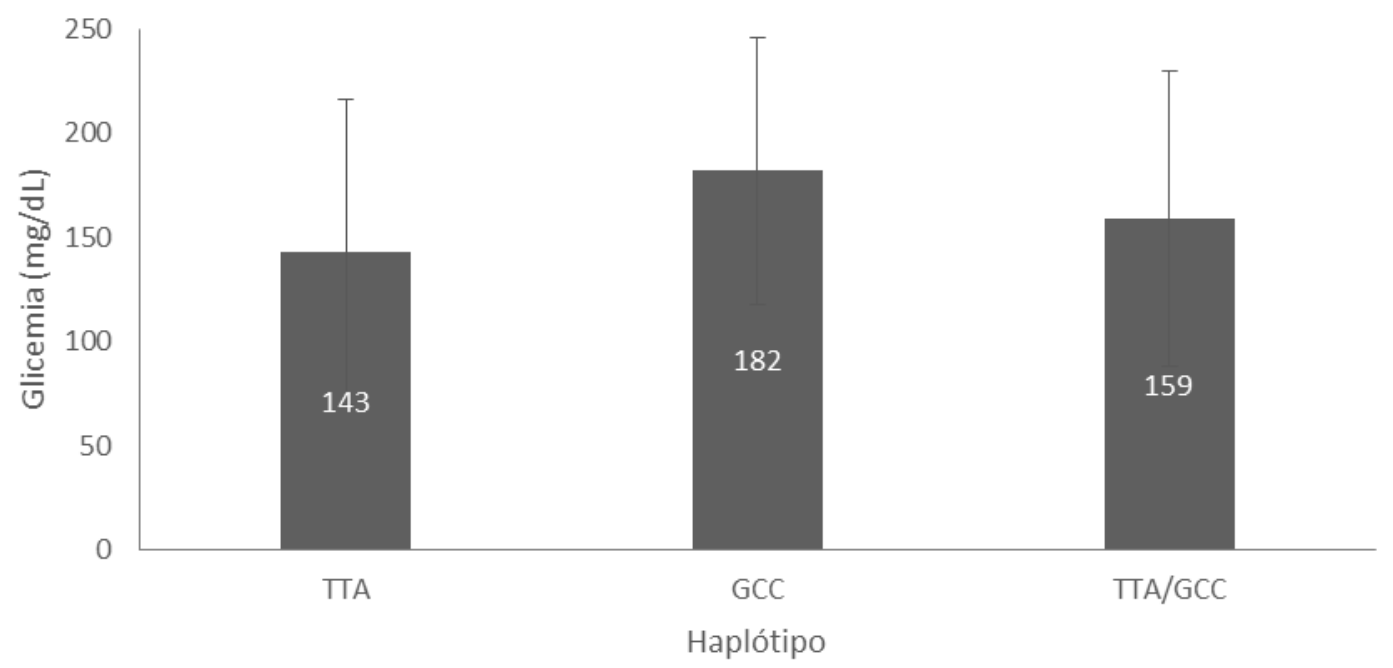

Gráfico 16- Média da taxa glicêmica (em mg/dL) para cada um dos haplótipos.

A taxa glicêmica não varia com o genótipo $(\mathrm{p}=0,528)$. Este resultado está de acordo com o esperado, já que não houve indicação na literatura que pudesse basear uma possível relação entre a expressão de EPO e a glicemia.

Para os controles, foi realização uma avaliação dos antecedentes familiares de DM para cada um dos haplótipos. Procedeu-se desta maneira pela maior probabilidade de desenvolvimento de diabetes entre aqueles que possuem familiares com a doença. Ou seja, apesar do sujeito não apresentar hiperglicemia no momento da coleta de dados, haveria uma chance aumentada de apresentar DM no futuro. A média dos limiares para cada um dos haplótipos em relação aos antecedentes familiares encontra-se no gráfico 17.

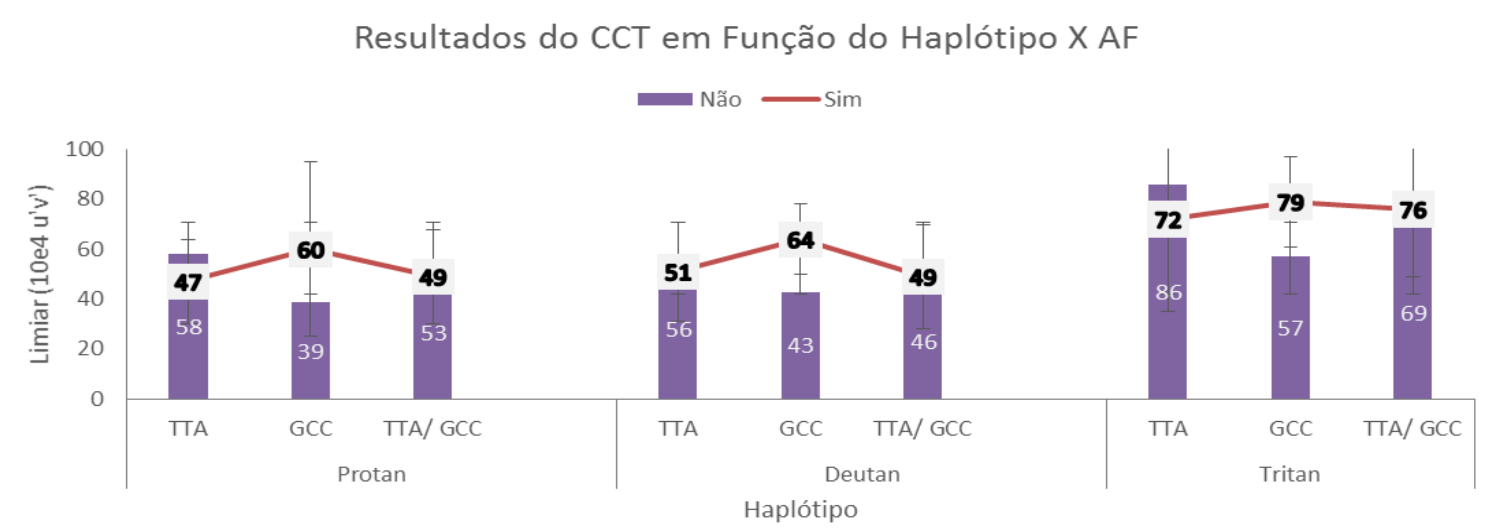

Gráfico 17: Valores de limiar para o teste CCT em função do haplótipo e dos antecedentes familiares de DM. Os valores de média encontram-se nas barras e nas linhas. As linhas verticais representam o desvio padrão da média. AF: Antecedentes Familiares. 
Os antecedentes familiares não influenciaram os resultados obtidos no CCT $(\mathrm{p}=0,90)$. De fato, a influência do genótipo no desempenho no teste de visão de cores não acontece até a instalação do quadro de DM, já que a partir de então, danos visuais passam a acontecer, inclusive entre os fotorreceptores (KERN, BERKOWITZ, 2015).

As Elipses de discriminação para os participantes DM, de acordo com o genótipo (haplótipo TTA, TTA/GCC e GCC, respectivamente) estão expostas nos gráficos 18, 19 e 20, abaixo.

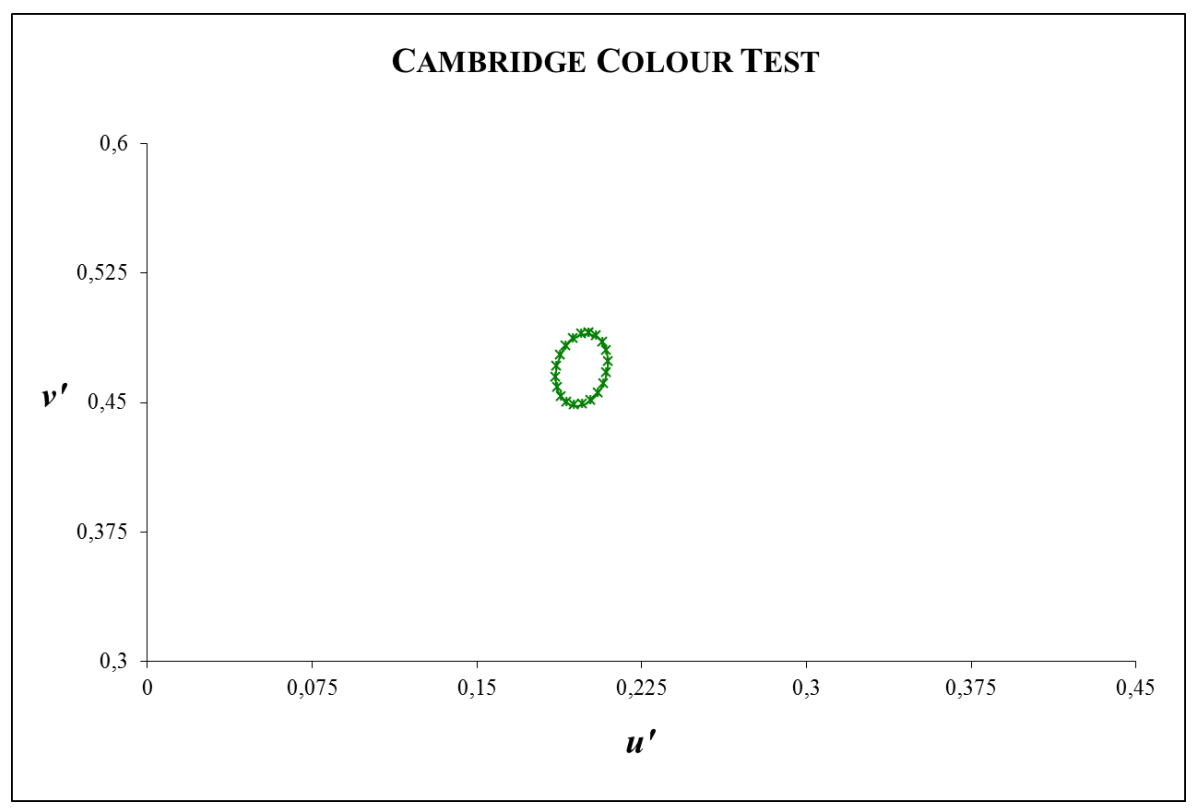

Gráfico 18- Elipse de discriminação de cores para pacientes diabéticos, com haplótipo TTA, em unidades u'v'.

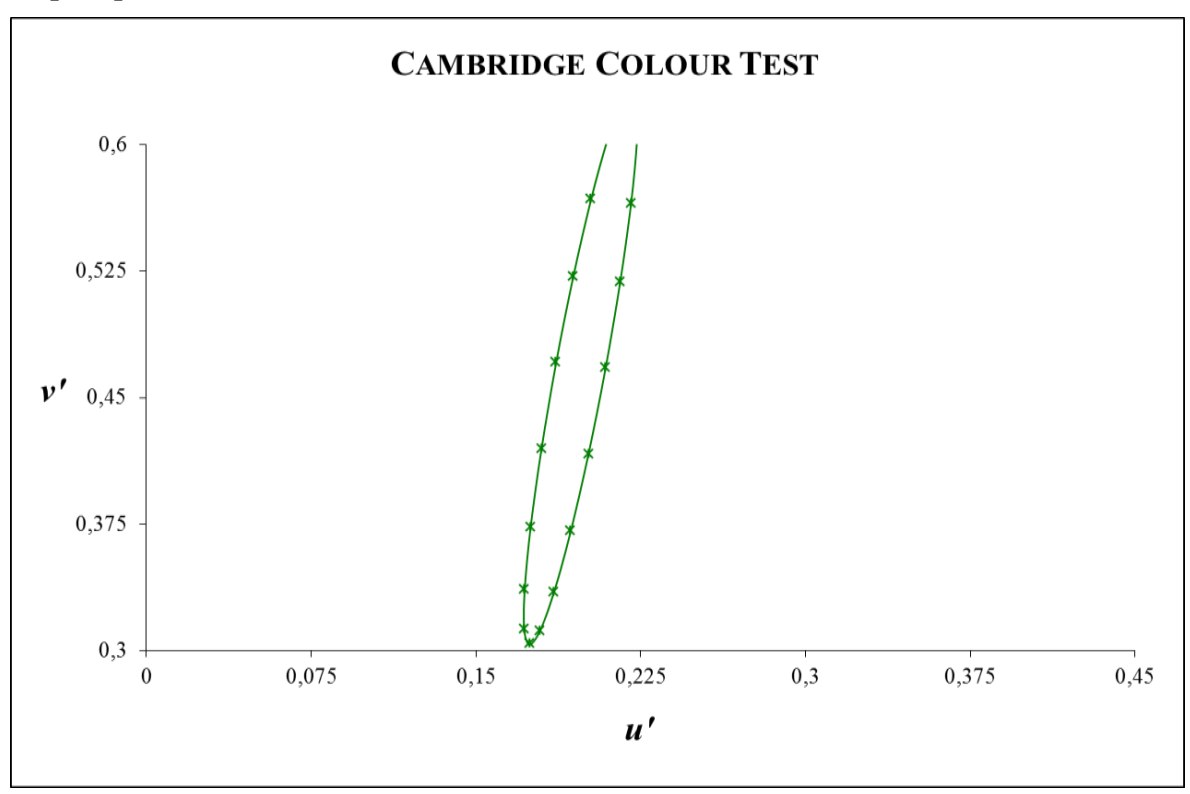

Gráfico 19- Elipse de discriminação de cores para pacientes diabéticos, com haplótipo TTA/ GCC, em unidades u'v'. 


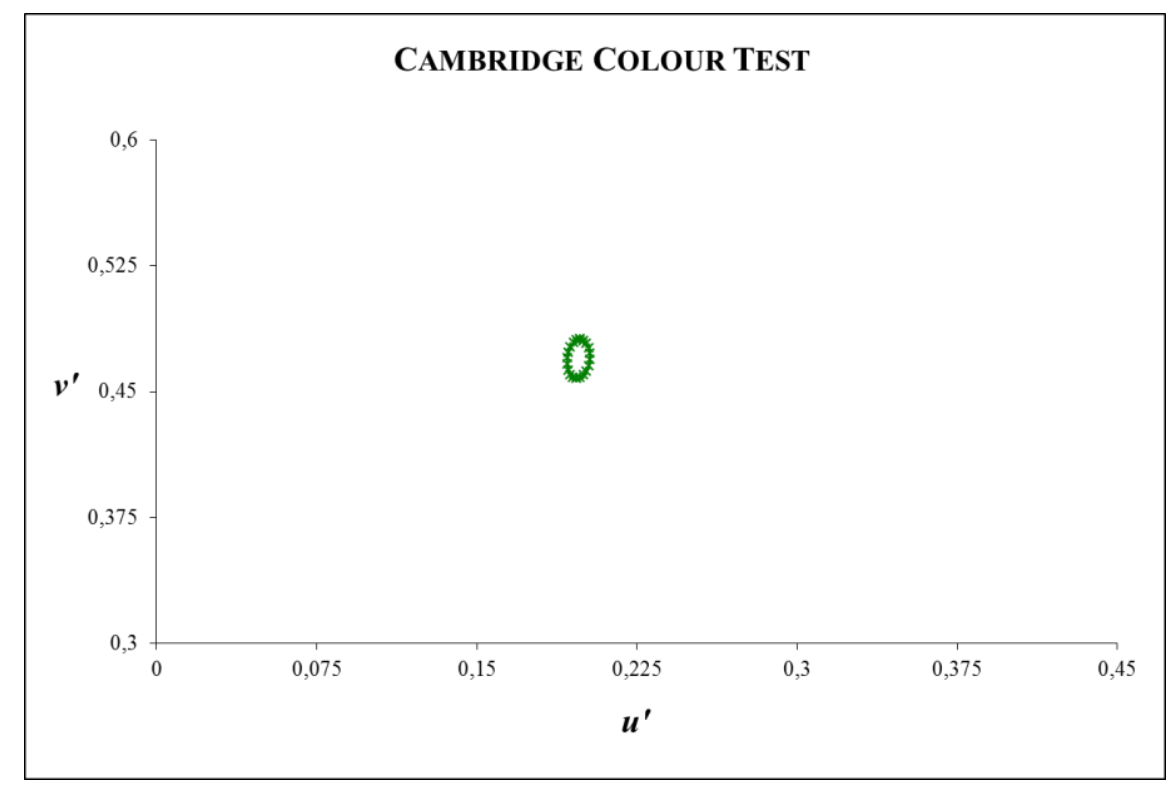

Gráfico 20- Elipse de discriminação de cores para pacientes diabéticos, com haplótipo GCC, em unidades u'v'.

Nota-se que a maior elipse de discriminação de cores refere-se aos diabéticos com genótipo TTA/GCC, ou seja, tal grupo possui uma pior discriminação de cores, avaliandose cada haplótipo. Os melhores resultados foram obtidos pelo grupo com haplótipo GCC, cuja elipse assemelha-se àquela obtida pelos controles e exibida no Gráfico 9. Tais dados sugerem que o genótipo GCC pode associar-se com resultados mais semelhantes que os obtidos pelos controles, o que pode ser indicativo de que tal haplótipo seja o genótipo protetivo, considerando a visão de cores de pacientes com DM. 


\section{DISCUSSÃO}


O objetivo deste trabalho foi investigar a associação entre o perfil genético para expressão de EPO e alterações funcionais na visão de cores de pessoas com diagnóstico de DM, averiguadas através de teste psicofísico. Dentre a população de diabéticos, o haplótipo TTA/GCC esteve associado a uma piora no desempenho do Teste Trivector, para os eixos protan e tritan. Para os controles, não houve diferença entre os genótipos, nem mesmo para aqueles com antecedentes familiares de DM. Os melhores resultados foram obtidos entre aqueles com o genótipo GCC.

O debate acerca da contribuição neuronal do desenvolvimento das alterações vasculares é intenso. Fotorreceptores foram identificados como um dos possíveis contribuintes no processo de angiogênese, pois são células que possuem grande demanda energética e, por isto, são mais suscetíveis à hipóxia (KERN, 2014). Apesar de trabalhos (KATSURA ET AL, 2005; GARCÍA-RAMIREZ ET AL, 2008) indicarem que inicialmente, fatores angiogênicos induzidos por hipóxia não afetam a produção local de EPO, em longo prazo, a hipóxia leva ao aumento da formação de neovasos, até mesmo como uma medida bioquímica de proteção neuronal (GARCÍA-RAMIREZ ET AL, 2008). Mesmo entre os pacientes sem diagnóstico de $\mathrm{RD}$, houve uma piora na visão de cores, em relação aos participantes controles, conforme averiguado pelo CCT. Tal achado pode ser sugestivo de que os fotorreceptores já mostram alterações significativas antes mesmo que transformações vasculares estejam presentes, o que está de acordo com as hipóteses aventadas na literatura. Assim sendo, os dados aqui apresentados podem ir ao encontro destes trabalhos anteriores, consistindo em mais uma evidência do papel dos fotorreceptores no surgimento da RD.

Para Barber (2003), o próprio quadro de DM gera efeitos diretos no metabolismo da retina, o que, consequentemente, leva ao aumento na apoptose de células neurais e à alterações na permeabilidade vascular. As alterações de fundo neural que levam à morte celular são irreversíveis. Além disto, não são detectáveis prontamente pelo paciente e nem em exames de rotina. Portanto, se para os componentes vasculares o tratamento pode mitigar os sintomas, com relação aos danos neurais, é necessário que a detecção de fatores potencialmente prejudiciais possa ser efetuada, poupando assim tais células da morte precoce. A possibilidade de encontrar variantes genéticas que possam aumentar a chance de desenvolvimento de tais alterações pode permitir a detecção precoce daqueles indivíduos que possam vir a apresentar alterações neurais de maneira mais contundente. $O$ uso de fatores antiangiogênicos para evitar os danos neurais na retina ainda não é totalmente difundido, pois os mecanismos bioquímicos envolvidos ainda não são plenamente conhecidos. Assim, estudos 
que visam compreender os mecanismos de ação dos diversos fatores envolvidos são fundamentais para que novas formas de tratamento possam atuar na diminuição dos danos verificados.

O presente estudo visou à associação entre alterações sugestivas de danos na visão de cores de pacientes com DM e determinado genótipo para expressão de EPO. Sendo assim, diversos trabalhos que visaram averiguar a relação entre danos neurais e a expressão de EPO o fizeram através de estudos bioquímicos e eletrofisiológicos. No entanto, este estudo buscou associações genótipo-fenótipo utilizando para tanto dados psicofísicos, que são sugestivos de danos neurais. Desta maneira, as alterações detectadas lançam luz sobre a influência do genótipo nas alterações precoces vistas no DM, mas também mostram possíveis dificuldades que os pacientes apresentam em decorrência de tais modificações.

Os resultados obtidos neste trabalho em associação com o perfil genético diferem daqueles encontrados na literatura. Tong e colaboradores (2008) indicaram o alelo TT para o EPO 16 como genótipo de risco para o desenvolvimento de complicações microvasculares na DM, bem como o alelo GG como genótipo protetivo. O trabalho citado também mostrou, baseado em trabalhos realizados in vitro, que o alelo TT tem um maior efeito na região promotora da EPO para a transcrição de RNA mensageiro. Os autores, no entanto, ressaltaram que o desenho do estudo in vivo envolveu tão somente a população caucasiana e que, apesar da frequência gênica do alelo não se alterar nas mais diversas etnias, isto poderia constituir-se uma limitação aos resultados obtidos.

Já Moemen e colaboradores (2013) encontraram o haplótipo GCC (para os SNPs rs1617640, rs507392 e rs551238) como genótipo de risco para desenvolvimento da RD proliferativa em pacientes com DM tipo 2. Um dos motivos levantados pelos autores para tal discrepância diz respeito à não inclusão de pacientes com DM tipo 1 na amostra estudada, além do menor tempo de doença apresentado pelos participantes, em comparação com o estudo de Tong e colaboradores.

Além disto, Moemen e colegas (2013) postulam que o estudo conduzido por Tong levou em consideração também vasculopatias renais em diabéticos e que a EPO pode apresentar variações que atuam primordialmente em um tipo ou outro de tecido. De fato, níveis plasmáticos de EPO não estão associados com níveis locais da proteína (WATANABE ET AL, 2005), o que pode corroborar o postulado desses autores.

Outros pesquisadores (ABHARY ET AL, 2010) também encontraram o haplótipo GCC como genótipo de risco para a RD. Da mesma forma que a equipe de Moemen, tal 
estudo também não incluiu em sua amostra pacientes com nefropatia diabética, pois apesar de compartilharem mecanismos vasculares semelhantes, diferentes genes podem estar envolvidos na etiologia de ambas as doenças.

Portanto, não há ainda consenso na literatura sobre o genótipo de risco para RD. Assim, estudos mostram associação entre determinado haplótipo para expressão de EPO e o risco de desenvolvimento de RD (TONG ET AL, 2008; ABHARY ET AL, 2010; MOEMEN, 2013), para três SNPs estudados. No entanto, não há concordância entre as pesquisas realizadas acerca de qual o genótipo de risco para RD.

O presente estudo averiguou associação entre o haplótipo heterozigoto e uma piora na visão de cores, indicativa de danos difusos e funcionais na visão. Os diabéticos apresentaram piores resultados no teste de visão de cores, em comparação ao grupo controle. Assim sendo, o resultado obtido foi discrepante daqueles trazidos na literatura especializada. Novamente, um alelo oposto àqueles indicados em pesquisas anteriores foi associado com a mesma manifestação patológica.

Com relação à amostra, um dos principais entraves levantados com relação à pesquisa conduzida por Tong e colaboradores (2008) foi a pouca variedade étnica da amostra estudada. No presente trabalho, tal fator pode ter tido pouca influência nos resultados, já que a amostra contou com participantes das mais variadas etnias. A coleta de dados foi realizada primordialmente na cidade de São Paulo, local que congrega uma ampla gama de variantes genéticas. Por ter sido no passado (a ainda ser) um amplo polo imigratório e migratório, a cidade conta com sujeitos cujo genótipo apresenta maior heterogeneidade em comparação com os locais onde foram conduzidos os estudos citados.

O desenho amostral deste estudo abrangeu tanto DM tipo 1 quanto tipo 2. Os diabéticos tipo 2 apresentaram tanto piores resultados para o teste de visão de cores quanto uma maior associação entre o genótipo TTA/GCC e o pior desempenho na avaliação na visão de cores. No entanto, o fato da população de DM tipo 1 ter sido pequena na amostra pode ter influenciado tal resultado. Porém, Abhary e colegas (2010) também não encontraram associação entre o haplótipo e o desenvolvimento de RD proliferativa entre pacientes com DM tipo 1.

Assim, uma das hipóteses que pode explicar este achado está relacionada com uma possível variabilidade na EPO, ou na expressão da mesma, entre os tipos de DM. Apesar de compartilharem mecanismos bioquímicos relacionados à hiperglicemia, ambos os tipos de DM podem apresentar diferentes expressões de EPO no tecido retiniano. Tong e 
colaboradores (2008) encontraram que a concentração de EPO no humor vítreo de participantes com o alelo de risco TT foi 7,5 vezes maior que entre aqueles com o alelo GG. No entanto, a associação realizada pelos autores levou em consideração apenas a variante genética, sem considerar dados do estudo in vitro. Watanabe e colaboradores (2005) encontraram níveis significantemente aumentados de EPO no humor vítreo de diabéticos na presença de RD, em comparação àqueles sem a doença. Além disto, também demonstraram que os níveis de VEGF estavam aumentados concomitantemente à RD. Porém, os autores não consideraram o tipo de diabetes, apenas a presença ou não de retinopatia diabética. Assim sendo, não há dados que possam corroborar ou refutar uma possível diferença nos mecanismos bioquímicos da EPO em ambos os tipos de DM.

Além disto, divergências sobre quais alelos do mesmo SNP são associados com o perfil de risco da mesma doença já foram reportados. Assim, Li e colaboradores (2004) e Lin e colegas (2006) chegaram a alelos distintos para o SNP rs3741916 como genótipo de risco. Tal SNP pertence ao gene gliceraldeído-3-fosfato dehidrogenase, associado a uma maior incidência de doença de Alzheimer na população caucasiana (LI ET AL, 2004). Este fenômeno, caracterizado pela discrepância de resultados em pesquisas que visam delimitar um alelo de risco para o desenvolvimento de uma patologia, é conhecido como flip-flop. Pode ocorrer quando uma associação de locus único é encontrada, mas em consonância com efeitos de múltiplos loci, que pode ser confundido como o efeito do locus único. Entre os estudos, também há variações, nas quais a magnitude de associação entre determinado alelo e a chance de desenvolver uma patologia varia entre diferentes populações. Um último fator diz respeito à relação entre determinado alelo e o fenótipo, que em muitos casos, sofre interferência de fatores externos, inclusive os ambientais (LIN ET AL, 2006).

Em relação ao presente trabalho, a associação entre a RD e o genótipo ocorre com respeito ao SNP rs1617640, cujos efeitos são mediados por outros SNPs na mesma região alélica, especialmente os SNPs rs507392 e rs551238. Assim, é uma limitação deste tipo de estudo encontrar resultados diferentes para a mesma patologia pesquisada.

A variação na expressão gênica entre alelos é ocorre com bastante frequência e frequentemente está relacionada com susceptibilidade a diversas doenças (HOOGENDOORN ET AL, 2003). Tong e colaboradores (2008) encontraram uma concentração de EPO 7,5 vezes mais elevada no vítreo de não diabéticos com genótipo TT, em comparação com o haplótipo GG. Além disto, o alelo T causou um aumento na atividade promotora para EPO, não observada quando tal SNP foi eliminado via deleção ou substituição de $\mathrm{T}$ por outras 
bases. A substituição de $\mathrm{T}$ por $\mathrm{G}$ levou a uma menor expressão do que a deleção, o que pode ser indicativo de que o $\mathrm{G}$ possua um papel protetivo para a expressão de EPO.

$\mathrm{Na}$ pesquisa por nós conduzida, não foi apontada diferença entre os genótipos com relação ao desempenho no teste de visão de cores. Desta forma, o aumento de EPO não está relacionado a processos degenerativos na retina de pessoas sem DM. De fato, o aumento de tal hormônio pode representar uma vantagem, especialmente para atletas. Sendo promotor para a expressão proteica que leva à angiogênese, o gene EPO é um polimorfismo de melhora de desempenho (PEP- do inglês, performance enhancing polymorphism), já que aumenta a capacidade oxigenativa nos tecidos. Tanto que a utilização da EPO no esporte foi proibida em 1987, sendo considerada a partir de então, doping (BENTO ET AL, 2003; RIBEIRO, 2013). Em estudo realizado com 123 atletas corredores da cidade de Brasília, Ribeiro (2013) encontrou que heterozigotos para o SNP rs1617640 obtiveram uma vantagem aeróbica, enquanto que o genótipo GG possui desvantagem neste quesito. Além disto, o mesmo trabalho encontrou maior resposta ao óleo de pequi, um poderoso oxidante, naqueles atletas com o genótipo TT para diversos marcadores sanguíneos. Já no plaquetograma, tal pesquisa encontrou valores de respostas significativos apenas entre os indivíduos com genótipo TT ou TG. Os dados da pesquisa citada são compatíveis com nossas observações, pois o heterozigoto obteve o pior desempenho entre os grupos. Ou seja, enquanto o perfil heterozigoto para o gene EPO é um fator potencialmente patogênico na DM, com relação a indivíduos sem a doença, é uma vantagem.

Tanto Moemen e colegas (2013) quanto Tong e pesquisadores (2008) referiram-se primordialmente aos homozigotos para os SNPs estudados. Ou seja, ao se estudar o haplótipo ao invés do SNP, pudemos obter um perfil global de associação entre o gene EPO e danos neurais avaliados em teste de visão de cores. Sendo assim, o genótipo heterozigoto pode não ter sido parte do recorte dado por tais trabalhos, que visavam encontrar qual o alelo de risco para as complicações relacionadas à RDP. Da mesma forma, Abhary e colaboradores (2010) referiram-se especificamente ao alelo de risco. Desta maneira, pode-se considerar que sujeitos heterozigotos possuem tanto o alelo de risco indicado na pesquisa conduzida por Tong (2008), quanto o alelo indicado nas outras pesquisas.

Outro achado que corrobora a hipótese de que a alta expressão de EPO apenas se torna patogênica na ocorrência de DM relaciona-se com o fato de que não houve diferença entre o resultado dos controles, mesmo quando considerado os antecedentes familiares para DM. Ou seja, apenas após a instalação do quadro hiperglicêmico é que alterações na visão de 
cores podem ser vistas, já que é de se supor que dentre uma amostra de 58 controles com antecedentes familiares de até segundo grau, uma parcela irá desenvolver DM no futuro. Sendo assim, pode haver uma correlação entre a hiperglicemia e a modulação da EPO na RD, o que sugere um papel epigenético e ambiental importante na expressão do genótipo de risco para tal patologia. Faz-se necessário então a continuidade dos estudos que visem elucidar a relação entre fatores bioquímicos patológicos e a genética no desenvolvimento das complicações relacionadas à DM. 


\section{CONCLUSÕES}


Desta forma, conclui-se que dentre a população de diabéticos, o haplótipo TTA/GCC esteve associado a uma piora no desempenho do Teste Trivector, para os eixos protan e tritan. Os melhores resultados foram obtidos entre aqueles com o genótipo GCC, o que pode sugeri-lo como genótipo protetivo. Assim, na amostra estudada, o haplótipo heterozigoto é associado com uma piora no desempenho dos testes de visão de cores, enquanto que o haplótipo GCC é tido como fator protetivo da visão.

Além disso, para os controles, não houve diferença entre os genótipos, nem mesmo para aqueles com antecedentes familiares de DM. 
10. REFERÊNCIAS 
ABHARY, S.; BURDON, P.K.; CASSON, R.J.; GOGGIN, M.; PETROVSKI, N.P.; CRAIG, J.E. Association Between Erythropoietin Gene Polymorphisms and Diabetic Retinopathy, Arch Ophthalmol., 128(1):102-106, 2010.

ADAMS, A.J.; BEARSE, M.A.JR. Retinal Neuropathy precedes vasculopathy in diabetis: a function-based opportunity for early treatment intervention? Clin Exp Optom,. 95(3):256-65, May 2012.

AIELLO, L.P.; AVERY, R.L.; ARRIGG, P.G. Vascular endothelial growth factor in ocular fluid of patients with diabetic retinopathy and other retinal disorders. $N$ Engl $J$ Med, 331:1480-7, 1994.

AIELLO, L.P.; BURSELL, S.E.; CLERMONT, A.; DUH, E.; ISHII, H.; TAKAKI, C.; MORI, F.; CIULLA, T.A.; WAYS, K.; JIROUSEK, M.; SMITH, L.E.; KING, G.L. Vascular endothelial growth factor-induced retinal permeability is mediated by protein kinase $\mathrm{C}$ in vivo and suppressed by an orally effective $\beta$-isoform-selective inhibitor. Diabetes, 46:1473-1480, 1997.

AIELLO, L.P. Angiogenic Pathways in Diabetic Retinopathy. N. Engl J Med, 353 (8): 839-841, 2005.

AIZU, Y.; OYANAGI, K.: HU, J.; NAKAGAWA, H. Degeneration of retinal neuronal processes and pigment epithelium in the early stage of the streptozotocin-diabetic rats. Neuropathology, 22: 161-170, 2002.

AMANZADA, A.; GORALCZYK, A.D.; REINHARDT, L.; MORICONI, F.; CAMERON, S.; MIHM, S. Erythropoietin rs1617640 G allele associates with na attenuated rise of serum erythropoietin and a marked decline of hemoglobina in hepatites C patients undergoing antiviral therapy. BMC Infectious Diseases, 14:503, 2014.

ANAGNOSTOU, A.; LEE, E.S.; KESSIMIAN, N.; LEVINSON, M.; STEINER, M. Erythropoietin has a mitogenic and positive chemotactic effect on endothelial cells, Proc Natl Acad Sci USA, 87 (15): 5978-5982, 1990.

ANTONETTI, D.A.; KLEIN, R.; GARDNER, T.W. Diabetic retinopathy, Engl J Med, 366:1227-39, 2012. 
ANTONETTI, D.A.; LIETH, E. BARBER, A.J.; GARDNER, T.W. Molecular mechanisms of vascular permeability in diabetic retinopathy. Seminar in Ophthalmology, 14: 240-248, 1999.

BALASUBBU, S.; SUNDARESAN, P.; RAJENDRAN, A.; RAMASAMY, K.; GOVINDARAJAN, G,; PERUMALLSAMY, N.; HEJTMANCIK, J. F. Association analysis of nine candidate gene polymorphisms in Indian patients with type 2 diabetic retinopathy. BMC Medical Genetics, 11: 158, 2010.

BANGSTAD, H.J.; BRINCHIMANN-HANSEN, O.; HULTGREN, S.; DAHLJORGENSEN, K.; HANSSEN, K.F. Impaired contrast sensitivity in adolescents and young Type 1 (insulin-dependent) diabetic patients with microalbuminuria. Acta Ophalmologica, 72 (6): 668-673, 1994.

BARBER, A.J.; NAKAMURA, M.; WOLPERT, E.B.; REITER, C.E.N.; SEIGEL, G.M.; ANTONETTI, D.A.; GARDNER, T.W. Insulin rescues retinal neurons from apoptosis by a Phosphatidylinositol3-Kinase/Akt-mediated Mechanism that reduces the Activation of Caspase-3. The Journal of Biological Chemistry, 276(35), pp 32814-32821, August. 2001.

BARBER, A. J. A New view of Diabetic retinopathy: a neurodegenerative disease of the eye. Progress in Neuro-Psychopharmacology \& Biological Psychiatry 27, 283 - 290, 2003.

BECERRA, S.P..; AMARAL, J. Erithropoietin-An Endogenous Retinal Survival Factor. N Engl J Med, Vol. 347, 24: 1968-1970, 2002.

BENTO, R. M. A., DAMASCENO, L. M. P.; NETO, F.R.A. Eritropoetina humana recombinante no esporte: uma revisão. Rev. Bras. Med. Esporte, vol. 9, n .3, p. 169-180, 2003.

BONCI, D.M.O. Estudo dos pigmentos visuais de macaco-prego (Cebus sp) e da relação entre aspectos fisiológicos e genéticos da visão de cores em humanos. 2011. 155 f. Tese (Doutorado em Psicologia)-Instituto de Psicologia, Universidade de São Paulo, São Paulo, 2012.

BRINES, M.L. From the cover: erythropoietin crosses the bloodbrain barrier to protect against experimental brain injury. Proc. Natl. Acad. Sci. U.S.A.: 97, 2000. 
CHEN, J.; CONNOR, K.M.; ADERMAN, C.M.; SMITH, L.E. Erythropoietin deficiency decreases vascular stability in mice. J Clin Invest, 118: 526-533, 2008.

CHEUNG, N.B.; WONG, T.Y. Diabetic Retinopathy and systemic vascular complications, Progress in Retinal and Eye Research 27, pp. 161-176, 2008.

CHO, H.; SOBRIN, L. Genetics of Diabetic Retinopathy. Curr Diab Rep, 14: 515, 2014.

CIULLA, T.A.; AMADOR, A.G.; ZINMAN, B. Diabetic retinopathy and Diabetic Macular Edema. Pathophysiology, screening and novel therapies. Diabetes Care, 26: pp. 2653-2664, 2003.

COTRONEO, P.; RICERCA, B.M.; TODARO, L.; PITOCCO, D.; MANTO, A.; RUOTOLO, V.; STORTI, S.; DAMIANI, P.; CAPUTO, S.; GHIRLANDA, G. Blunted erythropoietin response to anemia in patients with Type 1 diabetes. Diabetes Metab Res Rev, 16: 172-176, 2000.

COSTA, M.F.; GOULART, P.R.K.; BARBONI, M.T.S.; VENTURA, D.F. Reduced Discrimination in the Trinanopic Confusion Line for Congenital Color Deficiency Adults. Front. Psychol, 7: 429, 2016.

CUNHA-VAZ, J.G. Characterization and Relevance of Different Diabetic Retinopathy Phenotypes in Diabetic Retinopathy. Editor: Gabriele E. Lang. Developments in Ophthalmology, Vol. 39: 13-30, 2007.

D'AGOSTINHO JR, R.B.; VASAN, R.S.; PENCINA, M.J.; WOLF, P.A.; COBAIN, M.; MASSARO, J.M. ET AL. General Cardiovascular Risk Profile for Use in Primary Care: The Framingham Heart Study. Circulation: 117: 743-753, 2008.

DEAN, F.M.; ARDEN, G.B.; DORNHORST, A. Partial Reversal of Protan and Tritan Colour Defects with Inhaled Oxygen in Insulin-dependent Diabetic Subjects. British Journal of Ophthalmology, 81:27-30, 1997. 
DIABETES CONTROL AND COMPLICATIONS TRIAL RESEARCH GROUP. The effect of intensive treatment of diabetes on the development and progression of long-term complications in insulin-dependent diabetes mellitus. New Engl J Med, 329: 977-86, 1993.

DIABETES CONTROL AND COMPLICATIONS TRIAL RESEARCH GROUP. The abserce of a glycemic threshold for the development of long-term complications: the perspective of the Diabetes Control and Complications Trial. Diabetes, 45: 1289-98, 1996.

DI LEO, M.A.S.; CAPUTO, S.; FALSINI, B.; PORCIATTI, V.; MINELLA, A.; GRECO, A.V.; GHIRLANDA, G. Nonselective Loss of Contrast Sensitivity in Visual System Testing in Early Type I Diabetes. Diabetes Care, 15(5): 620-624, 1992.

DRAZNIM, B.; EPSTEIN, S.; TURNER, H.E.; WASS, J.A.H. Oxford American Handbook of Endocrinology and Diabetes. Nova York: Oxford University Press, 2011.

ECKARDT, K.U. Erythropoietin and microvascular diabetic complications. Nephrol Dial Transplant, 24:388-390, 2009.

EL-ASRAR, A.M.A.; DRALANDS, L.; MISSOTTEN, L.; AL-JADAAN, I.A.; GEBOES, K. Expression of apoptosis markers in the retinas of human subjects with diabetes.Invest Ophthalmol Vis Sci., 45:2760-2766, 2004.

ERLICH, H.; VALDES, A.M.; NOBLE, J. (TEM MAIS) HLA DR-DQ haplotypes and genotypes and type 1 diabetes risk: analysis of the type 1 diabetes genetics consortium families. Diabetes, 57:1084, 2008.

FEITOSA-SANTANA, C.; OIWA, N.N.; PARAMEI, G.V.; BILMER, D.; COSTA, M.F.; LAGO, M.; NISHI, M.; VENTURA, D.F. Color space distortions in patients with type 2 diabetes mellitus, Visual Neuroscience, 23: 663-668, 2006.

FIGUEIRA, C.F.C. Epidemiologia da Retinopatia Diabética na Diabetes Mellitus Tipo I. 2010. Dissertação [Mestrado em Integrado em Medicina] - Faculdade de Medicina, Universidade de Coimbra, Coimbra, Portugal, 2010. 
FLETCHER, E.L.; PHIPPS, J.A.; WARD, M.M.; PUTHUSSERY, T.; WILKINSONBERKA, J.L. Neuronal and Glial Cell Abnormality as Perdictors of Progression of Diabetic Retinopathy. Curr Pham Des, 13(26): 2699-2712, 2007.

FONG, D.S.; FERRIS, F.L.; DAVIS, M.D.: CHEW, E.Y. ETDRS Research Group: Causes of severe visual loss in the Early Treatment Diabetic Retinopathy Study. ETDRS Report No. 24. Am J Ophthalmol, 127: 137-141, 1999.

FRANCO, L.J. Um problema de saúde pública. In: OLIVEIRA, J.E.P.; MILECH, A. (eds). Diabetes Mellitus: Clínica, Diagnóstico, Tratamento Multidisciplinar. São Paulo: Atheneu, p. 19-32, 2004.

FRANK, R.N. Diabetic Retinopathy. New England Journal of Medicine, 350: 48-58, 2004

GARCIA, V.D. Visão de cores, sensibilidade ao contraste e mfERG em indivíduos com Diabetes Mellitus tipo 1. 2004. 90 f. Dissertação (Mestrado em Psicologia)-Instituto de Psicologia, Universidade de São Paulo, São Paulo, 2012.

GARCÍA-RAMIREZ, M.; HERNADEZ, C.; SIMO, R. Expression of erythropoietin and its receptor in the human retina: a comparative study of diabetic and nondiabetic subjects. Diabetes Care, 31:1189-1194, 2008.

GARDNER, T.W.; ANTONETTI, D.A.; BARBER, A.J.; LANOUE, K.F.; LEVINSON, S. W.; THE PENN STATE RETINA RESEARCH GROUP. Diabetic Retinopathy: More Than Meets the Eye. Survey of Ophthalmology, 47, (2): S253-262, 2002.

GASTINGER, M.J.; SINGH, R.S.J.; BARBER, A.J. Loss of cholinergic and Dopaminergic Amacrine Cells in Streptozotocin-Diabetic Rat and Ins2Akita-Diabetic Mouse Retinas. Investigative Ophthalmology and Visual Science, 47: 3143-3150, 2006.

GENC, S.; KOROGLUB, T.F.; GENC, K. Erythropoietin and the nervous system. Brain Research, 1000: 19-31, 2004

GERALDES, P; HIRAOKA-YAMAMOTO, J.; MATSUMOTO, M.; CLERMONT, A.; LEITGES, M.; MARETTE, A.; AIELLO, L.P..; KERN, T.S.; KING, G.L. Activation of 
PKC-delta and SHP-1 by hyperglycemia causes vascular cell apoptosis and diabetic retinopathy. Nat Med, 15: 1298-1306, 2009.

GHOLAMHOSSEIN, Y.; BEHROUZ, H.; ASGHAR, Z. Diabetic Retinopathy Risk Factors: Plasma Erythropoietin as a Risk Factor for Proliferative Diabetic Retinopathy. Korean J Ophthalmol 28(5):373-378, 2014.

GREVE, E.L. Primary angle closure glaucoma: extracapsular cataract extraction or filtering procedure? Int Ophthalmol., 12(3):157-162, 1988.

GRIMM C.; WENZEL, A.; GROSZER, M. HIF-1-induced erythropoietin in the hypoxic retina protects against light-induced retinal degeneration. Nat Med, 8:718-24, 2002.

GUALTIERI, M. Visão de cores e sensibilidade ao contraste em indivíduos com diabetes melito: avaliação psicofísica e eletrofisiológica. 2004. 153 f. Dissertação (Mestrado em Psicologia)-Instituto de Psicologia, Universidade de São Paulo, São Paulo, 2004.

GUALTIERI, M. Avaliação funcional da visão de pacientes diabéticos em estados pré e pós retinopatia diabética. 2009. 139 f. Tese (Doutorado em Psicologia)-Instituto de Psicologia, Universidade de São Paulo, São Paulo, 2009.

HAMMES, H.P.; FEDEROFF, H.J.; BROWNLEE, M. Nerve growth factor prevents both neuroretinal programmed cell death and capillary pathology in experimental diabetes. Molecular Medicine 1, 527-534, 1995.

HARDY, K.J.; LIPTOM, J.; SCASE, M.O.; FOSTER, D.H.; SCARPELLO, J.H.B. Detection of color-vision abnormalities in uncomplicated type 1 diabetic-patients with angiographically normal retinas. British Journal of Ophthalmology, 76: 461-464, 1992.

HARRIS, A.; AREND, O.; DANIS, R.P.; EVANS, D.; WOLF, S.; MARTIN, B.J. Hyperoxia improves contrast sensitivity in early diabetic retinopathy. British Journal of Ophthalmology, 80: 209-213, 1996.

HASROD N.; RUBIN A. Colour vision: A review of the Cambridge Colour Test and other colour testing methods. Afr. Vision Eye Health, 74:1, art. 23, 2015. Disponível em:〈http://dx.doi.org/10.4102/aveh.v74i1.23〉. 
HISATOMI, O.; YAMAMOTO, S.; KOBAYASHI, Y.; HONKAWA, H.; TOKUNAGA, Y.T. Evolution of Visual Pigments and Related Molecules. Journal of Photoscience, 41: 43, 2002.

HERNANDEZ, M.; FONOLLOSA, A.; GARCIA-RAMIREZ, M.; HIGUERA, M.; CATALAN, R.; MIRALLES, A.; GARCIA-ARUMI, J.; SIMON, R. Erythropoietin Is Expressed in the Human Retina and It Is Highly Elevated in the Vitreous Fluid of Patients With Diabetic Macular Edema, Diabetes Care, Volume 29, N. 9: 2028-2033, 2006.

HOSSEINI, S.M.; BORIGHT, A.P.; SUN, L.; CANTY, A.J.; BULL, S.B.; KLEIN, B.E.K.K.; KLEIN, R.; THE DCCT/ EDIC RESEARCH GROUP; PATERSON, A.D. The association of previously reported polymorphisms for microvascular complications in a meta-analysis of diabetic retinopathy. Hum Genet, 134: 247-257, 2015.

HOOGENDOORN, B.; COLEMAN, S. L.; GUY, C. A.; SMITH, K.; BOWEN, T.; BUCKLAND, P. R.; O'DONOVAN M.C. Functional analysis of human promoter polymorphisms. Hum. Mol. Genet., vol. 12, n. 18, p. 2249-54, 2003.

IZUTA, H.; CHIKARAISHI, Y.; ADACHI, T.; SHIMAZAWA, M.; SUGIYAMA, T.; IKEDA, T.; HARA, H. Extracellular SOD and VEGF are increased in vitreous bodies from proliferative diabetic retinopathy patients. Molecular Vision, 15: 2663-2672, 2009.

JELKMANN, W. Erytropoietin: Structure, Control of Production, and Function. Physiol. Rev., 72: 449-489, 1992.

JELKMANN, W. Regulation of erythropoietin production. The Journal of Physiology, 589 (6):1251-1258, 2011.

KANKOVA, K.; STEJSKALOVÁ, A.; PACÁL, L.; TSCHOPLOVÁ, S.; HERTLOVÁ, M.; KRUSOVÁ; IZAKOVICOVÁ-HOLLA; BERÀNEK, M.; VASKU, A.; BARRAL, S.; OTTANKOVA, J. Genetic risk factors for diabetic nephropathy on chromosomes $6 p$ and 7q identified by the set-association approach. Diabetologia, 50:990-999, 2006.

KATSURA, Y.T.; OKANO, K.; MATSUNO. Erythropoietin is highly elevated in vitreous fluid of patients with proliferative diabetic retinopathy. Diabetes Care, 28(9): 2252-2254, 2005.

KECK, P.J.; HAUSER, S.D.; KRIVI, G.; SANZO, K.; WARREN, T.; FEDER, J.; CONNOLLY, D.T. Vascular permeability factor, an endothelial cell mitogen related to PDGF. Science, 246:1309-12, 1989. 
KERN, T.S.; BERKOWITZ, B.A. Photoreceptors in diabetic retinopathy. J.Diabetes Invest, 6: 371-380, 2015.

KERN, T.S. Interrelationships between the Retinal Neuroglia and Vasculature in Diabetes. Diabetes Metab J, 38(3), pp. 163-70, Jun, 2014.

ö, H. Die Störungen des Farbensinners. ihre klinische Bedeutung und ihre Diagnose. Berlin: Karger; 1912. APUD; SCHWARTZ, S. Visual Perception: A Clinical Orientation. New York, New York; 2010.

KOWLURU, R.A.; MISHRA, M. Oxidative Stress, Mitochondrial Damage and Diabetic Retinopathy. BBA-Molecular Basis of Disease, 2015. Disponível em: <doi: 10.1016/j.bbadis.2015.08.001>.

KURTENBACH, A.; WAGNER, U.; NEU, A.; SCHIEFER, U.; RANKE, M.B.; ZRENNER, E. Brightness Matching and Color Discrimination in Young Diabetics without Retinopathy. Vision Research, 34: 115-122, 1994.

LI, Y.; NOWOTNY, P.;HOLMANS, P. Association of late-onset Alzheimer's disease with genetic variation in multiple members of the GAPD gene family. Proc Nat. Ac.Sci USA, 101 (44): 15688-15693, 2004.

LIU, J.; SHI, B.; HE, S.; YAO, X.: WILLCOX, M.D.P.; ZHAO, Z. Changes to tear cytokines of type 2 diabetic patients with or without retinopathy. Molecular Vision, 16: 2931-2938, 2010.

LIVINGSTONE, M.; HUBEL, D. Anatomy and physiology of a color system in the primate visual cortex. Journal of Neuroscience, 4: 309-356, 1984.

LIN, P.I.; VANCE, J.M.; PERICAK-VANCE, M.A.; MARTIN, E.R. No gene is an island: the flipflop phenomenon. Am J Hum Genet. 80(3): 531-538, 2007.

MAIESE, K.; LI, F; CHONG, Z.Z. New Avenues of Exploration for Erythropoietina. JAMA, 5: 293 (1): 90-95, Janeiro, 2005. 
MIOT, H.A. Tamanho da amostra em estudos clínicos e experimentais, J. Vasc. Bras., vol. 10, 4: 275-278, 2011.

MIYAMOTO, K.; OGURA, Y. Pathogenetic potential of leukocytes in diabetic retinopathy. Semin Ophthalmol .14: 233-239, 1999.

MOEMEN, L.A.; HAMID, M.A.A.; KHALEF, N.A.; ELSERGANY, T. M.; KLHEF, M.A. Association between Erythropoietin Gene Polymorphisms and Diabetic Retinopathy. Journal of Applied Sciences Research, Vol. 9 (4): 3032-3036, 2013.

MOHAN, N.; MONICKARAJ, F.; BALASUBRAMANYAM, M.; REMA, M.; MOHAN, V. Imbalanced levels of angiogenic and angiostatic factors in vitreous, plasma and postmortem retinal tissue of patients with proliferative diabetic retinopathy. Journal of Diabetes and Its Complications, 26: 435-441, 2012.

MOLlON, J. D.; REGAN, B. C. Cambridge Colour Test: Handbook. Version 1.1. January 2000.

PALMOWSKI, A.M.; SUTTER, E.E.; BEARSE, M.A.; FUNG, W. Mapping of retinal function in diabetic retinopathy using the multifocal electroretinogram. Investigative Ophthalmology and Visual Science, 38: 2586-2596, 1997.

POKORNY, J.; SMITH, V.C.; JOHNSTON, P. (Eds) Congenital and Acquired Color Vision Defects. New York: Grune \& Stratton, 1979.

RIBEIRO, I.F. Avaliação das interações entre a suplementação antioxidante com o óleo de pequi (Caryocar brasiliense Camb.) e os polimorfismos nos genes da $\alpha$ - actinina-3 (ACTN-3), eritropoetina (EPO) e seu receptor (EPOR) nos resultados do hemograma, marcadores bioquímicos e peroxidação lipídica, em corredores de rua. 2013. 100f. Dissertação (Mestrado em Patologia Molecular)-Faculdade de Medicina, Universidade de Brasília, Distrito Federal, 2013.

ROCKETT, M.; ANDERLE, D.; BESSMAN. A.N. Blue-Yellow Vision Deficits in Patients with Diabetes. West J Med, 146: 431-433, 1987.

RUSHTON, W.A.H. A Cone Pigment in the Protanope. J. Physiol., 168: 345-359, 1963. 
SCHWARTZ, S.H. Visual Perception: A Clinical Orientation. Nova York: McGraw Hill Medical, Fouth Edition, 2010.

SCOTT, T.M.; FOOTE, J.; PEAT, B.; GALWAY, G. Vascular and neural changes in the rat optic nerve following inductionof diabetes with streptozotocin. Journal Anat, 144:145-152, 1986.

SENGER, D.R.; GALLI, S.J.; DVORAK, A.M.; PERRUZZI, C.A.; HARVEY, V.S.; DVORAK, H.F. Tumor cells secrete a vascular permeability factor that promotes accumulation of ascites fluid. Science, 219:983-985, 1983.

SHARMA, Y., SAXENA, S., MISHRA, A., SAXENA, A., NATU, S.M. Advanced glycation end products and diabetic retinopathy. J. Ocul. Biol. Dis. Inform., 5: 63-69, 2012.

SHEETZ, M. J.; KING, G.L. Molecular Understanding of Hyperglycemia's Adverse Effects for Diabetic Complications, JAMA, 288 (20), pp. 2579-2588, 2002.

SHEN, W.; CHUNG, S.H.; IRHIMEH, M.R.; LI, S.; LEE, S-R. Systemic Administration of Erythropoietin Inhibits Retinopathy in RCS Rats. PLoS ONE, 9:(8), 2014.

SOBRIN, L. ET AL. Candidate Gene Association Study for Diabetic Retinopathy in Persons with Type 2 Diabetes: The Candidate Gene Association Resource (CARe). IOVS, 52: 10, 2011.

SOCIEDADE BRASILEIRA DE DIABETES. São 12 milhões de diabéticos no Brasil. 2012. Disponível em: < http://www.diabetes.org.br/sala-de-noticias/2116-sao-12milhoes-de-diabeticos-no-brasil/format=pdf> Acesso em: 15/09/2012.

SOCIEDADE BRASILEIRA DE DIABETES. Diretrizes da Sociedade Barsileira de Diabetes: 2014-2015. [Org: José Egídio Paulo de Oliveira; Sérgio Vencio. São Paulo: AC Farmacêutica, 2015. 
SOCIEDADE BRASILEIRA DE PATOLOGIA CLÍNICA. Recomendações da Sociedade Brasileira de Patologia Clínica/ Medicina Laboratorial para coleta de sangue venoso. Segunda Edição, Barueri, São Paulo: Editora Manole, 2010.

SONG, Q.; ZHANG, Y.; WU, Y.; ZHOU, F.; QU, Y. Association of erythropoietin gene polymorphisms with retinopathy in a Chinese cohort with type 2 diabetes mellitus. Clinical and Experimental Ophthalmology , 43: 544-549, 2015.

SOUZA, N.V.; RODRIGUES, M.L.V. Manifestações Oculares de Doenças Sistêmicas. Medicina, Ribeirão Preto, vol. 30: pp. 79-83, Jan/Mar, 1997.

STEVENS, R.J.; KOTHARI, V.; ADLER, A.I.; STRATON, I.M.; HOLMAN, R.I. On behalf of the United Kingdom Prospective Diabetes Study (UKPDS) Group. The UKPDS risk engine: A model for the risk of coronary heart disease in type II diabetes (UKPDS 56). Clinical Science: 101: 671-679, 2001.

STITT,A.W.; CURTIS,T.M.; CHEN, M.; MEDINA, R.J.; MCKAY, G.J.; JENKINS, A.; GARDINER, T.A.; LYONS, T. J.; HAMMES, H.P.; SIMO, R.; LOIS, N. 2015 The progress in understanding and treatment of diabetic retinopathy. Progress in Retinal and Eye Research XXX: 1-30, 2015.

THE PKC-DRS2 GROUP. Effect of ruboxistaurin on visual loss in patients with diabetic retinopathy. Ophthalmology 113: 2221-30, 2006.

THORSEN, S.U.; SANDAHL, K.; NIELSEN, L.B., BROE, R.; RASMUSSEN, M.L.; PETO, T.; GRASLUND, J.; ANDERSEN, M.L.M.; MORTENSEN, H.B.; POCIOT, F.; OLSEN, B.S.; BRORSSON, C. Polymorphisms in the CTSH gene may influence the progression of diabetic retinopathy: a candidate-gene study in the Danish Cohort of pediatric Diabetes 1987 (DCPD1987), Graefes Arch Clin Exp Ophthalmol, 253(11):195965, Nov, 2015.

TONG, Z.; YANG, Z.; PATEL, S.; CHEN, H.; GIBBS, D.; YANG, X.; HAU, V.S.; KAMINOH, Y.; HARMON, J.; PEARSON, E.; BUEHLER, J.; CHEN, Y.; YU, B.; TINKHAM, N.H.; ZABRISKIE, N.A.; ZENG, J.; LUO, L.; SUN, J.K.; PRAKASH, M.; HAMAM, R.N.; TONNA, S.; CONSTANTINE, R.; RONQUILLO, C.C.; SADDA, S.; AVERY, R.L.; BRAND, J.M.; LONDON, N.; ANDUZE, A.L.; KING, G.L.; BERNSTEIN, P.S.; WATKINS, S.; GENETICS OF DIABETES AND DIABETIC COMPLICATION STUDY GROUP; JORDE, L.B.; LI, D.Y.; AIELLO, L.P.; POLLAK, M.R.; ZHANG, K. Promoter polymorphism of the erythropoietin gene in severe diabetic eye and kidney complications. Proc Natl Acad Sci USA.13;105(19):6998-7003, 2008. 
TOVÈE, M. J. An Introduction to the Visual System. Nova York: Cambridge University Press, 2008.

TSAI, J.C. DENNISTOR, A.K.O.; MURRAY, P.I.; HANG, J.J.; ALDAD, T.S. Oxford American Handbook of Ophthalmology. Nova York: Oxford University Press, 2011.

VENTURA, D.F.; NISHI, M.; BERNICK, M.; COSTA, M.F.; BONCI, D.M.O.; GUALTIERI, M.; SOUZA, J.M. Early vision loss in diabetic patients assessed by the Cambridge Colour Vision Test. In: MOLLON, J.D.; POKORNY, J.; KNOBLAUCH, K. (Editors) Normal and Defective Colour Vision. Oxford University Press, pp.395-403, 2003.

WAN, T.T.; LI, X.F.; SUN, Y.M.; LI, Y.B.; SU, Y. Recent advances in understanding the biochemical and molecular mechanism of diabetic retinopath. Biomedicine \& Pharmacotherapy, 74: 145-147, 2015.

WANG, Y.D.; WU, J.D.; JIANG, Z.L.; WANG, Y.B.; WANG, X.H.; CHAO, L; TONG, M.Q. Comparative Proteome Analysis of Neural Retinas from Type 2 Diabetics Rats by Two-dimensional Electrophoresis. Current Eye Research, 32: 891-901, 1993.

WATANABE, D.K.; SUZUMA, S.; MATSUI, S.; KURIMOTO, M.; KIRYU, J.; KITA, M.; SUZUMA, I.; OHASHI, H.; OJIMA, T,; MURAKAMI, T.; KOBAYASHI, T.; MASUDA, S.; NAGAO, M.; YOSHIMURA, S.; TAKAGI, H. Erythropoietin as a retinal angiogenic factor in proliferative diabetic retinopathy. $N$. Eng J Med, 353 (8): 782-792, 2005.

WILD, S.; ROGLIC, G.; GREEN, A.; SICREE, R.; KING, H. Global Prevalence of Diabetes Estimates for the Year 2000 and Projections for 2030. Diabetes Care, 27: 10471053, 2004.

WORLD HEALTH ORGANIZATION (WHO). Definition, Diagnosis and Classification of Diabetes Mellitus and its Complications: Report of a Who Consultation, Part 1: Diagnosis and Classification of Diabetes Mellitus. Geneva, World Health Org, 2006.

YAMAJI, R.T.; OKADA, M.; MORIYA. Brain capillary endothelial cells express two forms of erythropoietin receptor mRNA. Eur J. Biochem, 239 (2): 494-500, 1996. 
YANG, X.; DENG, Y.; GU, H.; REN, X.; Li, N.; LIM, A.; SNELLINGEN, T.; LIU, X.; WANG, N.; LIU, N. Candidate gene association study for diabetic retinopathy in Chinese patients with type 2 diabetes. Molecular Vision, 20: 200-214, 2014.

ZHANG, J.; WU, Y; JIN, Y.; JI, F.; SINCLAIR, S.H.; LUO, Y.; XU, G.; LU, L.; DAI, W.; YANOFF, M.: Intravitreal injection of erythropoietin protects both retinal vascular and neuronal cells in early diabetes. Invest Ophthalmol Vis Sci, 49: 732-742, 2008.

ZONG, H.; WARD, M.; STITT, A.W. AGEs, RAGE and diabetic retinopathy. Curr Diab. Rep., 11: 244-252, 2011. 


\section{ANEXOS-}

Anexo A- Aprovações do Comitê de Ética em Pesquisa com Seres Humanos.

Anexo B- Termo de Consentimento Livre e Esclarecido e Ficha de Anamnese.

Anexo C- Dados Brutos dos participantes com DM.

Anexo D- Dados Brutos dos participantes Controles. 
ANEXO A-

\section{INSTITUTO DE PSICOLOGIA Platoforma DA UNIVERSIDADE DE SÃO}

\section{PARECER CONSUBSTANCIADO DO CEP}

\section{DADOS DO PROJETO DE PESQUISA}

Título da Pesquisa: Associação entre genótipo de risco para Retinopatia Diabética Proliferativa e disfunçäo visual precoce

Pesquisador: Livia Soledade de Moraes Rego

Area Temática: Genética Humana:

(Trata-se de pesquisa envolvendo Genética Humana que näo necessita de análise ética por parte da CONEP;):

Versão: 2

CAAE: 25275613.1 .0000 .5561

Instituição Proponente:UNIVERSIDADE DE SAO PAULO

Patrocinador Principal: FUNDACAO DE AMPARO A PESQUISA DO ESTADO DE SAO PAULO

MINISTERIO DA EDUCACAO

MINISTERIO DA CIENCIA, TECNOLOGIA E INOVACAO

\section{DADOS DO PARECER}

Número do Parecer: 615.984

Data da Relatoria: $14 / 04 / 2014$

Apresentação do Projeto:

Projeto de mestrado, é uma pesquisa envolvendo Genética Humana, tem apoio financeiro da FUNDACAO DE AMPARO A PESQUISA, DO ESTADO DE SAO PAULO, MINISTERIO DA EDUCACAO E MINISTERIO DA CIENCIA, TECNOLOGIA E INOVACAO custo da pesquisa R\$20.000,56. A Retinopatia Diabética (RD) é a complicaçäo mais comum do Diabetes Mellitus (DM) e uma das principais causas mundiais de cegueira em adultos, com alguns trabalhos indicando incidência em $50 \%$ dos pacientes com 15 anos de diagnóstico de diabetes. $O$ presente projeto busca verificar a associação entre determinados genótipos apontados como sendo de risco para o desenvolvimento da RD e lesões da função neural, verificadas através de alterações na visão de cores, em pacientes com Diabetes Mellitus Tipo 2. Número de participantes 100; divididos da seguinte forma: Grupo Controle 40; Diabéticos com Retinopatia Diabética (DMCRD) 30 e Diabéticos sem Retinopatia Diabética (DMSRD) 30 .

Critério de Inclusäo:

Para participação no grupo experimental de Diabéticos sem RD: concordância com o Termo de

Consentimento Livre e Esclarecido apresentado; auséncia de opacidade dos meios ópticos;ausência

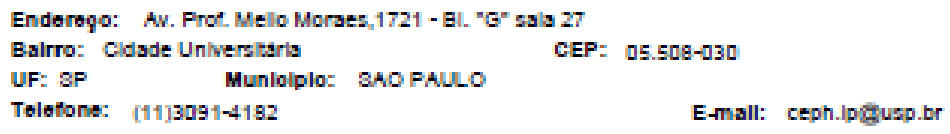


Plotonforma MINISTÉRIO DA SAÚDE - Conselho Nacional de Saúde - Comissão Nacional de Ética em Pesquisa - CONEP FOLHA DE ROSTO PARA PESQUISA ENVOLVENDO SERES HUMANOS

1. Projeto de Pesquisa: Associação entre genótipo de risco para Retinopatia Diabética Proliferativa e disfunção visual
precoce

3. Área Temática:

Genética Humana:

(Trata-se de pesquisa envolvendo Genética Humana que não necessita de análise ética por parte da CONEP;)

4. Área do Conhecimento:

Grande Área 4. Ciências da Saúde

\section{PESQUISADOR RESPONSÁVEL}

5. Nome:

Livia Soledade de Moraes Rego

6. CPF:

$315.268 .728-11$

8. Nacionalidade:

BRASILEIRO

12. Cargo:

(Rua, n. ):

\begin{tabular}{|l|l|l}
$\begin{array}{l}\text { 9. Telefone: } \\
\text { (11) 3091-1914 }\end{array}$ & 10. Outro Telefone: & $\begin{array}{l}\text { 11. Email: } \\
\text { livia.rego@usp.br }\end{array}$ \\
\hline
\end{tabular}

2. Número de Participantes da Pesquisa: 100

Termo de Compromisso: Declaro que conheço e cumprirei os requisitos da Resolução CNS 466/12 e suas complementares. Comprometo-me a

Aceito as responsabilidades pela colados exclusivamente para os fins previstos no protocolo e a publicar os resultados sejam eles favoráveis ou não.

Aceito as responsabilidades pela condução científica do projeto acima. Tenho ciência que essa folha será anexada ao projeto devidamente assinada

por todos os responsáveis e fará parte integrante da documentação do mesmo.

05508030 MELLO DE MORAIS, 1235 BUTANTA Bloco D, apto 305 SAO PAULO SAO PAULO
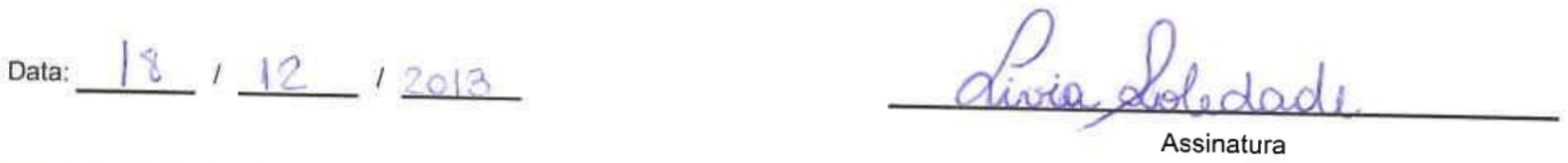

\section{INSTITUIÇÃO PROPONENTE}

\begin{tabular}{l|l|l|}
\hline $\begin{array}{l}\text { 13. Nome: } \\
\text { UNIVERSIDADE DE SAO PAULO }\end{array}$ & $\begin{array}{l}\text { 14. CNPJ: } \\
63.025 .530 / 0010-03\end{array}$ & $\begin{array}{l}\text { 15. Unidade/Órgão: } \\
\text { UNIVERSIDADE DE SAO PAULO }\end{array}$ \\
\hline 16. Telefone: & 17. Outro Telefone:
\end{tabular}

Termo de Compromisso (do responsável pela instituição): Declaro que conheço e cumprirei os requisitos da Resoluçäo CNS $466 / 12$ e suas

Complementares e como esta instituição tem condiçōes para o desenvolvimento deste projeto, autorizo sua execução.

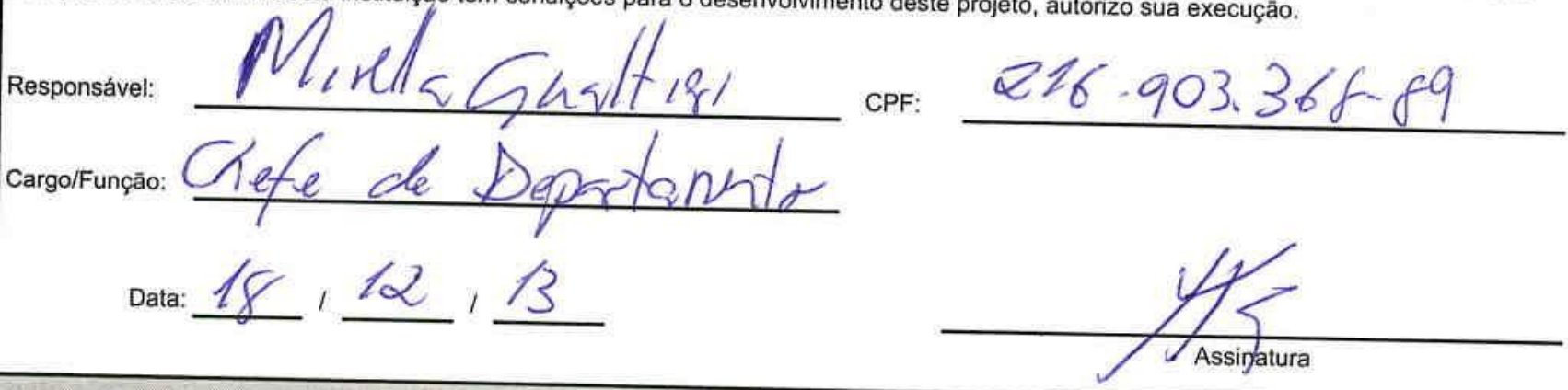


18. Nome:

19. Telefone:

20. Outro Telefone:

5560 FUNDACAO DE AMPARO A PESQUISA DO ESTADO

DE SAO PAULO

Termo de Compromisso: Declaro que conheço e cumprirei os requisitos da Resolução CNS 466/12 e suas complementares. Comprometo-me a

utilizar os materiais e dados coletados exclusivamente para os fins previstos no protocolo e a publicar os resultados sejam eles favoráveis ou não.
Aceito as responsabilidades pela condução cientifica do projeto acima.

Nome:

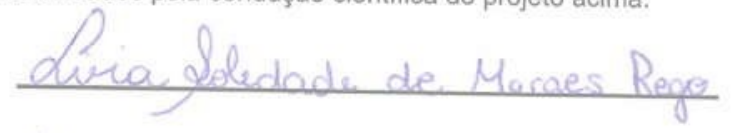

CPF:

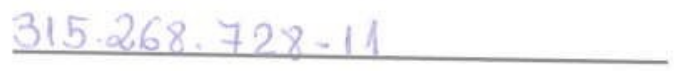

Cargo/Função:

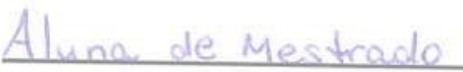

Email:

Data: $18,12,2013$

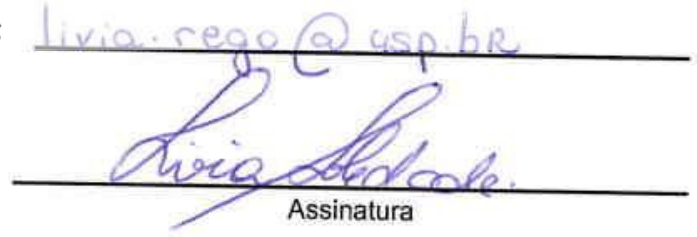


ANEXO B-

Universidade de São Paulo

Instituto de Psicologia

Departamento de Psicologia Experimental

Setor de Eletrofisiologia e Psicofísica Visual Clínica

\section{TERMO DE CONSENTIMENTO LIVRE E ESCLARECIDO}

\section{ASSOCIAÇÃO ENTRE GENÓTIPO DE RISCO PARA RETINOPATIA DIABÉTICA PROLIFERATIVA E DISFUNÇÃO VISUAL PRECOCE}

Pesquisadores: Livia Soledade de Moraes Rego, Mariana Fernandes Yamamoto, Valéria Duarte Garcia, Liga de Controle do Diabetes do Hospital das Clínicas da Faculdade de Medicina da Universidade de São Paulo, Profa Dra Daniela M. O. Bonci,

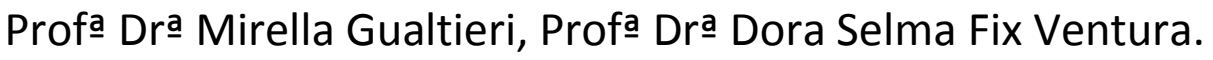

Você está sendo convidado(a) a participar de uma pesquisa que tem como objetivo identificar possíveis predisposições genéticas ao desenvolvimento da retinopatia diabética. Em primeiro lugar, você passará por um exame computadorizado de visão de cores. Depois, faremos a coleta de uma pequena amostra de sangue $(3 \mathrm{ml})$, realizada por enfermeira graduada e habilitada. Nós cuidaremos para que todos os procedimentos de segurança e higiene sejam cuidadosamente efetuados. A amostra de sangue será totalmente utilizada (não haverá descarte de sangue), para extração e análise de DNA. Os riscos que envolvem a coleta de sangue venoso (das veias) são: formação de hematoma local, punção acidental de artéria, infecção, dor e lesão de nervo próximo ao local de punção. Seu nome ou qualquer outra informação que possam identificá-lo não serão revelados publicamente.

Você poderá deixar de participar desta pesquisa a qualquer momento se assim o desejar, sem que isso acarrete qualquer prejuízo. Também terá acesso a qualquer momento às informações de

Sua participação não será remunerada e é totalmente voluntária. Este termo deverá ser impresso e assinado em duas vias: uma ficará com você e a outra será anexada ao projeto, como comprovação documental. Nos casos de dúvidas estaremos disponíveis nos telefones abaixo:

- Livia Soledade de Moraes Rego: (11) 97485-9671. E-mail: livia.rego@usp.br;

- Profa. Dra. Mirella Gualtieri (Orientadora do Projeto): (11) 3091-8611. E-mail: mirellag@usp.br

- Silvia A. Sochiarelli (CEP-IP-USP): (11) 3091-4182. E-mail: ceph.ip@usp.br; 
Após ter lido as informações acima (ou alguém ter lido para você):

Estou ciente de todos os procedimentos a que serei submetido e autorizo a utilização de meus resultados para a pesquisa.

\section{Termo de Consentimento Pós-Esclarecido}

Nome:

№ de Identidade:

Sexo: ( ) F ( ) M

Data de Nascimento:

Endereço:

Telefone:

Eu,.....

Declaro que, após convenientemente esclarecido pelo pesquisador e ter entendido o que me foi explicado, consinto em participar do presente Projeto de Pesquisa.

São Paulo, ..... de de $201 \ldots$

Assinatura da participante da pesquisa

Livia Soledade de Moraes Rego Pesquisadora
Prof ${ }^{a}$ Draairella Gualtieri

Orientadora - IP -USP 
Universidade de São Paulo

Instituto de Psicologia

Departamento de Psicologia Experimental

Setor de Psicofísica e Eletrofisiologia Visual Clínica
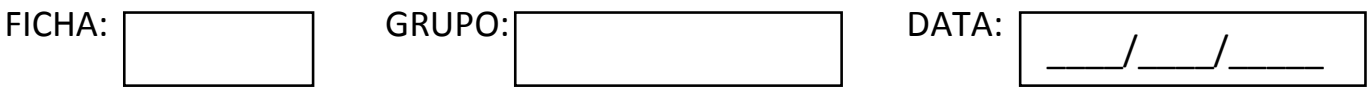

DADOS PESSOAIS:

NOME:

IDADE: ANOS

DATA DE NASCIMENTO:

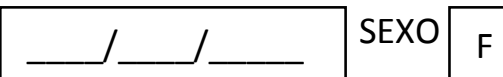

M

ENCAMINHAMENTO

ENDEREÇO:

BAIRRO:

CIDADE:

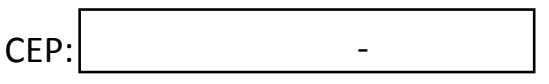

TELEFONE: $(1)$

CEL.: $(1)$

PROFISSÃO:

PROFISSÃO ANTERIOR:

EMAIL:

AVALIAÇÃO INICIAL

AV
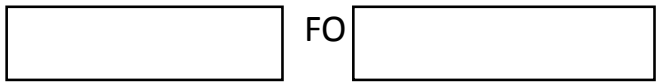

BIO

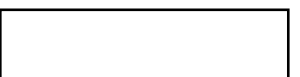

$\mathrm{RX}$
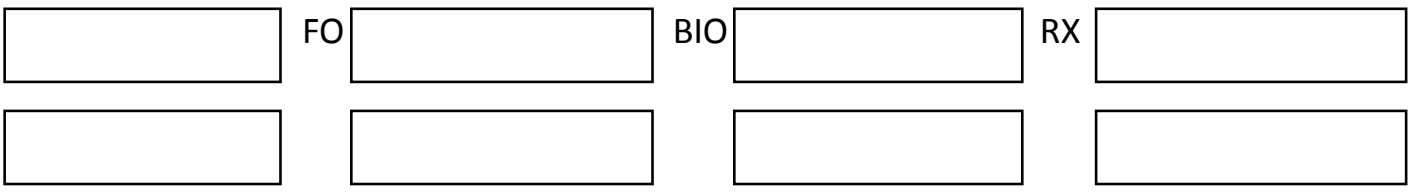

HISTÓRICO DE SAÚDE

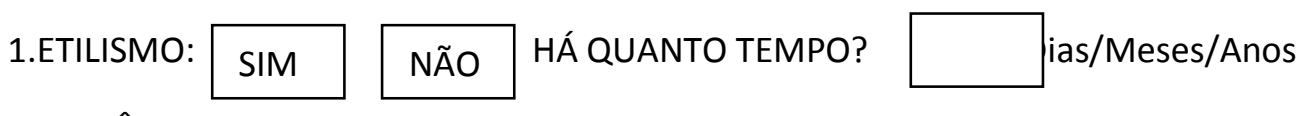

FREQUÊNCIA:
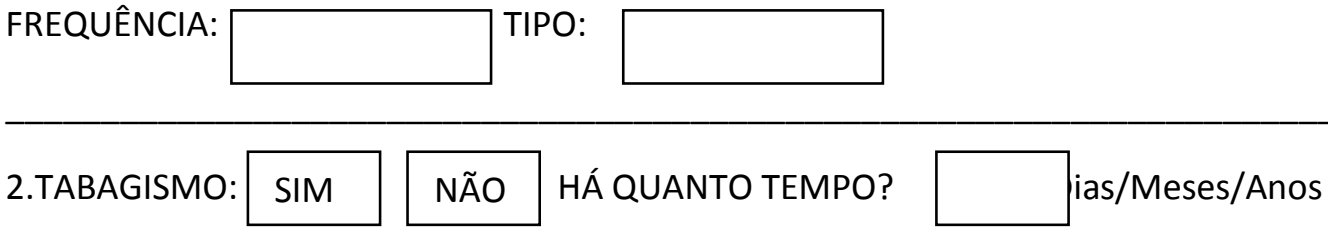

FREQUÊNCIA:

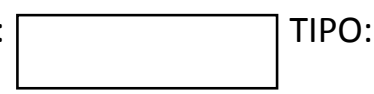

3. DIABETTES:

TIPO:

HÁ

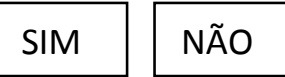



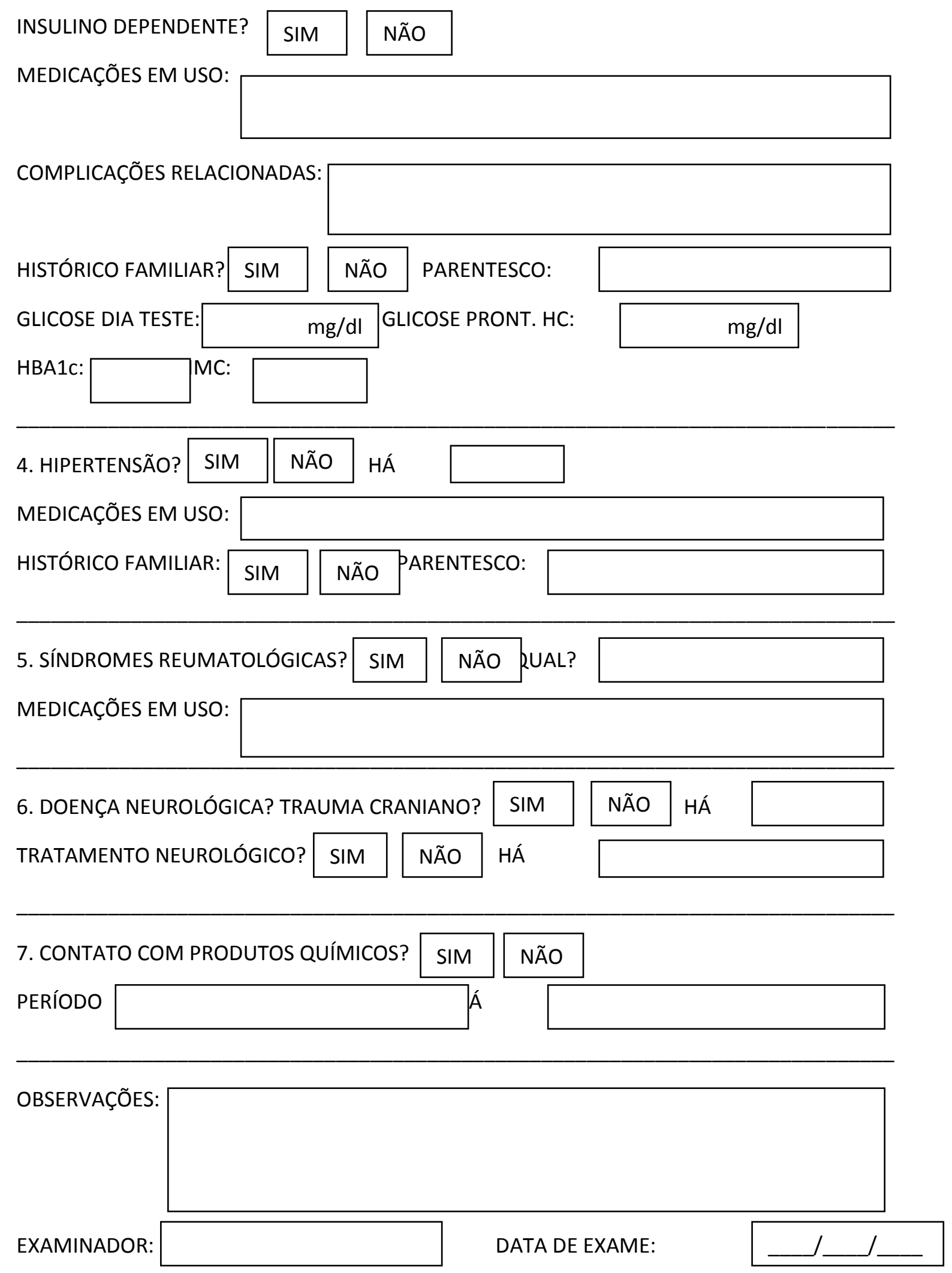
ANEXO C-

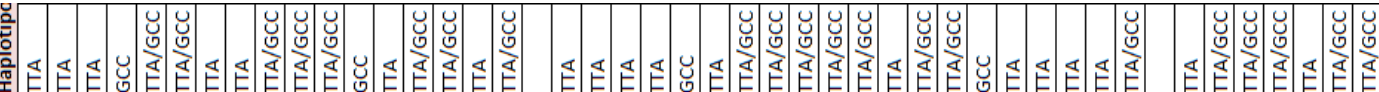

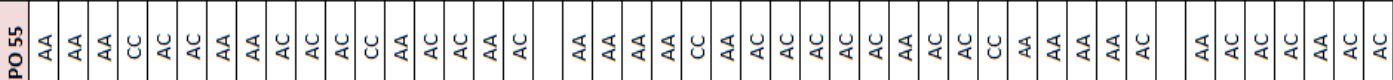

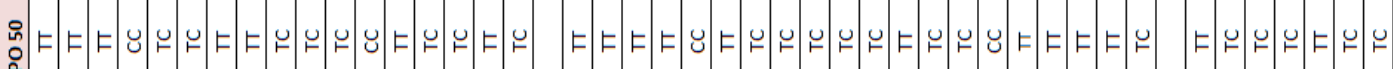

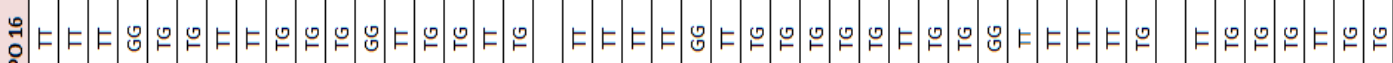

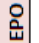

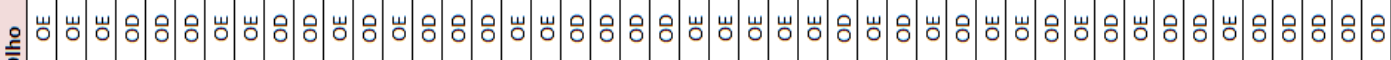

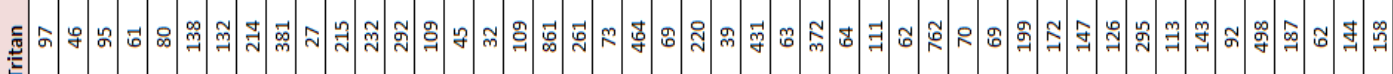

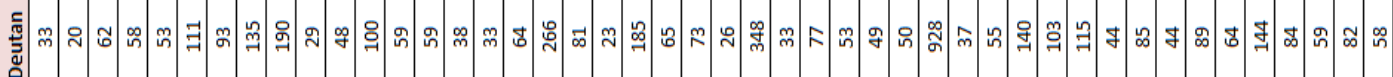

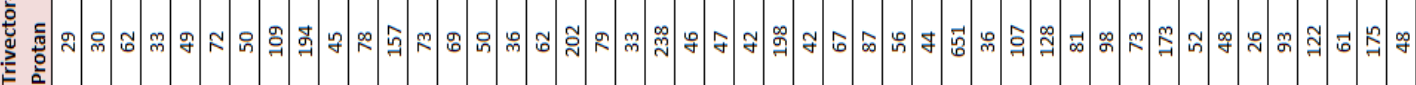

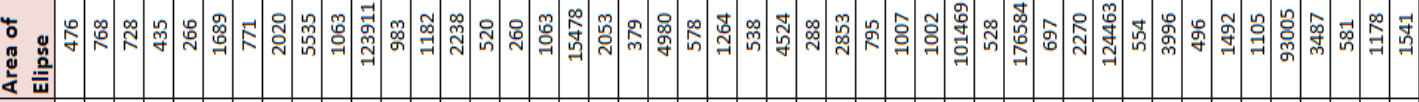

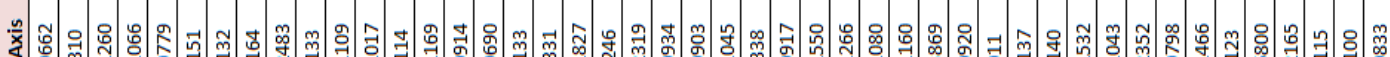

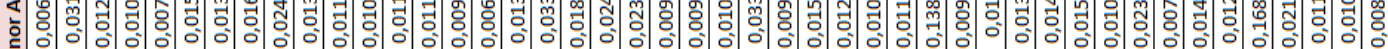

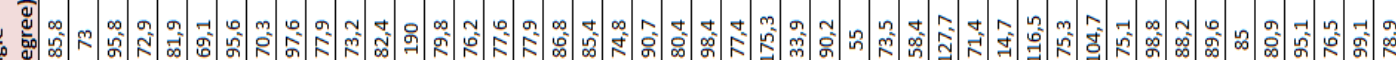
等

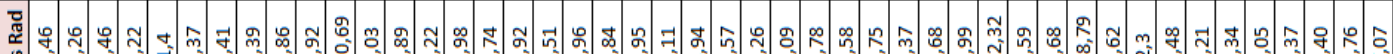

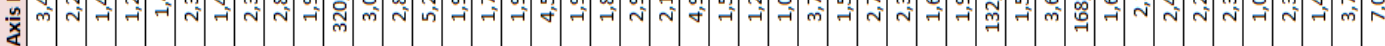

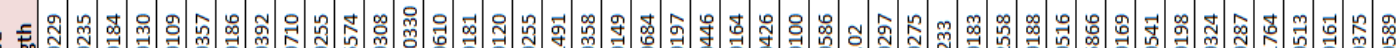

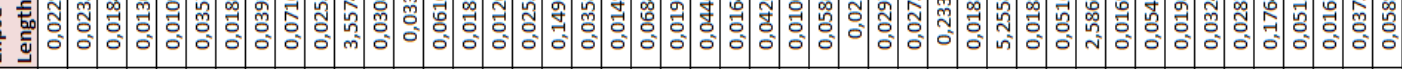

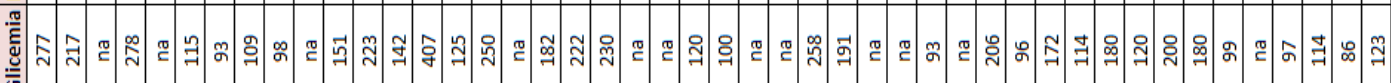
II

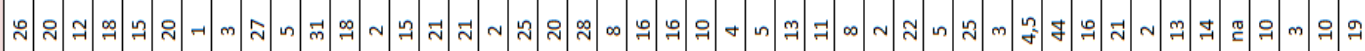

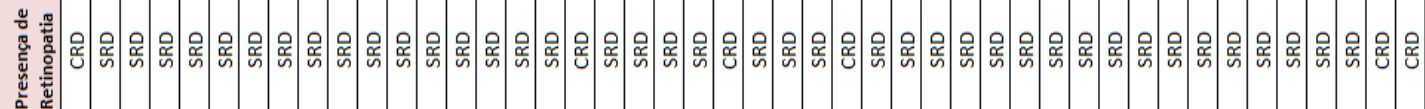

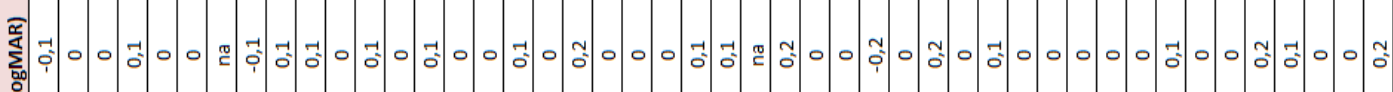
«의

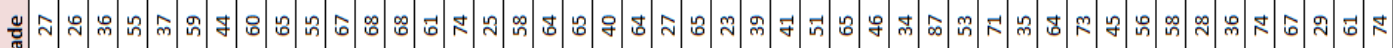

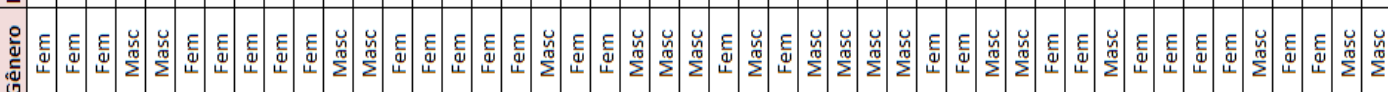

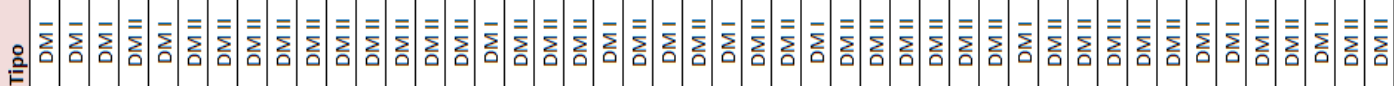

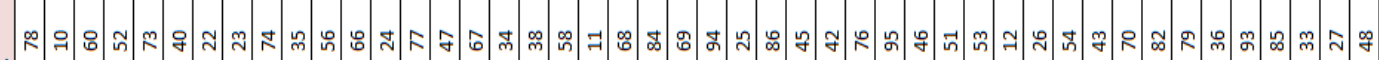




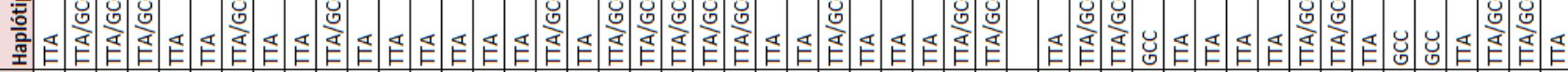

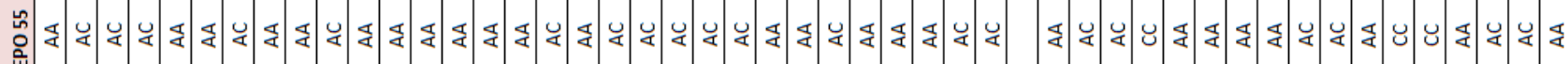

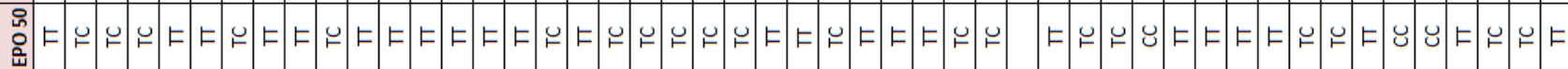

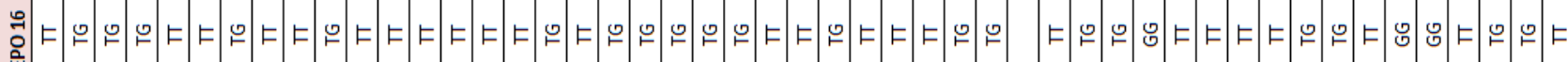

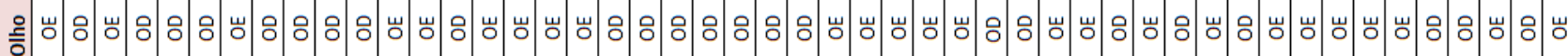

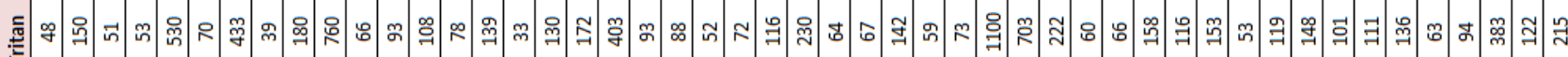

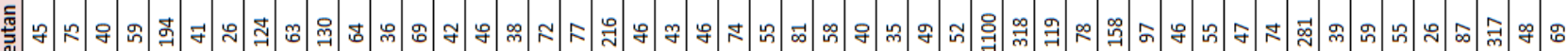

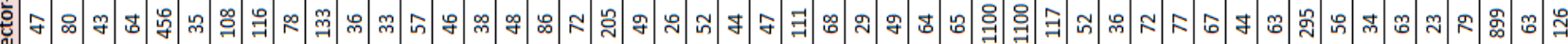
$\ddot{\circ}$ 造

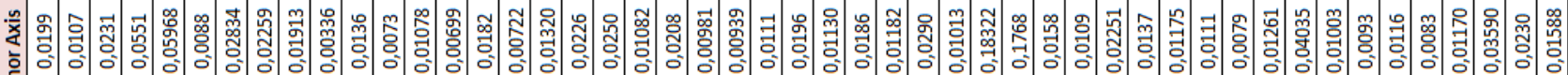

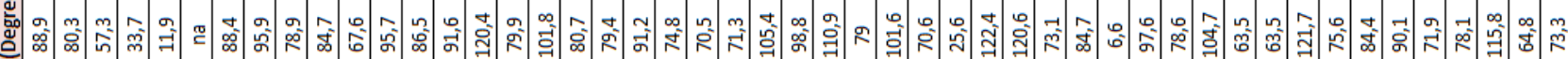
$\frac{20}{4}$

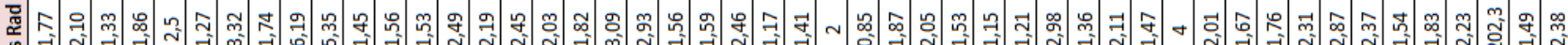

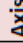

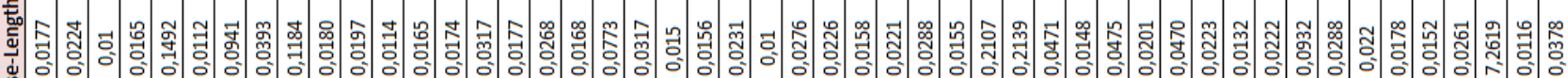

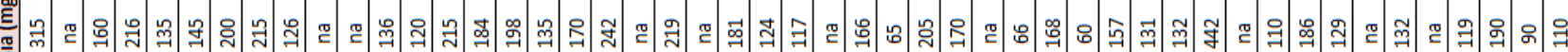
$\frac{\mathrm{E}}{\overline{0}}$

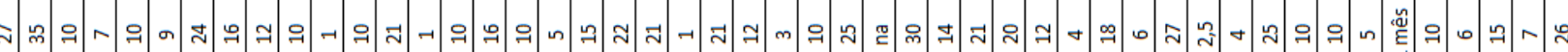

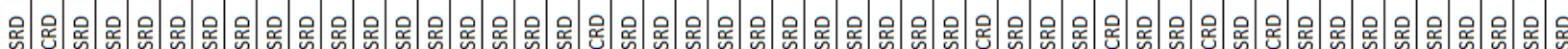
离

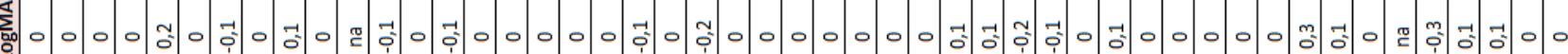
खे

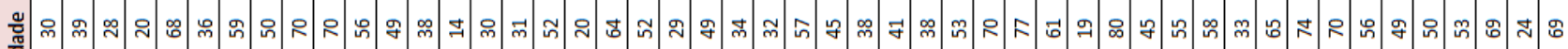

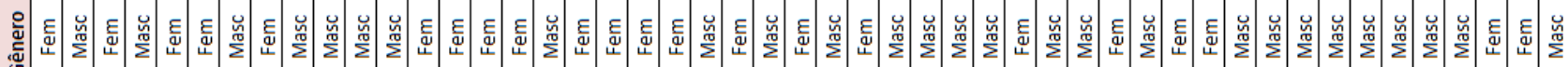

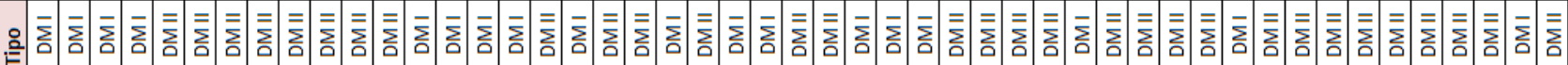

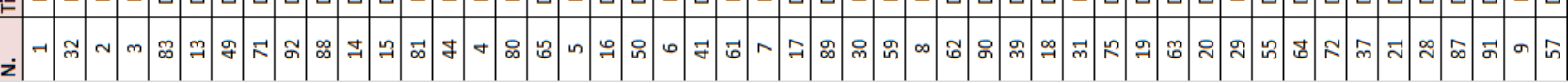


ANEXO D-

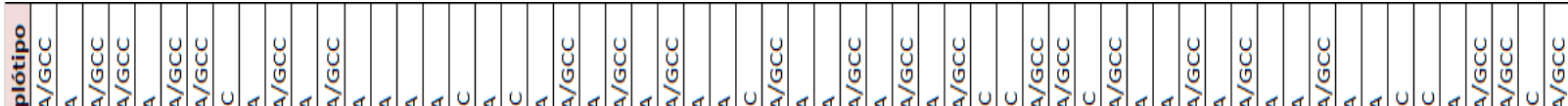

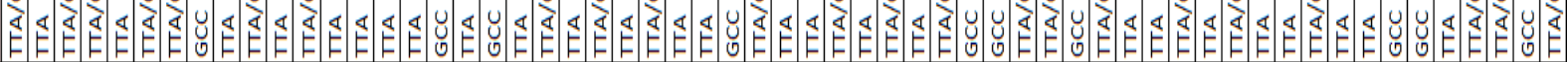
:

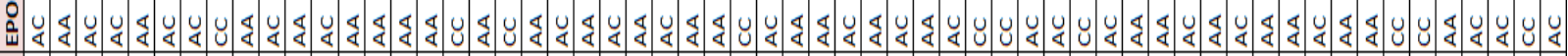
i

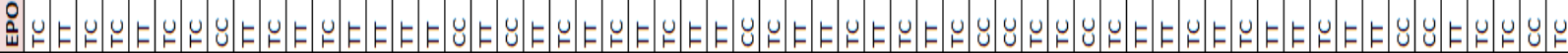

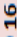

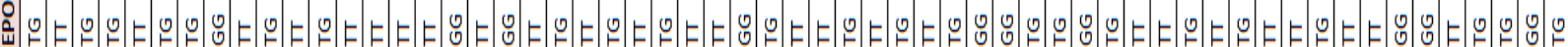

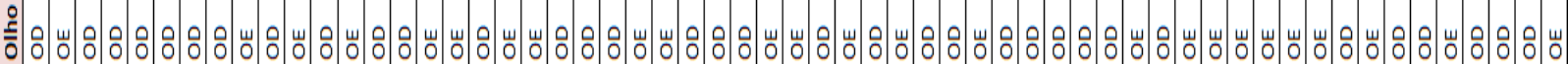

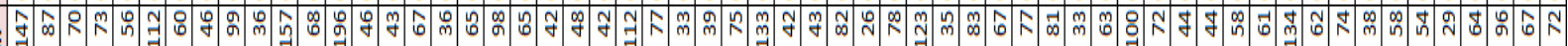
要

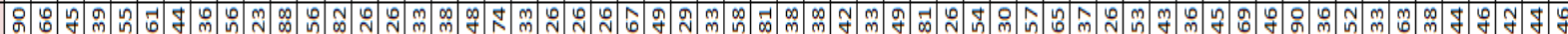

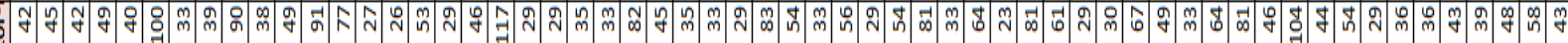

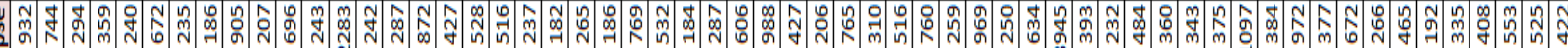

$\frac{2}{4}$

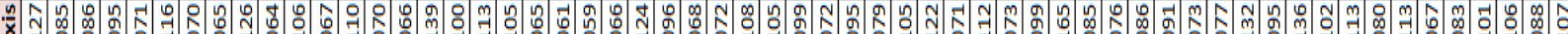

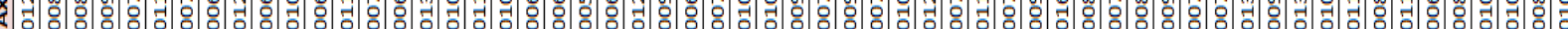
60 -

क ซृ

$\frac{n}{\mathrm{x}}$

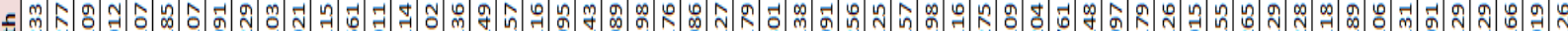
ร

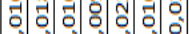
० की

㟧

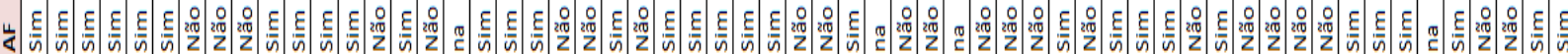

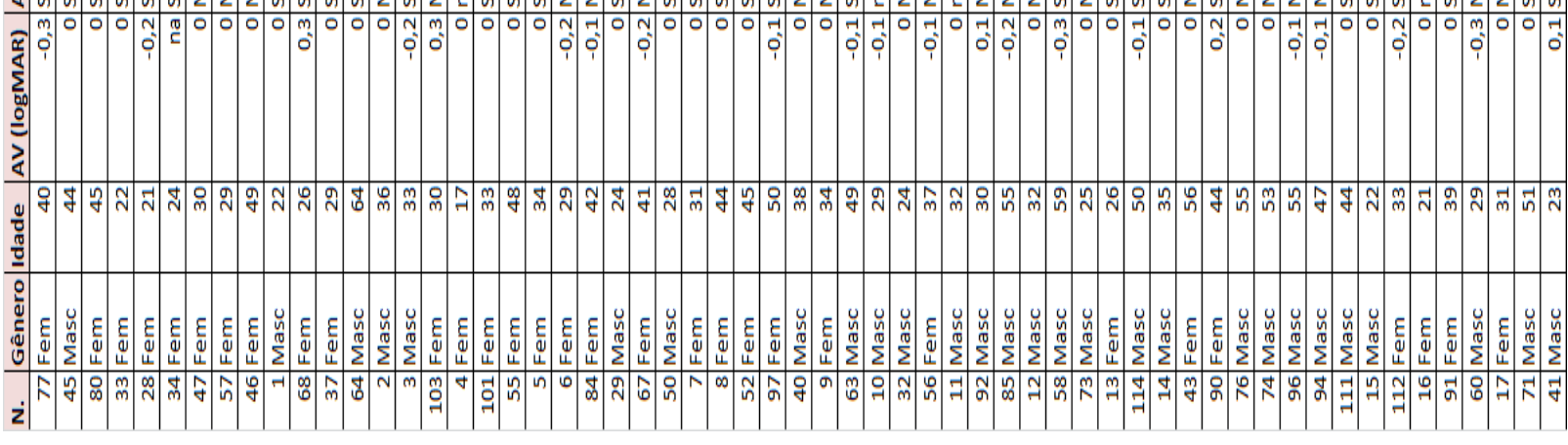


:

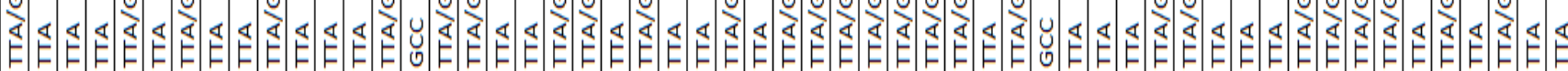
足

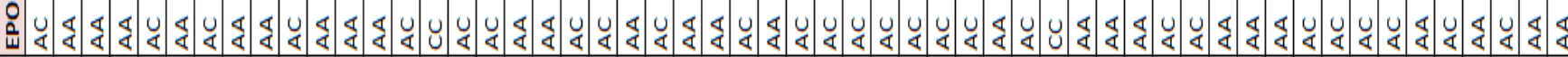

讨

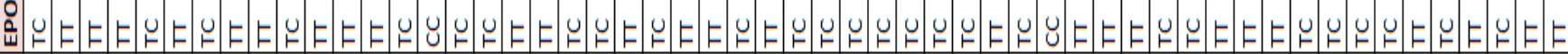

象

ش

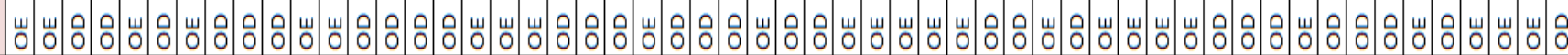
N

$\stackrel{5}{\mathrm{~m}}$

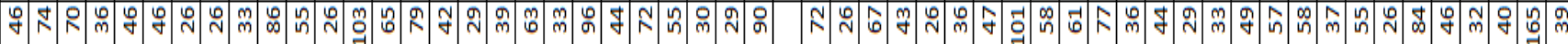

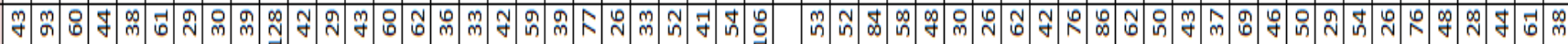

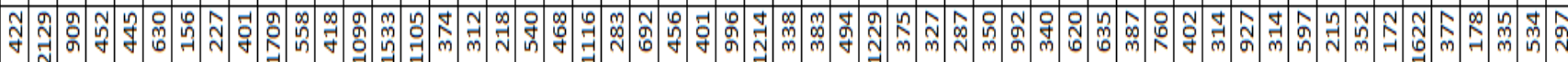

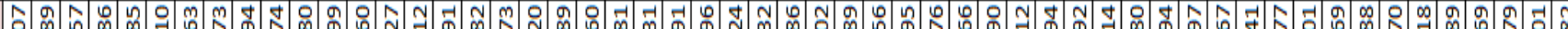

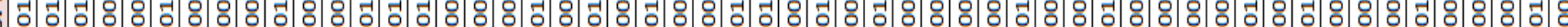

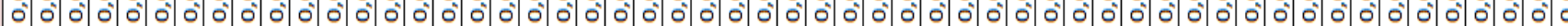

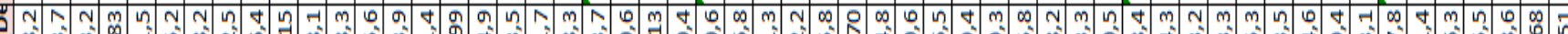

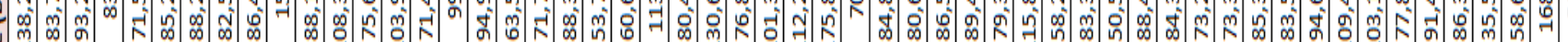

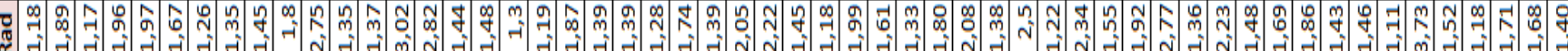

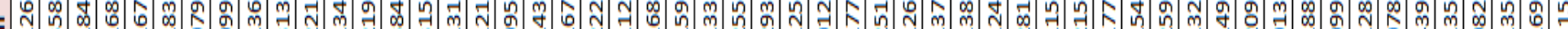

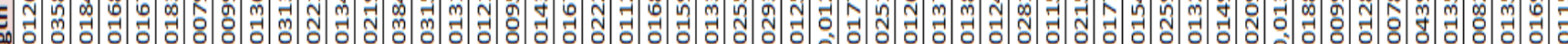
โ

产

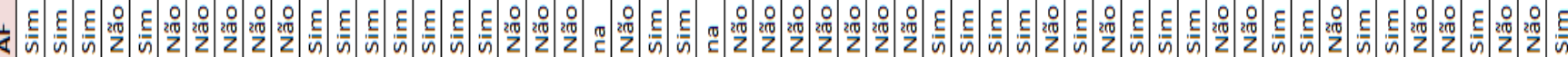

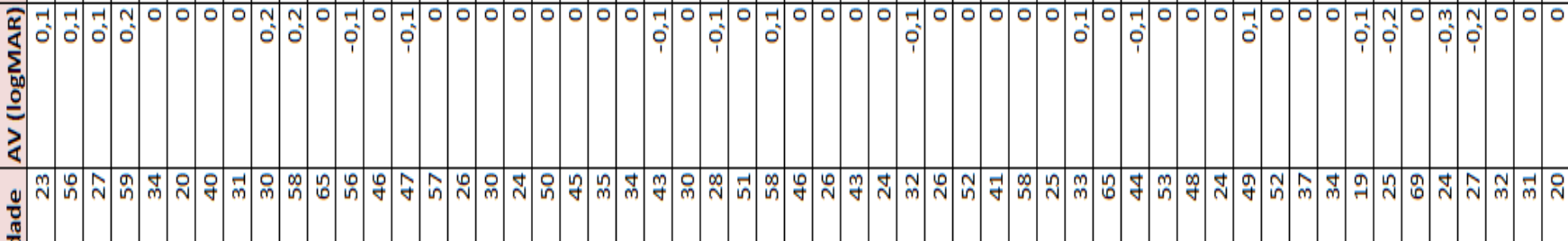

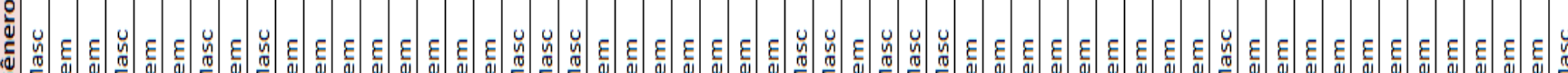

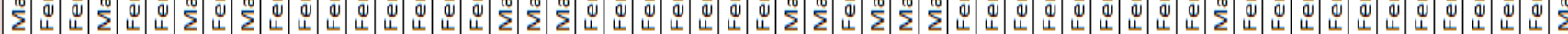

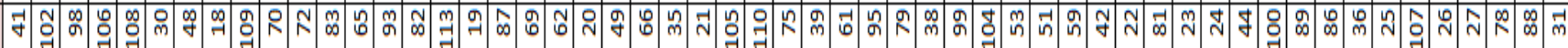

